\title{
ENEOLITHIC, YAMNAYA AND NOUA CULTURE CEMETERIES FROM THE FIRST HALF OF THE 3RD AND THE MIDDLE OF THE 2ND MILLENNIUM BC, POROHY, SITE 3A, YAMPIL REGION, VINNITSA OBLAST: ARCHAEOMETRIC AND CHRONOMETRIC DESCRIPTION, RITUAL AND TAXONOMIC-TOPOGENETIC IDENTIFICATION
}

\begin{abstract}
The paper presents the results of excavations and analytical studies regarding the taxonomic classification of a funeral site associated with the societies of 'barrow cultures' of the north-western Black Sea Coast in the first half of the 3rd and the middle of the 2nd millennium BC. The study discusses the ceremonial centres of the Eneolithic, Yamnaya and Noua cultures.
\end{abstract}

ABSTRACT

Key words: 'barrow cultures', Eneolithic, Early Bronze Age, Late Bronze Age, Middle Dniester Area

The investigations of site 3A in Porohy, Yampil Region, Vinnitsa Oblast, were carried out in 2011 as part of the Polish-Ukrainian research project to investigate the north-western frontier of settlement by 'Early Bronze' culture communities

\footnotetext{
* Department of Archaeology National University of Kyiv-Mohyla Academy, Skovorody 2, 04665 Kyiv, Ukraine; vklochko@ukr.net

** Institute of Prehistory Adam Mickiewicz University; Umultowska 89D, 61-614 Poznań, Poland; antokol@amu.edu.pl

*** Taras Shevchenko University; October 25 128, 3300 Tiraspol, Moldova; razum_22@rambler.ru

**** Institute of Archaeology and Ethnology of Polish Academy of Sciences, Centre for Mountains and Uplands Archaaeology in Kraków; Sławkowska 17, 31-016 Kraków, Poland; wlodarczak.piotr@gmail.com

***** Institute of Prehistory Adam Mickiewicz University; Umultowska 89D, 61-614 Poznań, Poland; danuta@amu.edu.pl
} 


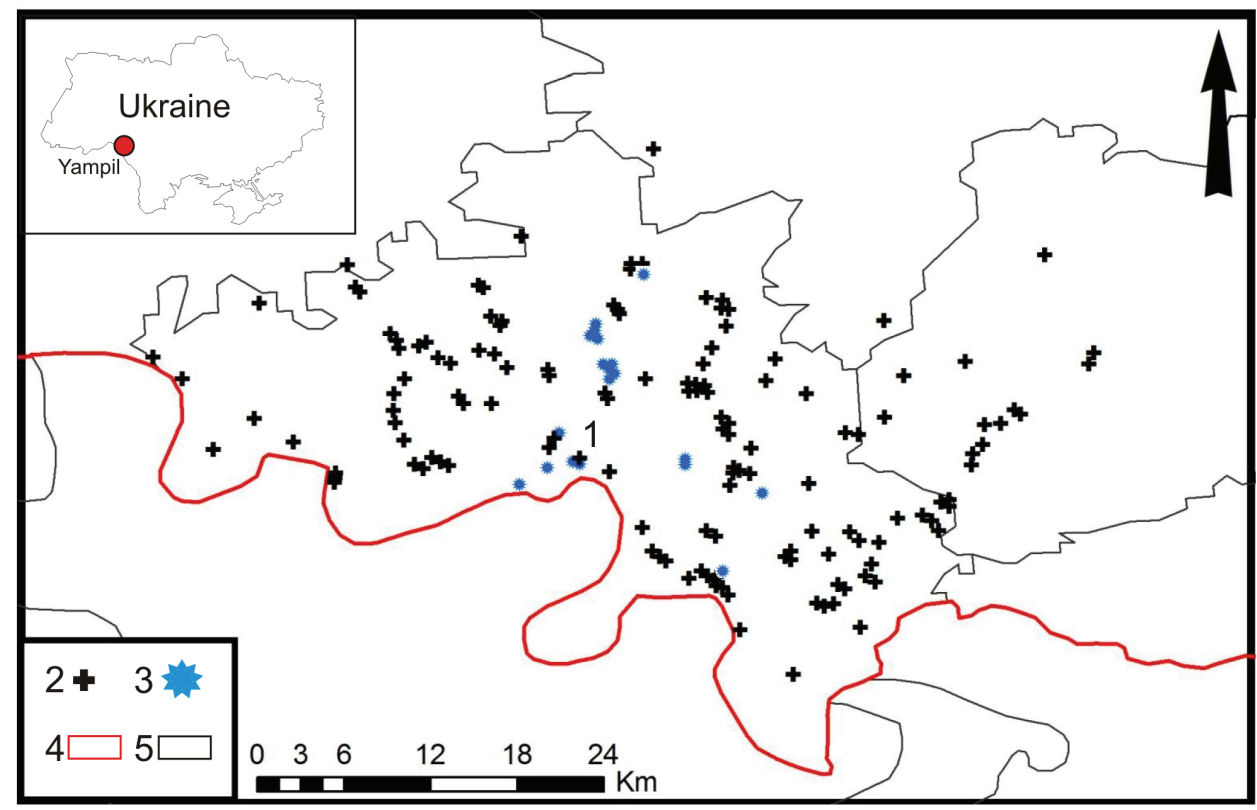

F i g . 1. Map of Yampil Barrow Complex showing administrative borders: 1 - Porohy, barrow 3A; 2 - barrows; 3 - excavated barrows; 4 - Ukrainian-Moldovan frontier; 5 - Yampil Region border. After Jachimowicz 2015, revised

in the Pontic zone by the Institute of Prehistory, Adam Mickiewicz University in Poznań and the Institute of Archaeology, Ukrainian National Academy of Sciences (UNAS) in Kyiv. The project was headed by Prof. Aleksander Kośko, representing the AMU Institute of Prehistory and by Dr. Serhiy M. Razumov representing the UNAS, assisted by Dr. Piotr Włodarczak, representing the Institute of Archaeology and Ethnology of Polish Academy of Sciences, Centre for Mountains and Uplands Archaaeology in Kraków [see Kośko et al. (Eds) 2014].

Investigation results were first made available as an investigation report, satisfying the conservation-archival requirements of the UNAS Institute of Archaeology [Razumov et al. 2012]1. Some results, concerning feature 5, were also published [Razumov et al. 2012a]. This paper, in relation to taxonomy, takes issue with the diagnoses formulated there and presents conclusions drawn by a broader team of experts. The problem of necessary discussions aimed at adjusting the standards of applied systematics of the funeral 'Yampil' determinants of Bronze Age cultures has already been raised in some detail in a paper on the Pidlisivka cemetery [Kośko et al. 2014; Klochko et al. 2015]².

\footnotetext{
1 See also Razumov et al. 2012a.

2 Personal considerations have prevented Dr. Serhiy M. Razumov from taking part in the work of this team of experts.
} 


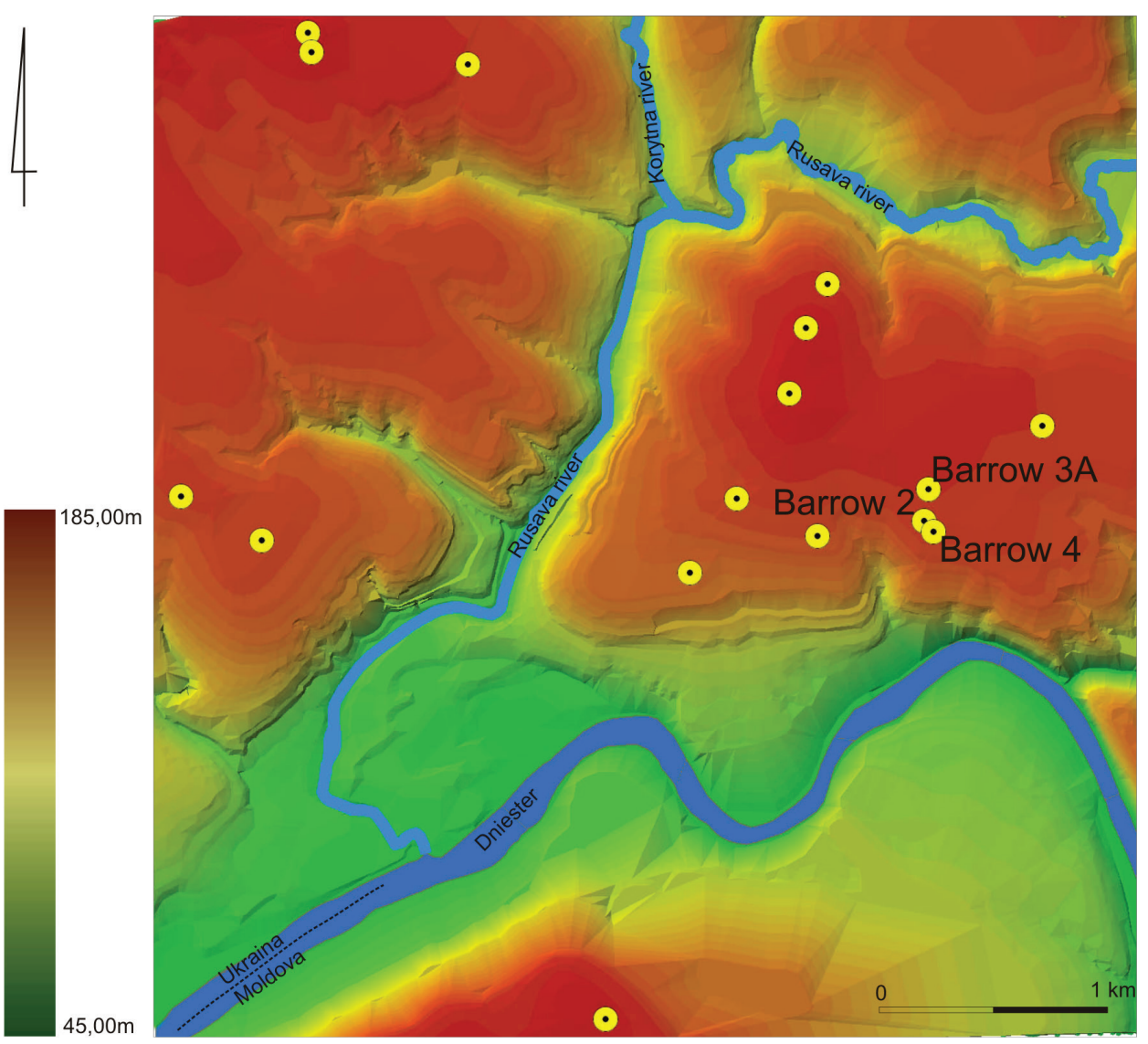

Fig. 2. Porohy, Yampil Region, barrow 3A. Barrow location in the elevation model of the immediate surroundings of the site

1. TOPOGRAPHY OF CEMETERIES AND FIELD INVESTIGATION METHODOLOGY

The site Porohy 3A is situated $4.0 \mathrm{~km}$ east of Yampil, Vinnitsa Oblast (Fig. 1), where a group of five barrows stands in the fields of the agricultural farm 'Porogi'. Local people call the barrows Tsari. They stand close to the road from Yampil to Kryzhopil, in the southern portion of the watershed crest bounded by the valleys of the Dniester and its left-bank tributary - the Rusava (Fig. 2).

In the 1980s, excavations were carried out there by an expedition organized by the Vinnitsa Oblast Museum of Local Lore headed by B. Lobay. The expedition 


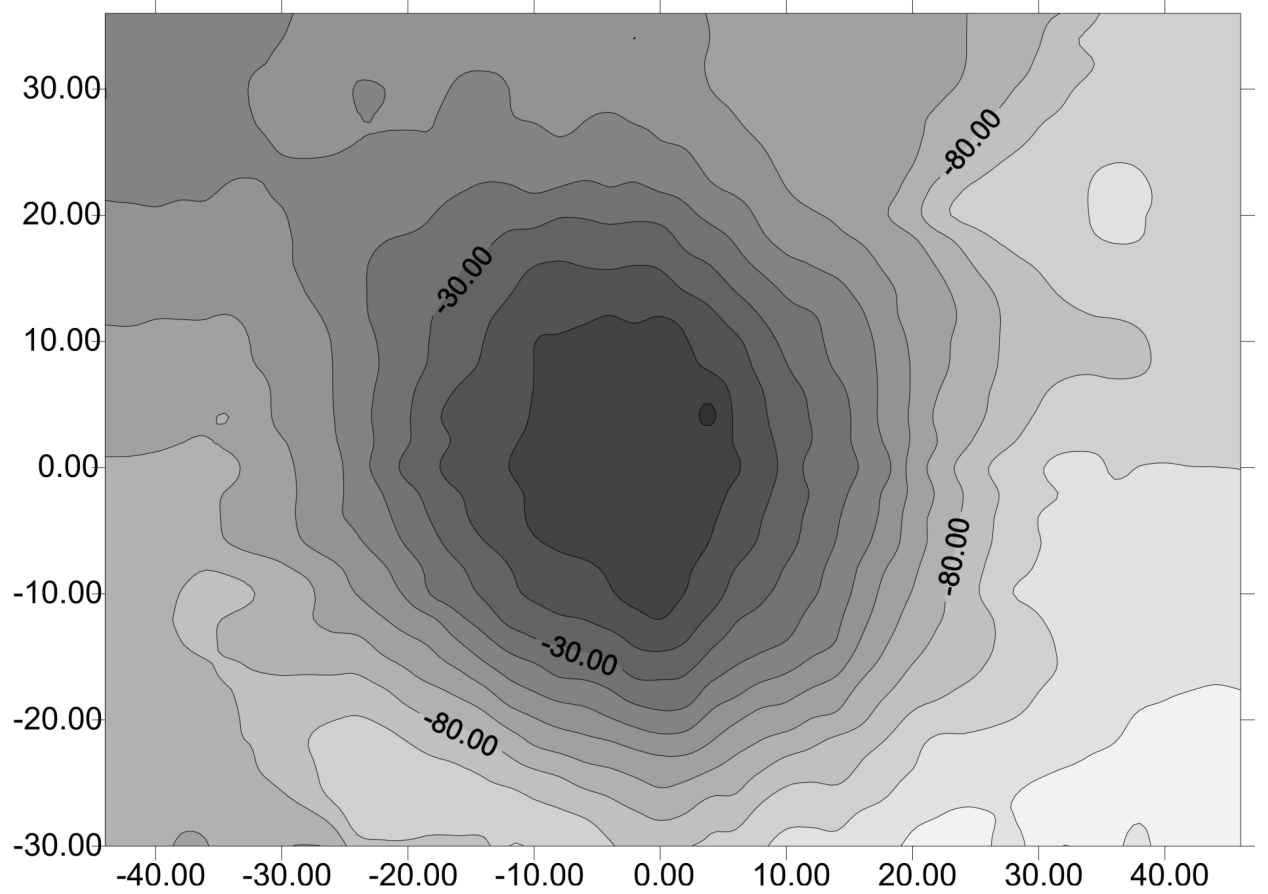

Fi g. 3. Porohy, Yampil Region, barrow 3A. Contour line plan

explored two barrows and in one of them made spectacular discoveries of princely burials from the Sarmatian period [Simonenko, Lobay 1991]. Moreover, it was established that both barrows, and two other features located some distance away but still within the limits of the village of Porohy, had been built by the populations of the Yamnaya culture (YC) in the Early Bronze Age [Harat et al. 2014: 70-85]. Other discoveries included graves with amphorae. Among them, there was a feature holding a vessel characteristic of the circle of the Corded Ware culture (CWC) [Kośko 2011: 188, 192, Fig. 6; Ivanova et al. 2014].

The 2011 excavations employed exploration techniques used already earlier such as digging parallel trenches with mechanical equipment and orienting them W-E. They were 4.0 metres wide and were separated by five baulks to document profiles (the length of the central baulk was $48.0 \mathrm{~m}$ ). In addition, the explored area was expanded in the $\mathrm{N}$ and $\mathrm{S}$ parts in order to capture the outline of the barrow ditch. The mound was explored with arbitrary layers 5-15 $\mathrm{cm}^{\text {thick }}{ }^{3}$.

\footnotetext{
3 For a broader discussion of methodology see Kośko, Razumov 2014.
} 

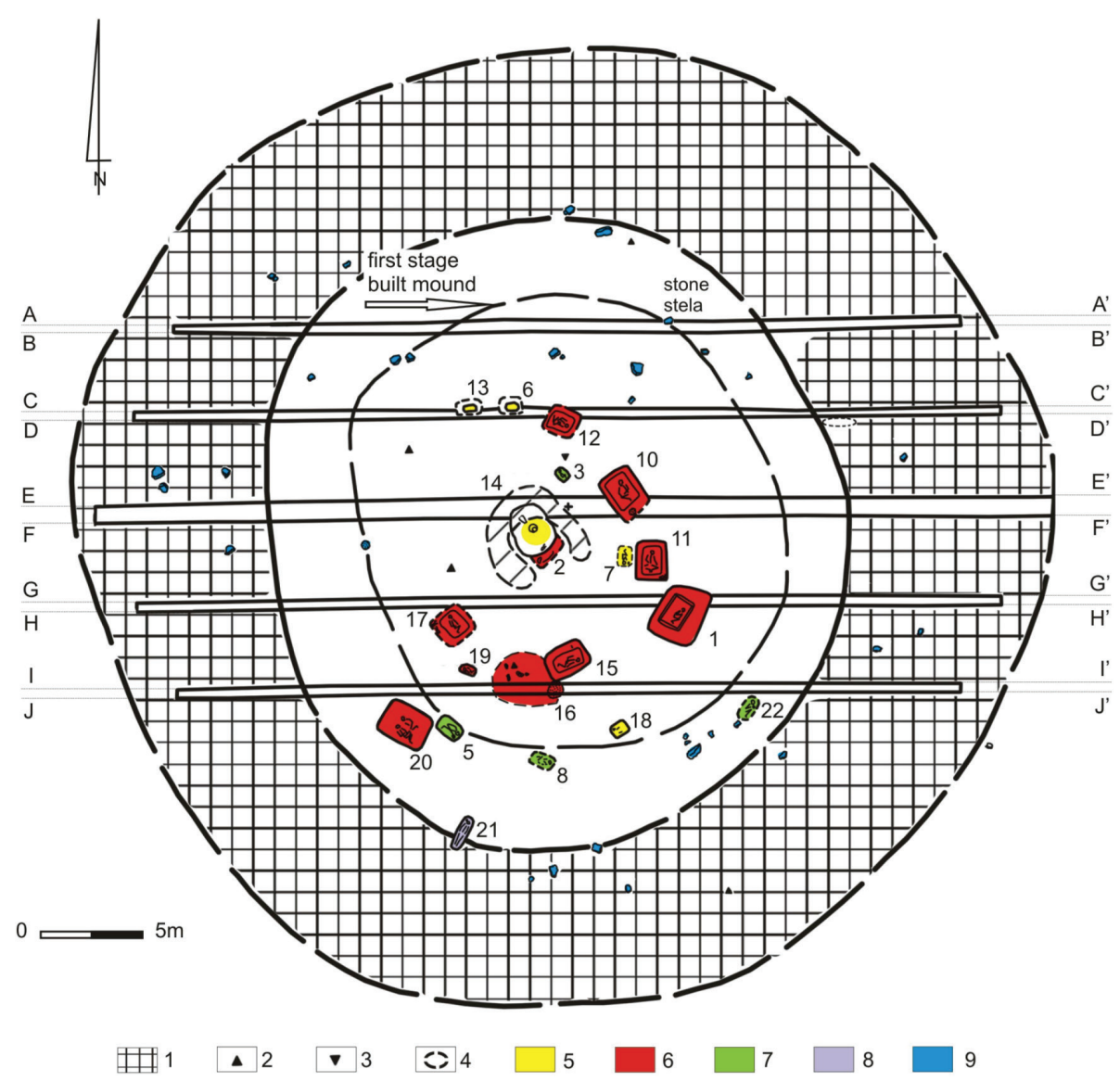

Fig. 4. Porohy, Yampil Region, barrow 3A. Barrow plan: 1 - surrounding ditch; 2 - animal bones; 3 - pottery shards; 4 - vessel fragments; 5 - features associated with the Eneolithic; 6 - features associated with the Yamnaya culture; 7 - features linked with Noua culture; 8 - features linked with Iron Age; 9 - elements of barrow cromlech

2. BARROW DESCRIPTION: MOUND MORPHOMETRY AND STRATIGRAPHY, SCATTER PATTERN AND STRUCTURE OF GRAVE FEATURES

At the time of commencing the excavations, the barrow was already badly damaged by ploughing and by an attempt to level it off using a bulldozer. The barrow was about $40.0 \mathrm{~m}$ in diameter and 1.1-1.2 $\mathrm{m}$ high (Figs. 3, 4). The extensive barrow destruction took place after the Second World War, as a 1933 map shows its height to be $3.6 \mathrm{~m}$. 


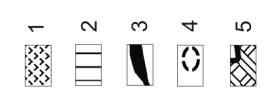

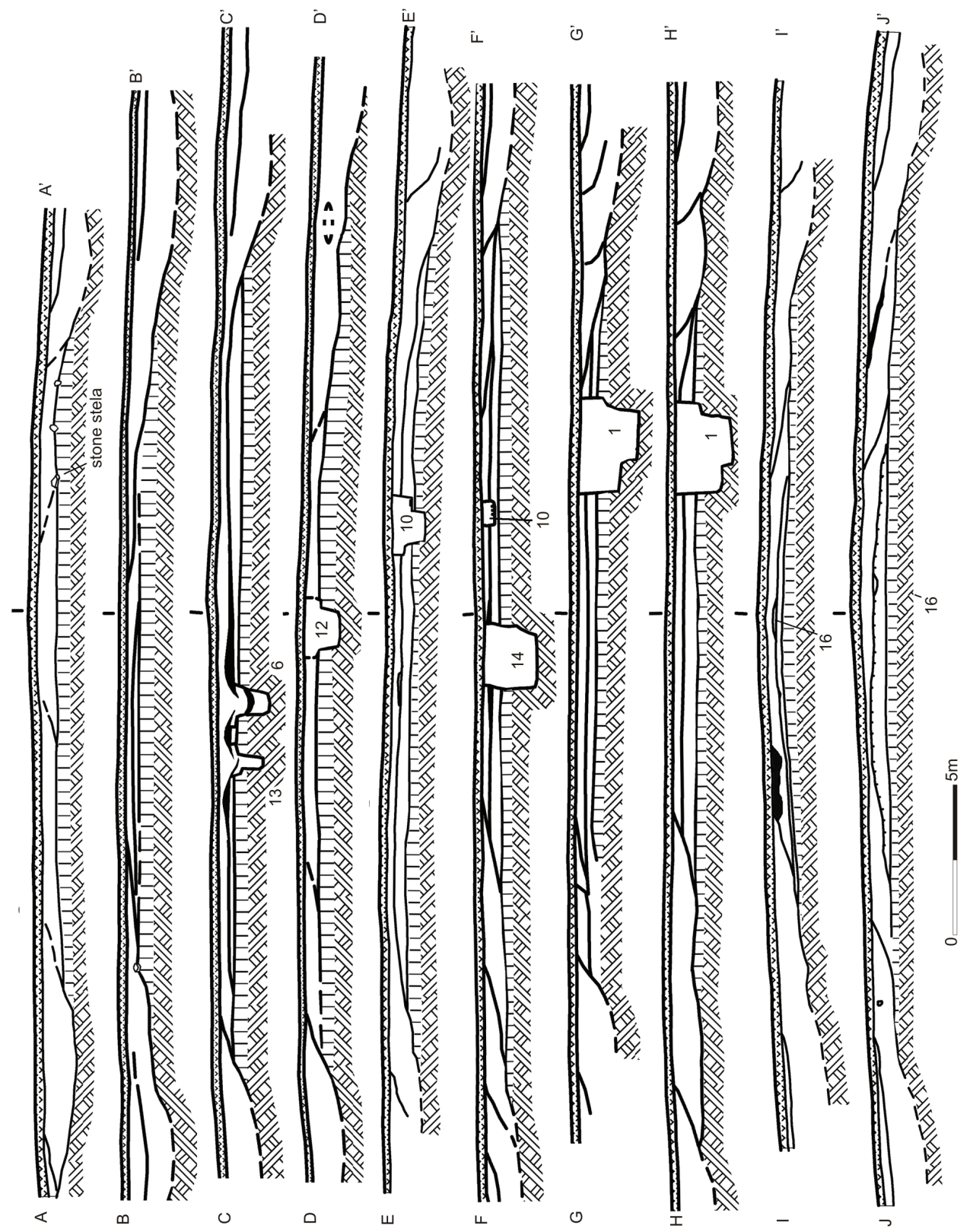

Fi g. 5. Porohy, Yampil Region, barrow 3A. Barrow profiles: 1 - surface soil; 2 - layer under the barrow mound; 3 - sterile soil dug from the pit; 4 - ceramic vessel fragments; 5 - sterile soil 

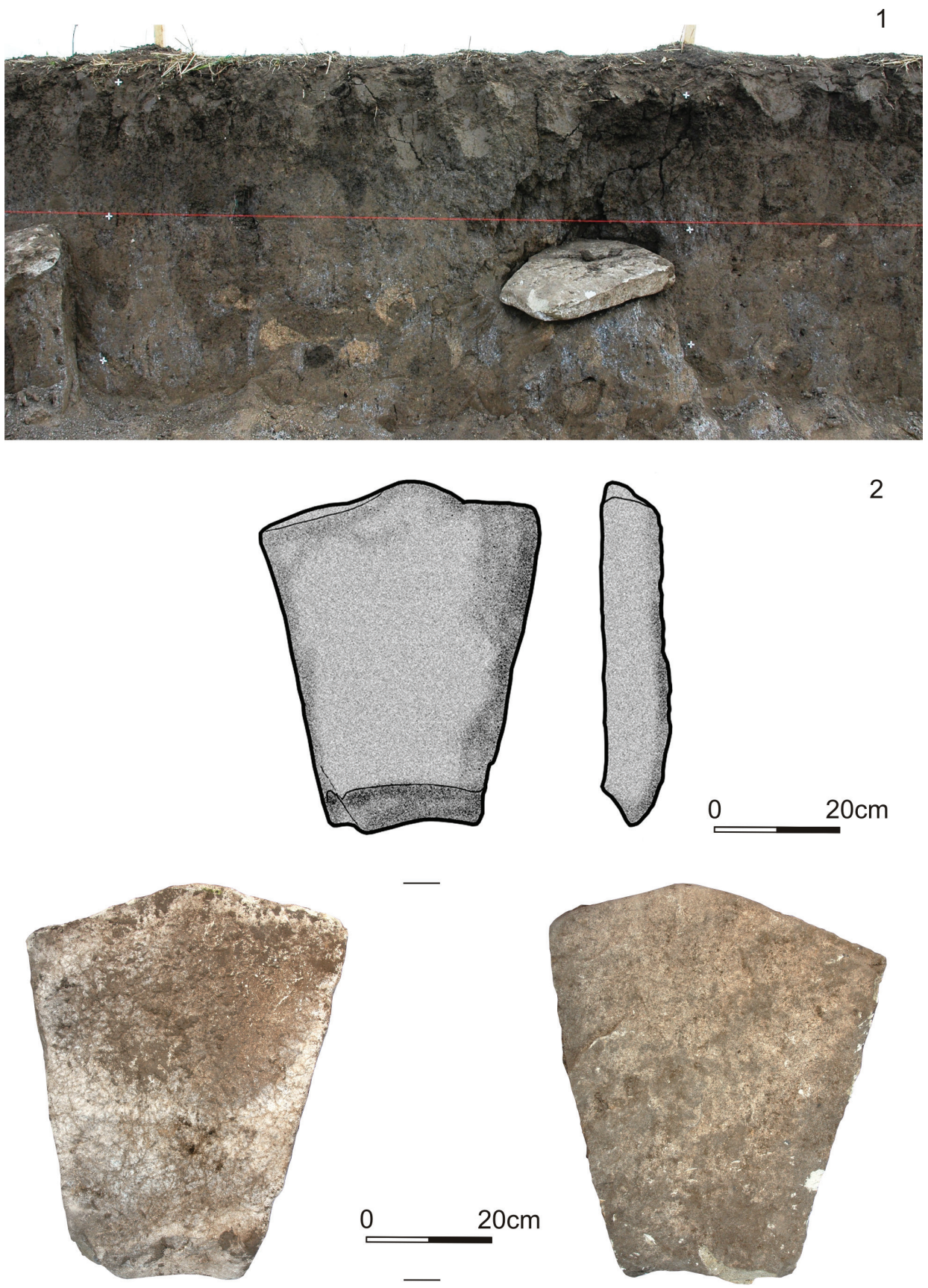

Fig. 6. Porohy, Yampil Region, barrow 3A. Stela: 1 - location in situ (see Fig. 4); 2 - drawing and photo the relic 
The study of the vertical cross-sections of the barrow helped distinguish two separate mounds: an older, Eneolithic (?) and a younger, YC. Moreover, local addons, resulting from the sinking of successive Early Bronze graves were poorly visible. Its final form, the barrow reached still in the Early Bronze Age. Later, around the middle of the 2 nd millennium BC and in the early modern era, it was re-used to sink another four graves.

Vertical observations were hampered by numerous animal burrows. So strong a deformation of cultural strata due to the action of animals and plants finds no analogy in the investigations by the present authors on the Polish Lowland. It suggests that these barrows constituted special loci where biological activity was concentrated [Sudnik-Wójcikowska et al. 2013].

Along its entire circumference, the barrow was surrounded by a ditch up to $10.0 \mathrm{~m}$ wide and $0.5 \mathrm{~m}$ deep, measuring from the original level. In the mound strata, flint artefacts were discovered (dated mainly to the Upper Palaeolithic), accompanied by single shards of hand-made pottery (dated to the Eneolithic-Early Bronze Age) and the shards of wheel-thrown pottery, originating from the Iron Age - the Roman period.

In the course of the investigations, 20 features were exposed: four Eneolithic or from the beginnings of the Early Bronze Age (?), ten YC, five Noua culture (NC) and one from the Middle Sarmatian period (Figs. 4, 5). Due to the advanced destruction of the mound caused by tillage, it is difficult to relate individual graves to barrow construction phases. It was possible to distinguish two major phases and cases of local add-ons.

In its oldest phase, the barrow was encircled with a stone cromlech. The structure was badly damaged at subsequent barrow extensions. In the $\mathrm{N}$ part, on the edge of the older mound, an overturned stone stela was exposed (Fig. 6).

All the anthropological data included in the descriptions below come from the separate publication [Litvinova et al. 2015], while in the case of archaeozoological data, the assessments by Y.Y Yanish [see Razumov et al. 2012] have been used.

Feature 3A/1

\begin{tabular}{|c|c|c|c|}
\hline Culture & \multicolumn{3}{|l|}{ Yamnaya } \\
\hline Dating & \multicolumn{3}{|c|}{$\begin{array}{l}\text { Ki-17384: } 3770 \pm 170 \mathrm{BP} \\
\text { Ki-17437: } 4430 \pm 70 \mathrm{BP} ; \mathrm{Poz}-70668: 3760 \pm 35 \mathrm{BP} \text { (human bones) }\end{array}$} \\
\hline \multicolumn{2}{|l|}{ Grave pit } & \multicolumn{2}{|l|}{ Burial } \\
\hline Structure type & Pit & Sex & Male \\
\hline Number of burials & 1 & Age & $30-35$ years \\
\hline $\begin{array}{l}\text { Size at the level } \\
\text { of discovery }\end{array}$ & $2.7 \times 2.55 \mathrm{~m}$ & Orientation & NE-SW \\
\hline $\begin{array}{l}\text { Size at the level } \\
\text { of the bottom }\end{array}$ & $1.85 \times 1.35 \mathrm{~m}$ & Deviation & $16^{\circ} \mathrm{N}$ \\
\hline Depth & $2.15 \mathrm{~m}$ & Arrangement of head & $\mathrm{L}$ \\
\hline
\end{tabular}




\begin{tabular}{|l|l|l|l|}
\hline Pit orientation & NE-SW & Arrangement of trunk & L \\
\hline Deviation & $18^{\circ} \mathrm{N}$ & Upper limbs & A \\
\hline $\begin{array}{l}\text { Distance from barrow } \\
\text { centre }\end{array}$ & $8.52 \mathrm{~m}$ & Lower limbs & $1 / 2$ \\
\hline Azimuth & $120^{\circ}$ & Ochre & + \\
\hline Wooden roofing & + & Presence of mat & + \\
\hline $\begin{array}{l}\text { Roofing element } \\
\text { orientation }\end{array}$ & Perpendicular & Animal bones & - \\
\hline $\begin{array}{l}\text { Other structural } \\
\text { elements }\end{array}$ & Wall boarding & Ritual objects & 1 flint flake, ochre lump \\
\hline Comments & \multicolumn{2}{|l}{} \\
\hline
\end{tabular}

The grave was sunk into the youngest barrow mound. Its outline was recorded immediately below the surface soil $(0.3 \mathrm{~m})$ and its fill was heterogeneous: it consisted of yellow loess and dark humus earth. The pit structure was complex. On the SE side, there was a step $0.8 \mathrm{~m}$ wide, leading to a regularly rectangular grave chamber. On the other sides, considerably higher, there were narrower steps supporting a wooden roofing placed perpendicularly to the longer axis of the pit. On the pit circumference, the remains of boards were recorded, which once formed a chest structure $0.6 \mathrm{~m}$ high and $4-5 \mathrm{~cm}$ thick. The boards were secured in grooves 3-5 $\mathrm{cm}$ deep.

On the pit bottom, the skeleton of an adult male lay crouched on the left side. The bones bore traces of colouring with ochre. The frontal bone showed obliterated traces of injuries. On the parietal and occipital bones, and on the mandible, traces of injuries were recorded left by intentional manipulations [Lytvinova et al. 2015]. About $0.4 \mathrm{~m} \mathrm{E}$ of the head, a lump of ochre, and underneath the right wrist bones, a flint flake were found (Figs. 7-9).

Grave goods

1. Oval lump of ochre about $6 \mathrm{~cm}$ in diameter.

2. Flint flake (Fig. 7: 1). 


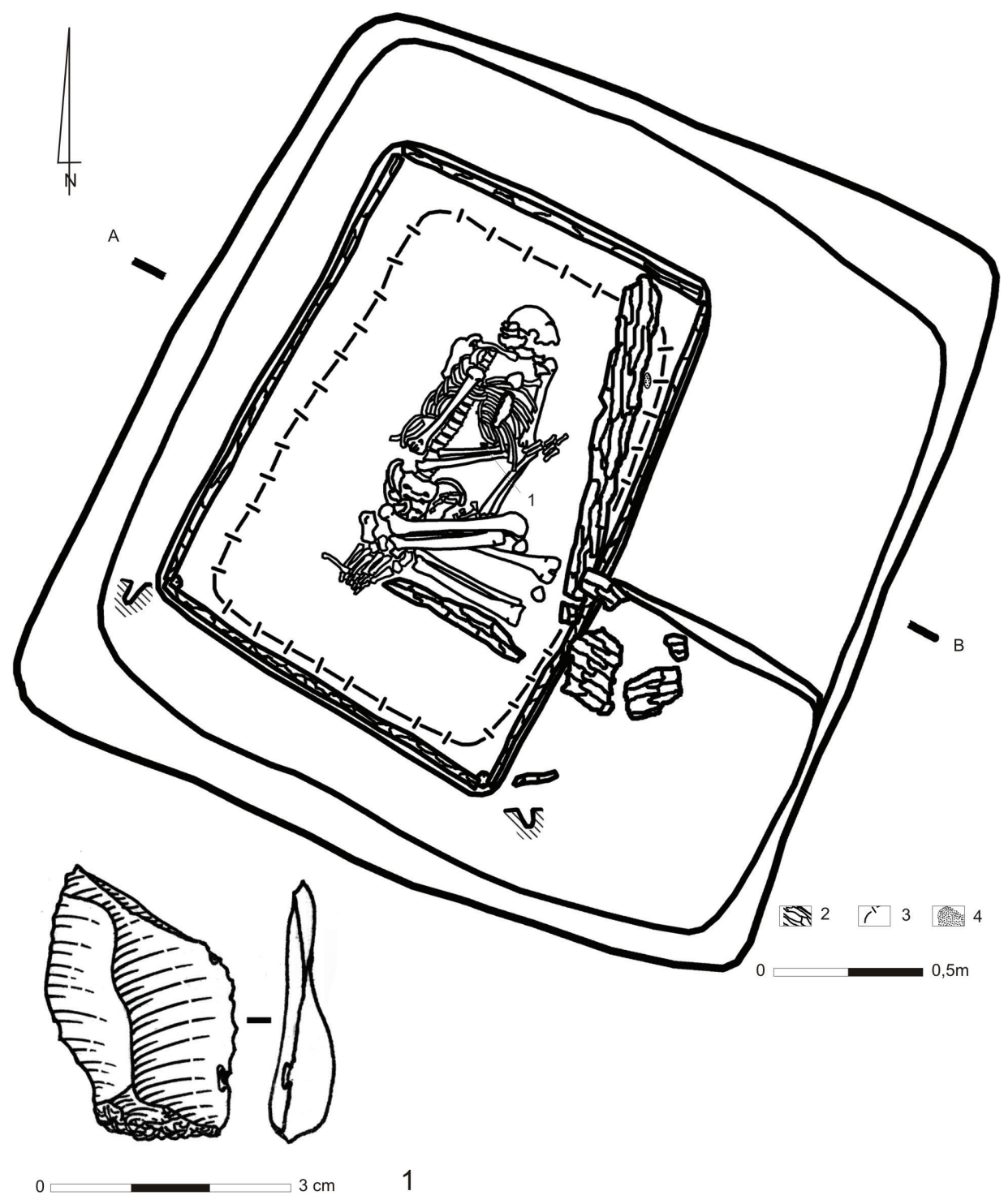

Fig . 7. Porohy, Yampil Region, barrow 3A. Feature 3A/1: 1 - flint flake; 2 - wood remains; 3 outline of mat; 4 - ochre 


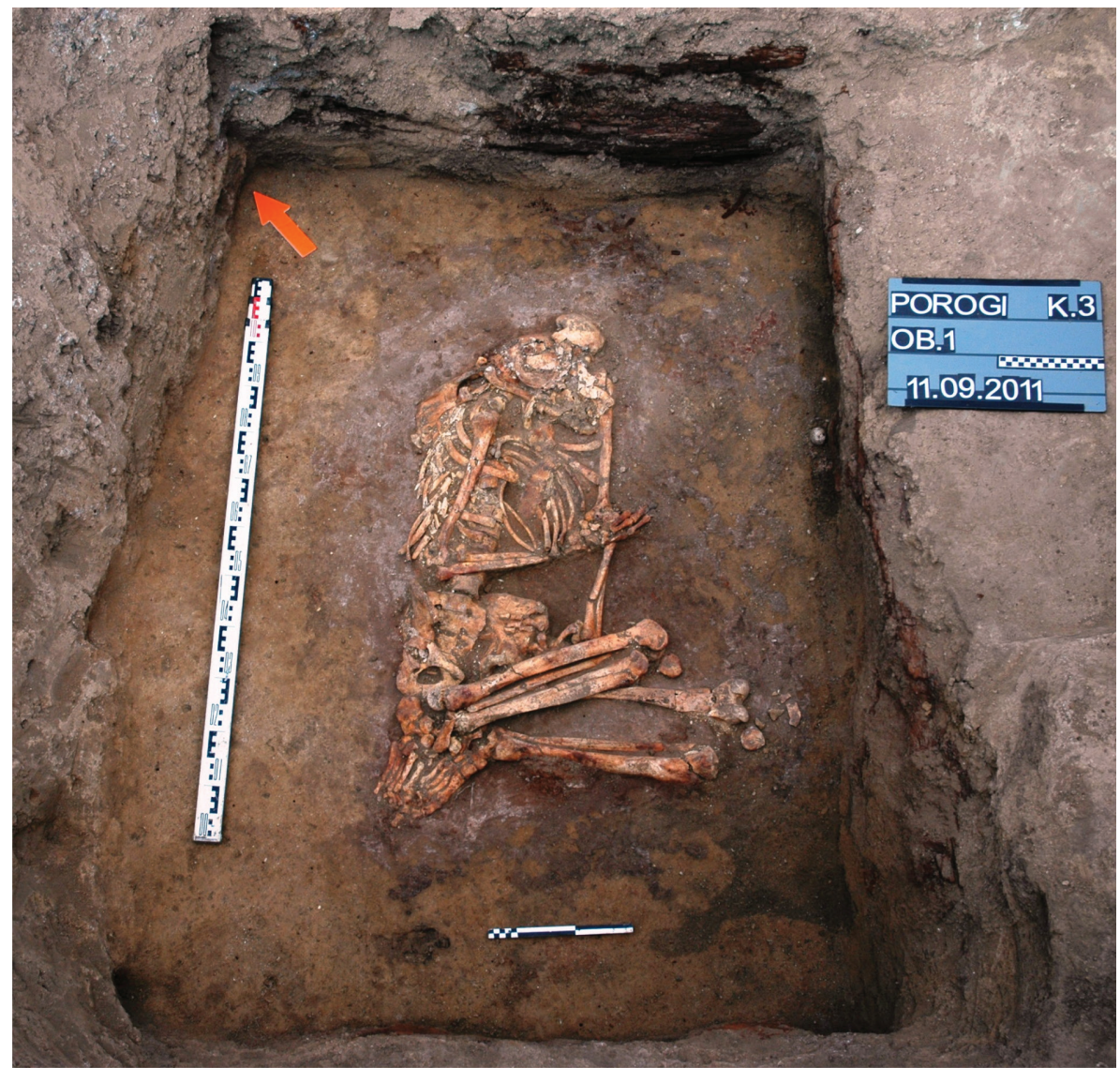

Fig . 8. Porohy, Yampil Region, barrow 3A. Feature 3A/1 

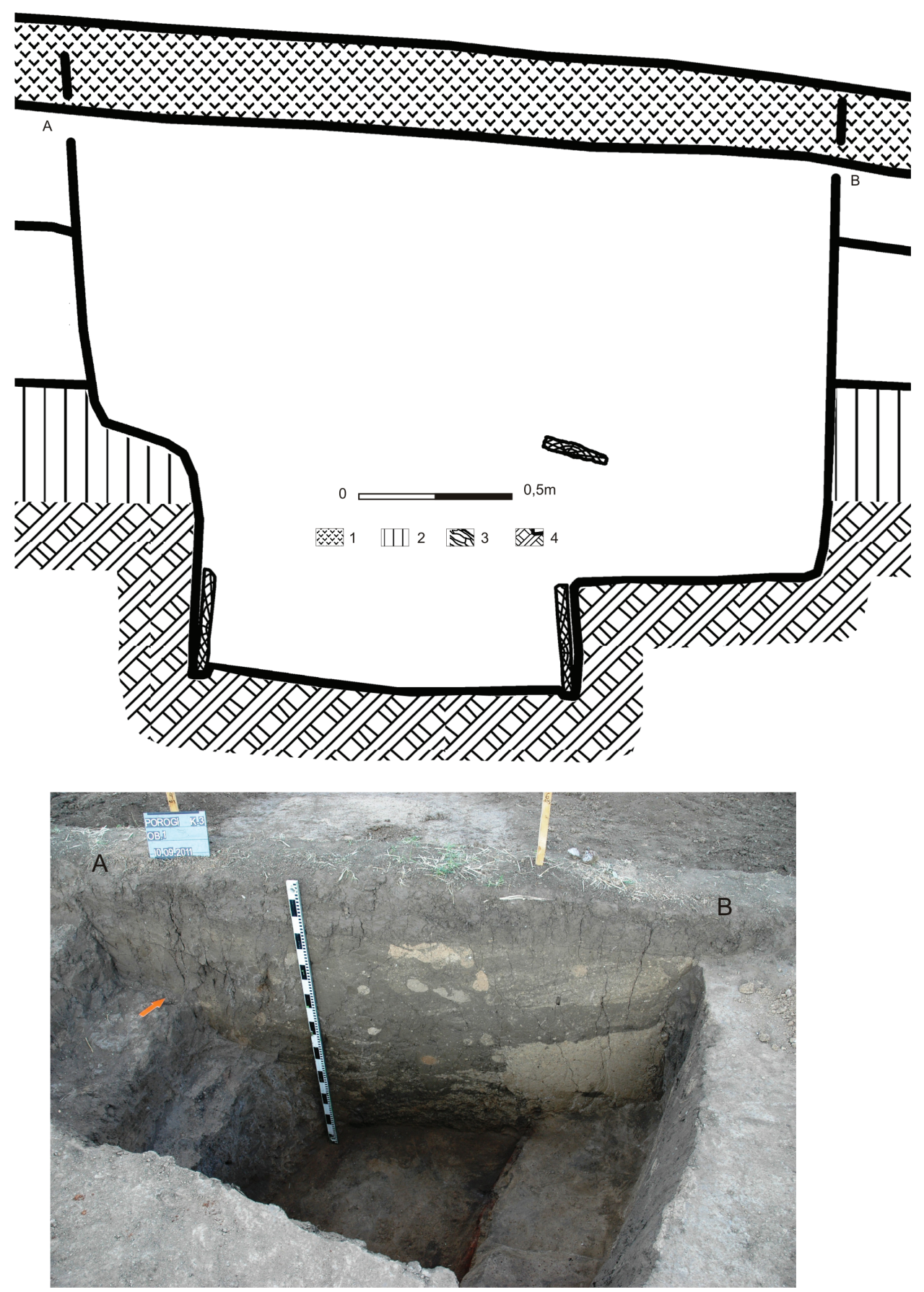

Fig. 9. Porohy, Yampil Region, barrow 3A. Profile of feature 3A/1: 1 - surface soil; 2 - layer under the barrow mound; 3 - wood remains; 4 - sterile soil 
Feature 3A/2

\begin{tabular}{|c|c|c|c|}
\hline Culture & \multicolumn{3}{|c|}{ Yamnaya (?) } \\
\hline Dating & \multicolumn{3}{|c|}{ Poz-74392: 4140 $\pm 35 \mathrm{BP} ; \mathrm{Ki}-18927: 2980 \pm 90 \mathrm{BP}$ (human bones) } \\
\hline \multicolumn{2}{|l|}{ Grave pit } & \multicolumn{2}{|l|}{ Burial } \\
\hline Structure type & Pit & Sex & Male? \\
\hline Number of burials & 1 & Age & Maturus \\
\hline $\begin{array}{l}\text { Size at the level } \\
\text { of discovery }\end{array}$ & $?$ & Orientation & SW-NE \\
\hline $\begin{array}{l}\text { Size at the level } \\
\text { of the bottom }\end{array}$ & $1.70 \times ? \mathrm{~m}$ & Deviation & $?$ \\
\hline Depth & $0.5 \mathrm{~m}$ & Arrangement of head & $?$ \\
\hline Pit orientation & SW-NE & Arrangement of trunk & Supine? \\
\hline Deviation & & Upper limbs & $?$ \\
\hline $\begin{array}{l}\text { Distance from barrow } \\
\text { centre }\end{array}$ & $1.7 \mathrm{~m}$ & Lower limbs & $?$ \\
\hline Azimuth & $152^{\circ}$ & Ochre & + \\
\hline Wooden roofing & & Presence of mat & + \\
\hline $\begin{array}{l}\text { Roofing element } \\
\text { orientation }\end{array}$ & $?$ & Animal bones & - \\
\hline $\begin{array}{l}\text { Other structural } \\
\text { elements }\end{array}$ & - & Ritual objects & - \\
\hline Comments & & & \\
\hline
\end{tabular}

The feature was sunk into the central portion of the mound and to a large extent was damaged by a robber trench (feature $3 \mathrm{~A} / 14$ ). Its outline was barely visible. In situ, there lay only bones of the right upper limb, the scapula and skull fragments. These remains bore traces of colouring with ochre. Immediately underneath the skull, a large stone slab $(0.4 \times 0.3 \times 0.1 \mathrm{~m})$ was unearthed; it could have been a cover element of older grave 14 (Figs. 10, 13). 


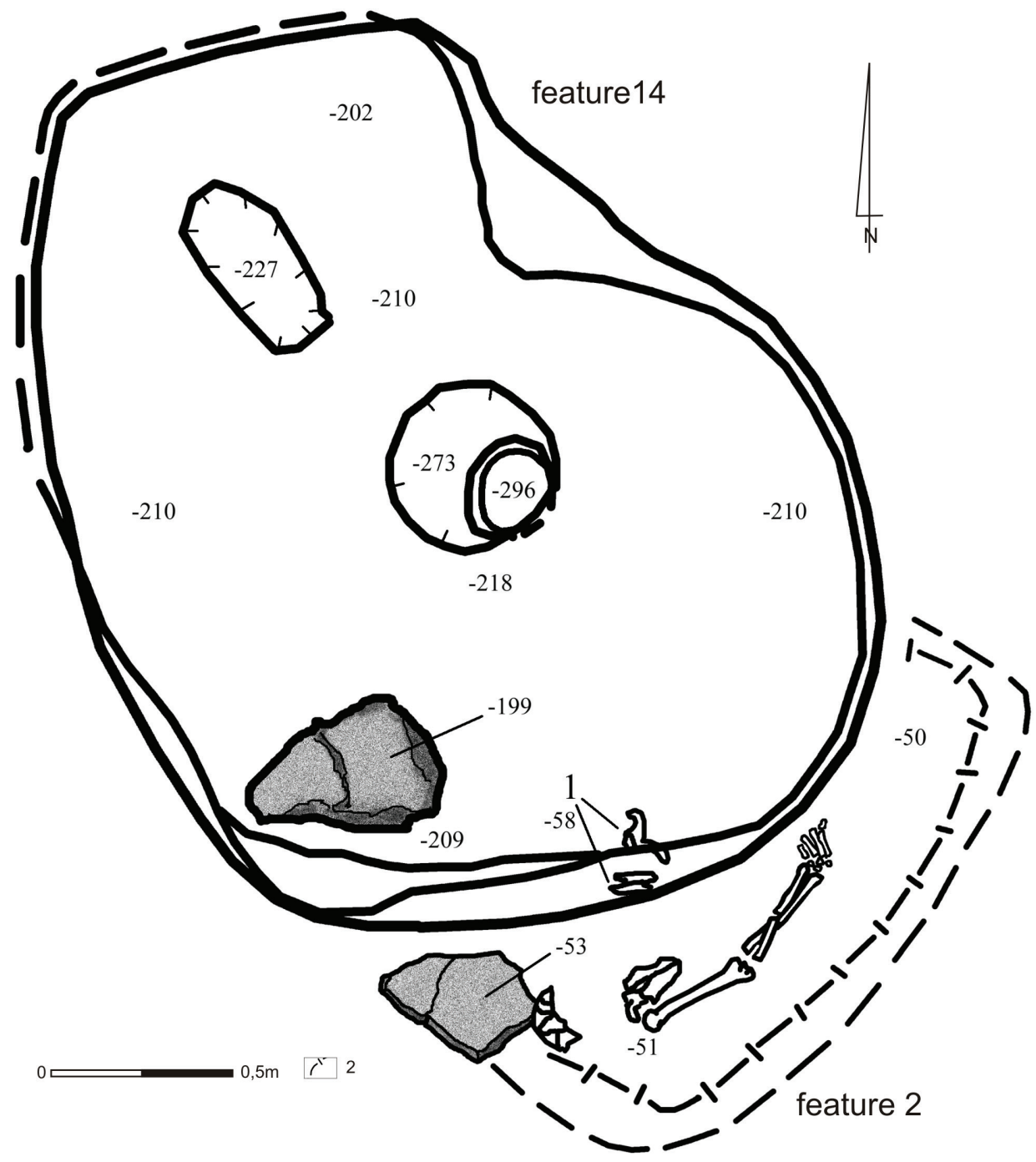

Fig. 10 . Porohy, Yampil Region, barrow 3A. Plan of features 3A/2 and 3A/14: 1 - fragments of a tool from red-deer antler; 2 - outline of mat 

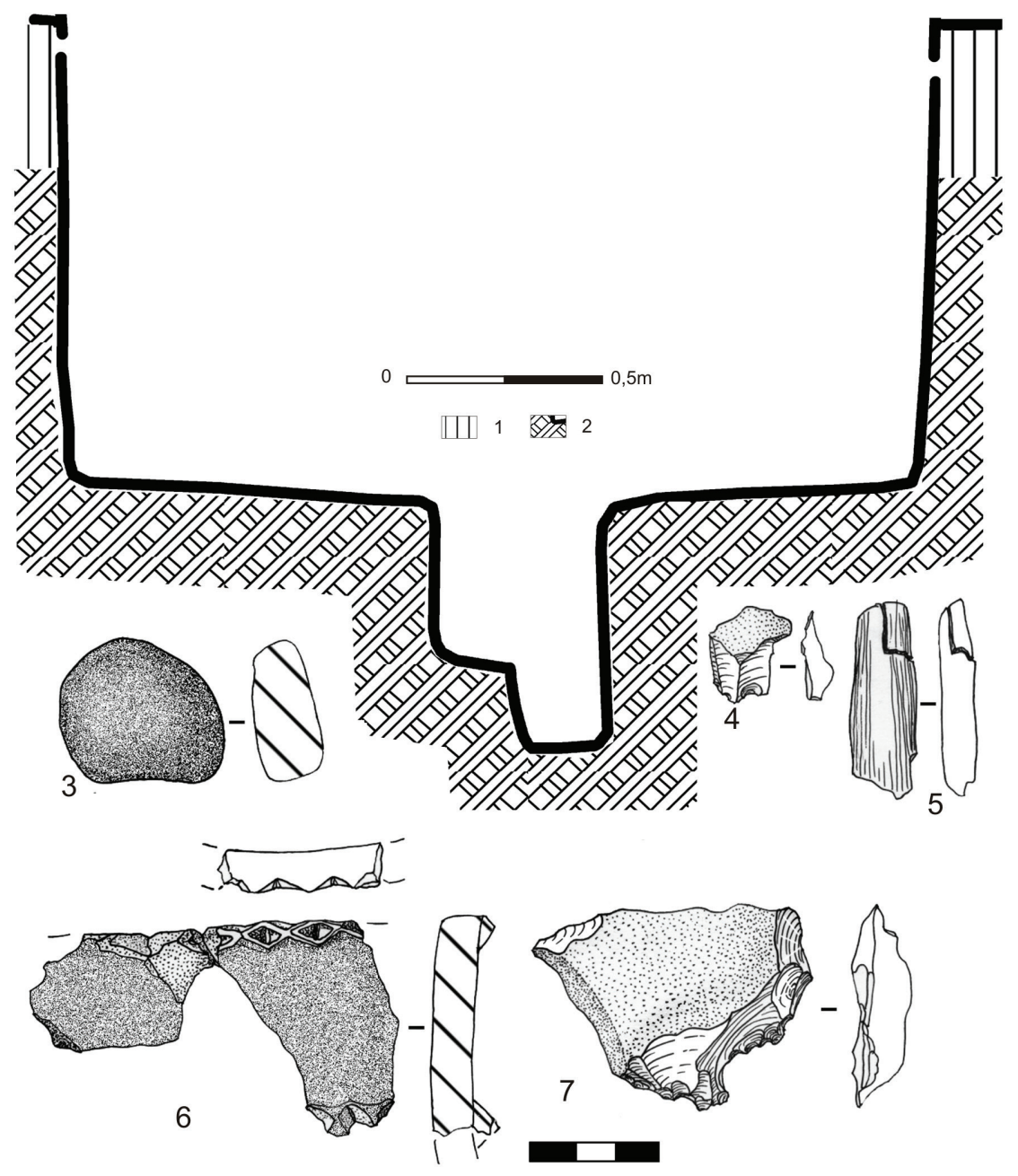

Fig. 11 . Porohy, Yampil Region, barrow 3A. Profile of feature 3A/14: 1 - layer under the barrow mound; 2 - sterile soil. Objects from the feature fill; 3 - pebble with traces of use; 4, 7 - flint flakes; 5 - fragment of a tool from red-deer antler; 6 - fragments of a vessel rim 


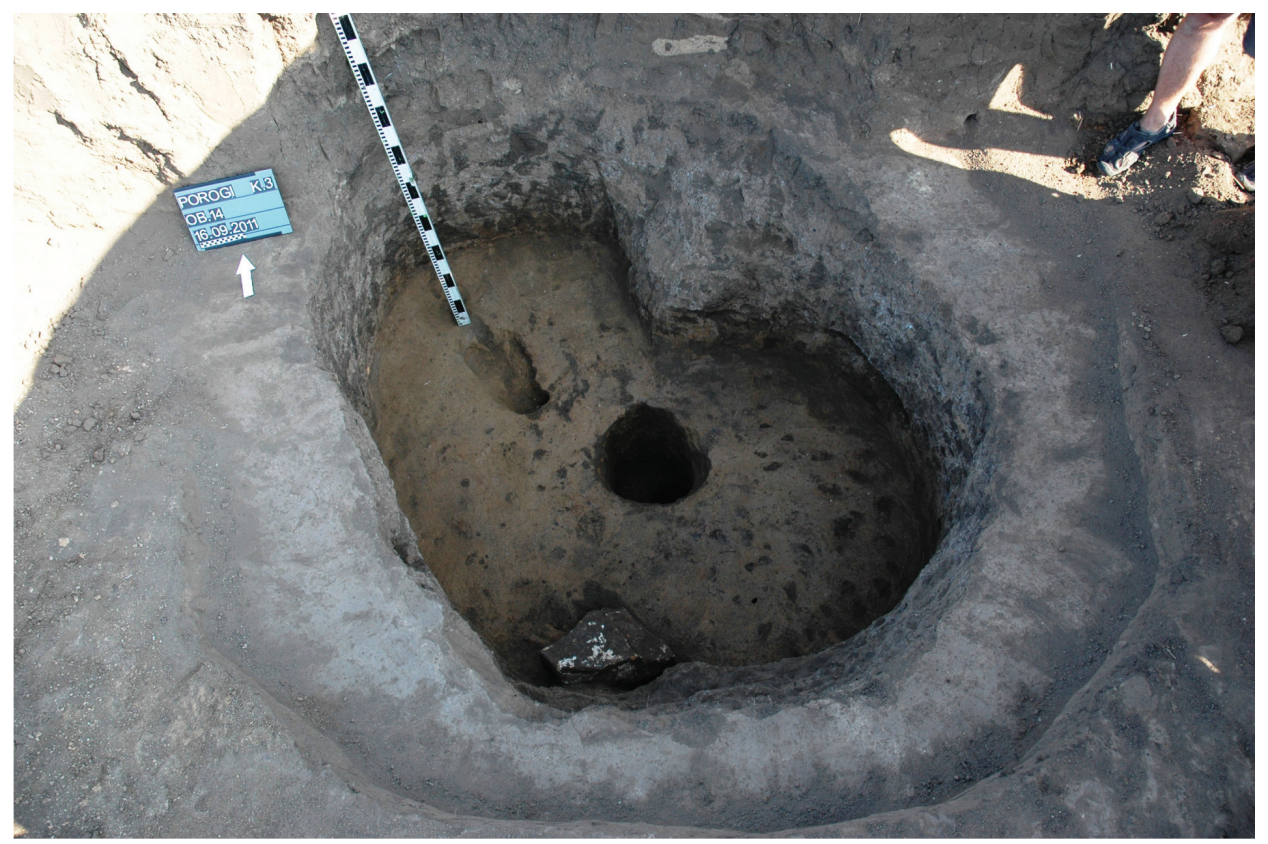

Fig. 12 . Porohy, Yampil Region, barrow 3A. Plan of feature 3A/14

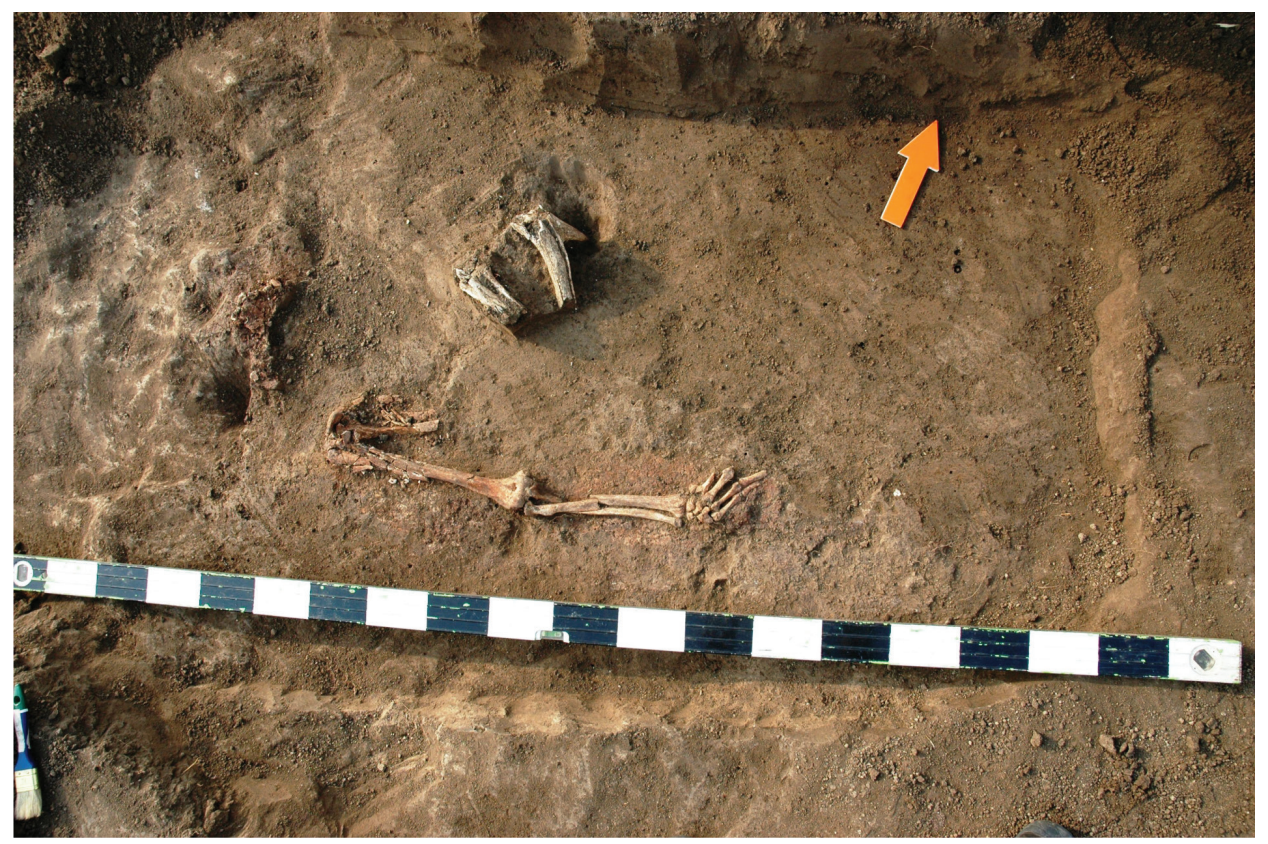

Fi g . 13. Porohy, Yampil Region, barrow 3A. Plan of feature 3A/2 
Feature 3A/3

\begin{tabular}{|l|l|l|l|}
\hline Culture & \multicolumn{2}{|l|}{ Noua } \\
\hline Dating & \multicolumn{2}{l|}{ Burial } \\
\hline Grave pit & Pit? & Sex & $?$ \\
\hline Structure type & 1 & Age & Below 3 years \\
\hline Number of burials & ? & Orientation & NW-SE \\
\hline $\begin{array}{l}\text { Size at the level } \\
\text { of discovery }\end{array}$ & $?$ & Deviation & $12^{\circ}$ E \\
\hline $\begin{array}{l}\text { Size at the level } \\
\text { of the bottom }\end{array}$ & $\begin{array}{l}\text { Approx. } 0.70 \times \\
0.50 \mathrm{~m}\end{array}$ & Arrangement of head & L? \\
\hline Depth & $0.6 \mathrm{~m}$ & Arrangement of trunk & L \\
\hline Pit orientation & NW-SE & Upper limbs & $?$ \\
\hline Deviation & $7^{\circ}$ W & Lower limbs & 2 \\
\hline $\begin{array}{l}\text { Distance from barrow } \\
\text { centre }\end{array}$ & $2.97 \mathrm{~m}$ & Ochre & + \\
\hline Azimuth & $148^{\circ}$ & Presence of mat & + \\
\hline Wooden roofing & + & Animal bones & - \\
\hline $\begin{array}{l}\text { Roofing element } \\
\text { orientation }\end{array}$ & Perpendicular & Ritual objects & - \\
\hline $\begin{array}{l}\text { Other structural } \\
\text { elements }\end{array}$ & - & \multicolumn{2}{l|}{} \\
\hline Comments & & & \\
\hline
\end{tabular}

The grave was sunk into the central portion of the mound. Immediately beneath surface soil, the fragments of wooden planks up to $20 \mathrm{~cm}$ wide, $75 \mathrm{~cm}$ long and $4 \mathrm{~cm}$ thick were discovered. They were elements of a roofing. The pit outline was barely visible against mound strata. Judging by the shape of the mat, it can be assumed to have been rectangular. A child skeleton lay crouched on the left side about $0.20 \mathrm{~m}$ below a wooden cover. The bones bore traces of slight colouring with ochre (Fig. 14). 

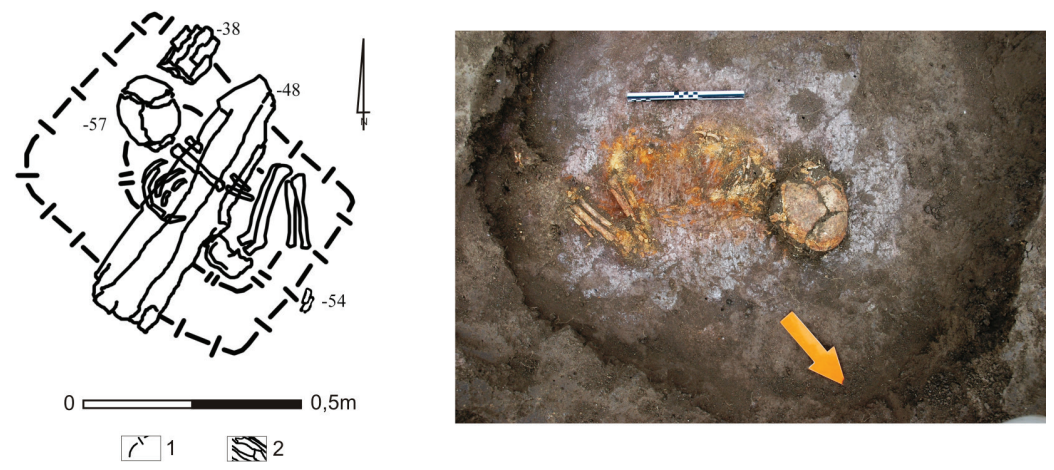

Fi g. 14. Porohy, Yampil Region, barrow 3A. Plan of feature 3A/3. 1 - outline of mat; 2 - wood remains

Feature $3 A / 5$

\begin{tabular}{|c|c|c|c|}
\hline Culture & \multicolumn{3}{|l|}{ Noua } \\
\hline Dating & \multicolumn{3}{|c|}{ Ki-17440: $3200 \pm 90 \mathrm{BP}$ (human bone) } \\
\hline \multicolumn{2}{|l|}{ Grave pit } & \multicolumn{2}{|l|}{ Burial } \\
\hline Structure type & Pit & Sex & Male \\
\hline Number of burials & 1 & Age & $25-30$ years \\
\hline $\begin{array}{l}\text { Size at the level } \\
\text { of discovery }\end{array}$ & $?$ & Orientation & E-W \\
\hline $\begin{array}{l}\text { Size at the level } \\
\text { of the bottom }\end{array}$ & $1.5 \times 0.75 \mathrm{~m}$ & Deviation & $0^{\circ} \mathrm{E}$ \\
\hline Depth & $0.85 \mathrm{~m}$ & Arrangement of head & $\mathrm{L}$ \\
\hline Pit orientation & E-W & Arrangement of trunk & $\mathrm{L}$ \\
\hline Deviation & $0^{\circ}$ & Upper limbs & $\mathrm{D}$ \\
\hline $\begin{array}{l}\text { Distance from } \\
\text { barrow centre }\end{array}$ & $10.78 \mathrm{~m}$ & Lower limbs & 1 \\
\hline Azimuth & $203^{\circ}$ & Ochre & - \\
\hline Wooden roofing & Present & Presence of mat & + \\
\hline $\begin{array}{l}\text { Roofing element } \\
\text { orientation }\end{array}$ & Longitudinal & Animal bones & $\begin{array}{l}8 \text { fragments of horse bones: sacral } \\
\text { bone, two caudal vertebrae }\end{array}$ \\
\hline $\begin{array}{l}\text { Other structural } \\
\text { elements }\end{array}$ & - & Ritual objects & Vessel \\
\hline Comments & & & \\
\hline
\end{tabular}

The grave was sunk into the southern edge of the mound. It was regularly rectangular in shape and its fill was found to contain the fragments of wooden roofing elements, up to $0.15 \mathrm{~m}$ wide. On the bottom, there lay the skeleton of an adult male 
crouched on its left side. At the chest, next to the hand bones, a clay vessel and several fragments of the spine of a young, domesticated horse were found (Fig. 15).

Grave goods

1. A mug with a tall cylindrical neck and a slightly flared rim ending in an obliquely cut edge. Flat bottom. Coil handle. The outer surface is even, smoothed, black and brown-yellow in colour. The body contains temper of crushed ceramics. Dimensions: height $-11 \mathrm{~cm}$, mouth diameter $-10.5 \mathrm{~cm}$, belly diameter $-13 \mathrm{~cm}$, bottom diameter $-6.8 \mathrm{~cm}$ (Fig. 16).

2. Six fragments of the sacral bone and two caudal vertebrae of a young domesticated horse (Fig. 15: 2).

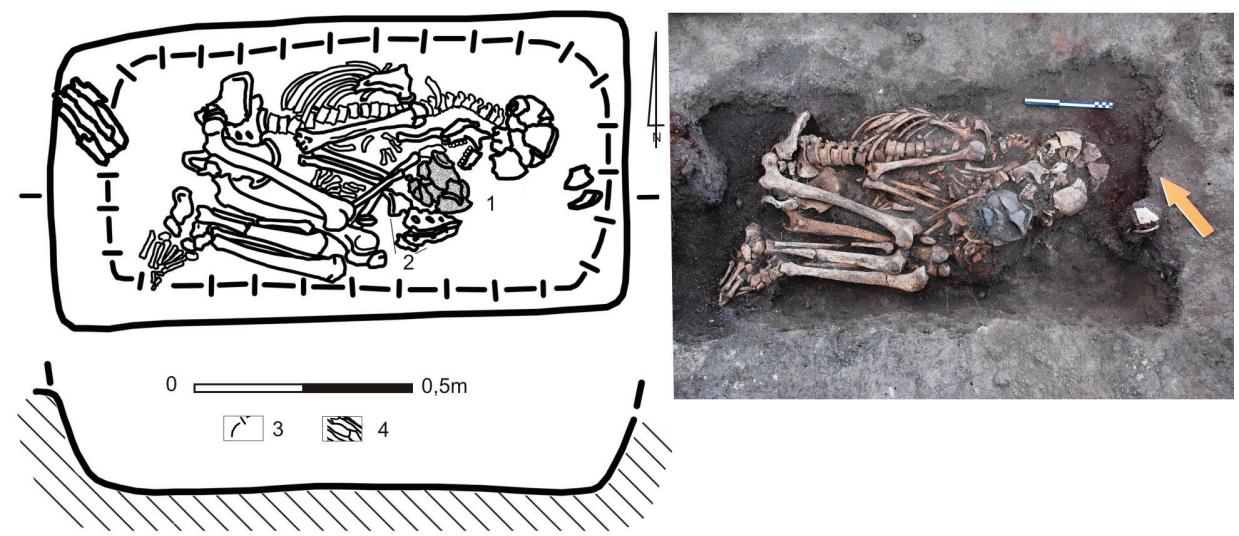

F i g . 1 5 . Porohy, Yampil Region, barrow 3A. Plan and profile of feature 3A/5. 1 - ceramic vessel; 2 - horse sacral bone; 3 - outline of mat; 4 - wood remains

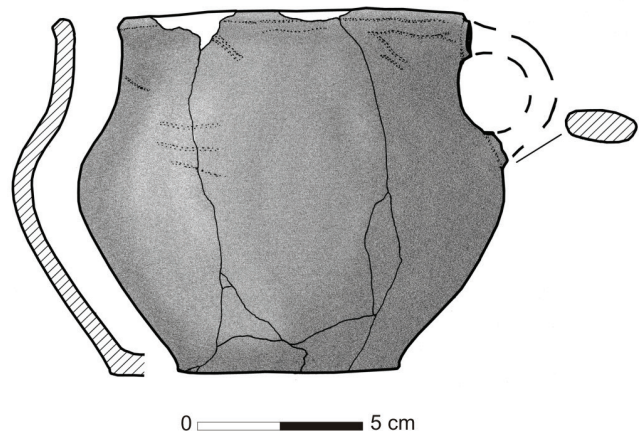

Fig. 16 . Porohy, Yampil Region, barrow 3A. Vessel from feature 3A/5 (see Fig. 15) 
Feature 3A/6

\begin{tabular}{|l|l|}
\hline Culture & Eneolithic? \\
\hline Dating & \\
\hline Structure type & Posthole \\
\hline Size at the level of discovery & $?$ \\
\hline Size at the level of the bottom & $0.7 \times 0.7 \mathrm{~m}$ \\
\hline Depth & $2.05 \mathrm{~m}$ \\
\hline Pit orientation & NW-SE \\
\hline Deviation & $?$ \\
\hline Distance from barrow centre & $6 \mathrm{~m}$ \\
\hline Azimuth & $351^{\circ}$ \\
\hline Comments & \\
\hline
\end{tabular}

A posthole discovered in the northern portion of the barrow. Its fill consisted of chernozem with fine charcoals. From depths from 0.8 to $1.5 \mathrm{~m}$, eight lime stones, from 0.2 to $0.5 \mathrm{~m}$ in diameter were recovered. Judging by the barrow profile, it can be assumed that the posthole was sunk into the oldest mound of the barrow at a depth of $1.2 \mathrm{~m}$ (Fig. 17:A).

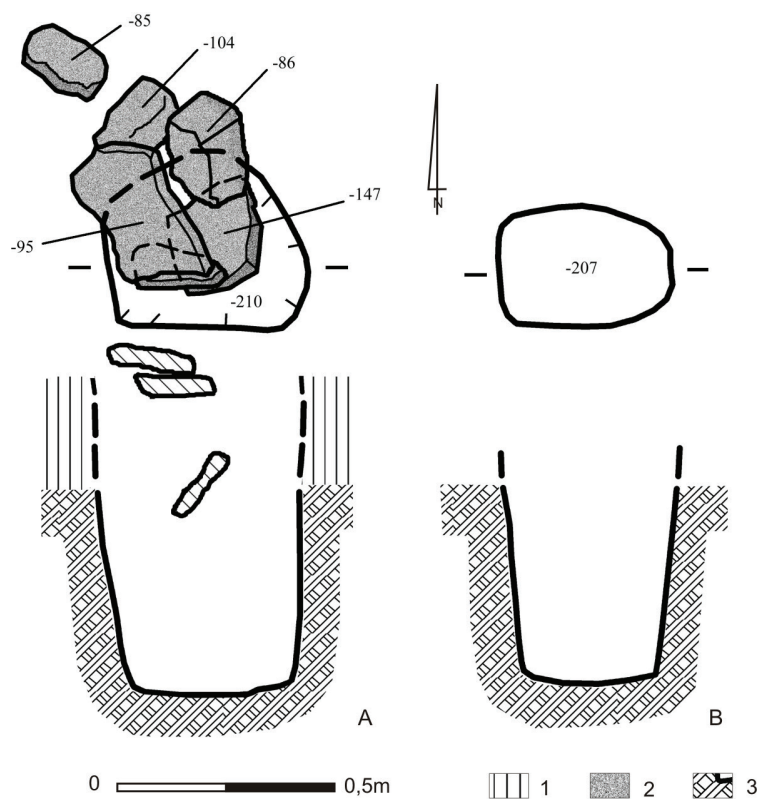

Fig. 1 7. Porohy, Yampil Region, barrow 3A. A - plan and profile of feature 3A/6; B - plan and profile of feature $3 \mathrm{~A} / 13.1$ - layer under the barrow mound; 2 - stones; 3 - sterile soil 
Feature 3A/7

\begin{tabular}{|c|c|c|c|}
\hline Culture & \multicolumn{3}{|l|}{ Noua } \\
\hline Dating & \multicolumn{3}{|c|}{ Poz-70667: 4115 \pm 35 BP (human bone) } \\
\hline \multicolumn{2}{|l|}{ Grave pit } & \multicolumn{2}{|l|}{ Burial } \\
\hline Structure type & Pit & Sex & Male? \\
\hline Number of burials & 1 & Age & Adultus-Maturus \\
\hline $\begin{array}{l}\text { Size at the level } \\
\text { of discovery }\end{array}$ & $?$ & Orientation & E-W \\
\hline $\begin{array}{l}\text { Size at the level } \\
\text { of the bottom }\end{array}$ & Approx. $1.3 \times 1.0 \mathrm{~m}$ & Deviation & $0^{\circ}$ \\
\hline Depth & $0.65 \mathrm{~m}$ & Arrangement of head & $\mathrm{P}$ \\
\hline Pit orientation & $\mathrm{N}-\mathrm{S}$ & Arrangement of trunk & $\mathrm{P}$ \\
\hline Deviation & $0^{\circ}$ & Upper limbs & $\mathrm{D}$ \\
\hline $\begin{array}{l}\text { Distance from barrow } \\
\text { centre }\end{array}$ & $4.85 \mathrm{~m}$ & Lower limbs & 1 \\
\hline Azimuth & $107^{\circ}$ & Ochre & + \\
\hline Wooden roofing & + & Presence of mat & + \\
\hline $\begin{array}{l}\text { Roofing element } \\
\text { orientation }\end{array}$ & Perpendicular & Animal bones & - \\
\hline $\begin{array}{l}\text { Other structural } \\
\text { elements }\end{array}$ & - & Ritual objects & $\begin{array}{l}\text { Vessel fragment, ochre } \\
\text { lump next to the face, } \\
\text { unidentified mineral } \\
\text { substance }\end{array}$ \\
\hline
\end{tabular}

The grave was sunk into the eastern portion of the mound. The pit outline could not be captured. Judging by the shape of the mat, it can be assumed to have been rectangular. In the SW corner, the fragment of a wooden roofing was discovered, measuring $10.0 \times 3.0 \mathrm{~cm}$. On the bottom, there lay a skeleton of an adult male crouched on the right side. Its bones were slightly coloured with ochre. In the SE corner of the pit, the lower portion of a flat-bottom vessel was found. It bore traces of fire (a container for keeping embers?). Between the vessel and skull, there lay an oval ochre lump of a bright red colour and north of it, a strongly overheated mineral substance of a red colour was found (Fig. 18).

Grave goods

1. The lower portion of a flat-bottom vessel with even, mat outer surfaces of a light-brown colour. The clay contains temper of crushed ceramics. Dimensions: bottom diameter $-8.5 \mathrm{~cm}$, maximum diameter $-11 \mathrm{~cm}$, wall thickness $-0.8 \mathrm{~cm}$ (Figs. 18: 3; 19).

2. Ochre lump measuring $8 \times 5 \times 2 \mathrm{~cm}$ (Fig. 18:1).

3. Lump of overheated mineral substance measuring $7 \times 3 \times 2 \mathrm{~cm}$ (Fig. 18: 2). 

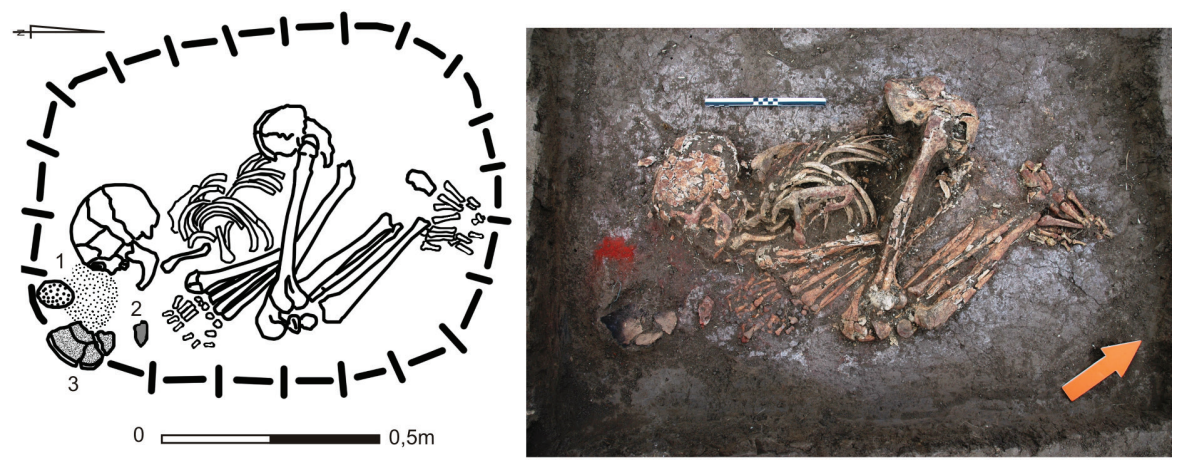

$r^{\circ} 4$

Fig. 18 . Porohy, Yampil Region, barrow 3A. Plan of feature 3A/7: 1 - lump of ochre; 2 - mineral of a red colour; 3 - fragments of a vessel bottom (see Fig. 19); 4 - outline of mat; 5 - ochre

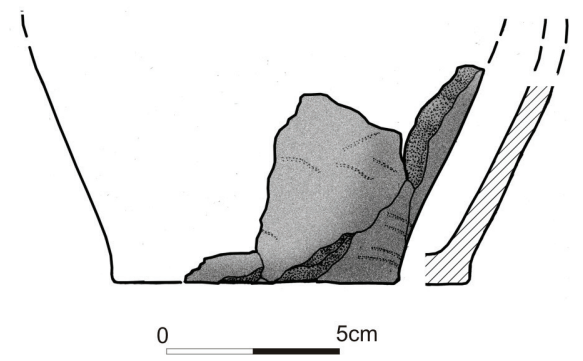

Fi g. 19. Porohy, Yampil Region, barrow 3A. Ceramic vessel from feature 3A/7 (see Fig. 18)

Feature $3 A / 8$

\begin{tabular}{|c|c|c|c|}
\hline Culture & \multicolumn{3}{|l|}{ Noua } \\
\hline \multicolumn{4}{|l|}{ Dating } \\
\hline \multicolumn{2}{|l|}{ Grave pit } & \multicolumn{2}{|l|}{ Burial } \\
\hline Structure type & Pit & Sex & Male \\
\hline Number of burials & 1 & Age & $25-30$ years \\
\hline $\begin{array}{l}\text { Size at the level } \\
\text { of discovery }\end{array}$ & $?$ & Orientation & SE-NW \\
\hline $\begin{array}{l}\text { Size at the level } \\
\text { of the bottom }\end{array}$ & Approx. $1.4 \times 0.7 \mathrm{~m}$ & Deviation & $20^{\circ} \mathrm{N}$ \\
\hline Depth & $0.6 \mathrm{~m}$ & Arrangement of head & $\mathrm{L}$ \\
\hline Pit orientation & W-E & Arrangement of trunk & $\mathrm{L}$ \\
\hline Deviation & $19^{\circ}$ & Upper limbs & $?$ \\
\hline
\end{tabular}




\begin{tabular}{|l|l|l|l|}
\hline $\begin{array}{l}\text { Distance from barrow } \\
\text { centre }\end{array}$ & $11.6 \mathrm{~m}$ & Lower limbs & $?$ \\
\hline Azimuth & $178^{\circ}$ & Ochre & - \\
\hline Wooden roofing & - & Presence of mat & + \\
\hline $\begin{array}{l}\text { Roofing element } \\
\text { orientation }\end{array}$ & Animal bones & - \\
\hline $\begin{array}{l}\text { Other structural } \\
\text { elements }\end{array}$ & - & Ritual objects & - \\
\hline Comments & \multicolumn{3}{|l}{} \\
\hline
\end{tabular}

The grave was sunk into the southern edge of the mound and was partially damaged. In situ, there lay only a skull, clavicle and the fragment of a scapula. The skeleton of an adult male rested crouched on its left side. Judging by the shape of the mat lying on the feature bottom, it can be assumed that the pit was rectangular (Fig. 20).

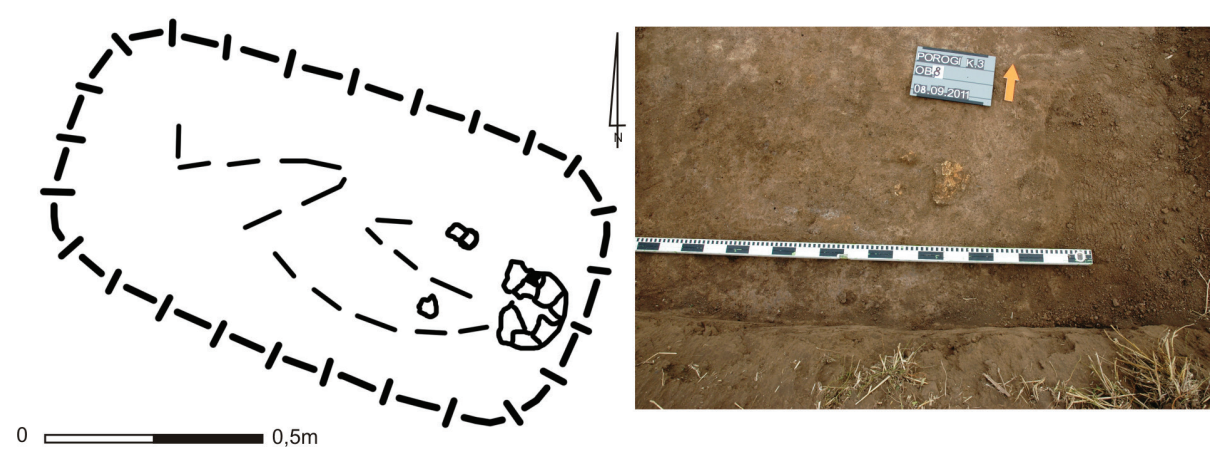

Fig . 2 0. Porohy, Yampil Region, barrow 3A. Plan of feature 3A/8 
Feature 3A/10

\begin{tabular}{|c|c|c|c|}
\hline Culture & \multicolumn{3}{|l|}{ Yamnaya } \\
\hline Dating & \multicolumn{3}{|c|}{$\begin{array}{l}\text { Ki-17383: } 3860 \pm 160 \mathrm{BP} ; \mathrm{Ki}-17438: 4370 \pm 70 \mathrm{BP} \\
\text { Ki-18928: } 4070 \pm 50 \mathrm{BP} \text {; Poz-74393: } 4105 \pm 35 \mathrm{BP} \\
\text { Poz-81824: } 4040 \pm 35 \mathrm{BP} \text { (human bones) }\end{array}$} \\
\hline \multicolumn{2}{|l|}{ Grave pit } & \multicolumn{2}{|l|}{ Burial } \\
\hline Structure type & Pit & Sex & Female \\
\hline Number of burials & 1 & Age & $25-30$ years \\
\hline $\begin{array}{l}\text { Size at the level } \\
\text { of discovery }\end{array}$ & $2.35 \times 1.9 \mathrm{~m}$ & Orientation & NW-SE \\
\hline $\begin{array}{l}\text { Size at the level } \\
\text { of the bottom }\end{array}$ & $1.7 \times 1.4 \mathrm{~m}$ & Deviation & $8^{\circ} \mathrm{E}$ \\
\hline Depth & $1.3 \mathrm{~m}$ & Arrangement of head & $\mathrm{P}$ \\
\hline Pit orientation & NW-SE & Arrangement of trunk & $\mathrm{P}$ \\
\hline Deviation & $4^{\circ} \mathrm{E}$ & Upper limbs & A \\
\hline $\begin{array}{l}\text { Distance from barrow } \\
\text { centre }\end{array}$ & $4.97 \mathrm{~m}$ & Lower limbs & 2 \\
\hline Azimuth & $67^{\circ}$ & Ochre & + \\
\hline Wooden roofing & + & Presence of mat & + \\
\hline $\begin{array}{l}\text { Roofing element } \\
\text { orientation }\end{array}$ & Perpendicular & Animal bones & $\begin{array}{l}10 \text { fragments of sheep/ } \\
\text { goat bones }\end{array}$ \\
\hline $\begin{array}{l}\text { Other structural } \\
\text { elements }\end{array}$ & - & Ritual objects & $\begin{array}{l}\text { Lump of ochre, bone } \\
\text { awl (?) }\end{array}$ \\
\hline Comments & \multicolumn{3}{|c|}{$\begin{array}{l}\text { A circular hearth on the step in the SE of the feature. The bones of the } \\
\text { left forearm bear traces of a tattoo. }\end{array}$} \\
\hline
\end{tabular}

The grave was sunk into the eastern part of the mound. The rectangular outline of the pit was captured at a depth of $0.45 \mathrm{~m}$. A step leading to the grave chamber was located at a depth of $0.75 \mathrm{~m}$. In its SE part, the traces of a circular hearth, $0.3 \mathrm{~m}$ in diameter, were recorded together with a fill sunk about $0.1 \mathrm{~m}$, which resembled a trough. It consisted of burned earth, ash and charcoals. The step also bore traces of the wooden elements of a perpendicular roofing up to $0.2 \mathrm{~m}$ wide and $0.05 \mathrm{~m}$ thick.

The grave chamber was regularly rectangular and $0.6 \mathrm{~m}$ deep. On its bottom, there lay the skeleton of a female adultus crouched on the right side. The bones bore traces of colouring with ochre. Underneath her left elbow and next to the skull, the phalanges and hoofs of a sheep/goat were found. Twenty centimetres $\mathrm{W}$ of the right lower limb, a lump of ochre lay. From underneath the chest bones, a bone awl was recovered. On the bones of both forearms, the traces of a tattoo were visible. It consisted of wavy and cross patterns made with a dark blue pigment (Figs. 21-23).

Grave goods

1. Oval lump of red ochre measuring $8 \times 5 \mathrm{~cm}$ (Fig. 21: 1; 22).

2. Awl with a damaged point made from a fragment of the tubular bone of a sheep/goat. Dimensions: $7 \times 1.5 \times 0.5 \mathrm{~cm}$ (Figs. 21 : 3; 22; 23: 3). 


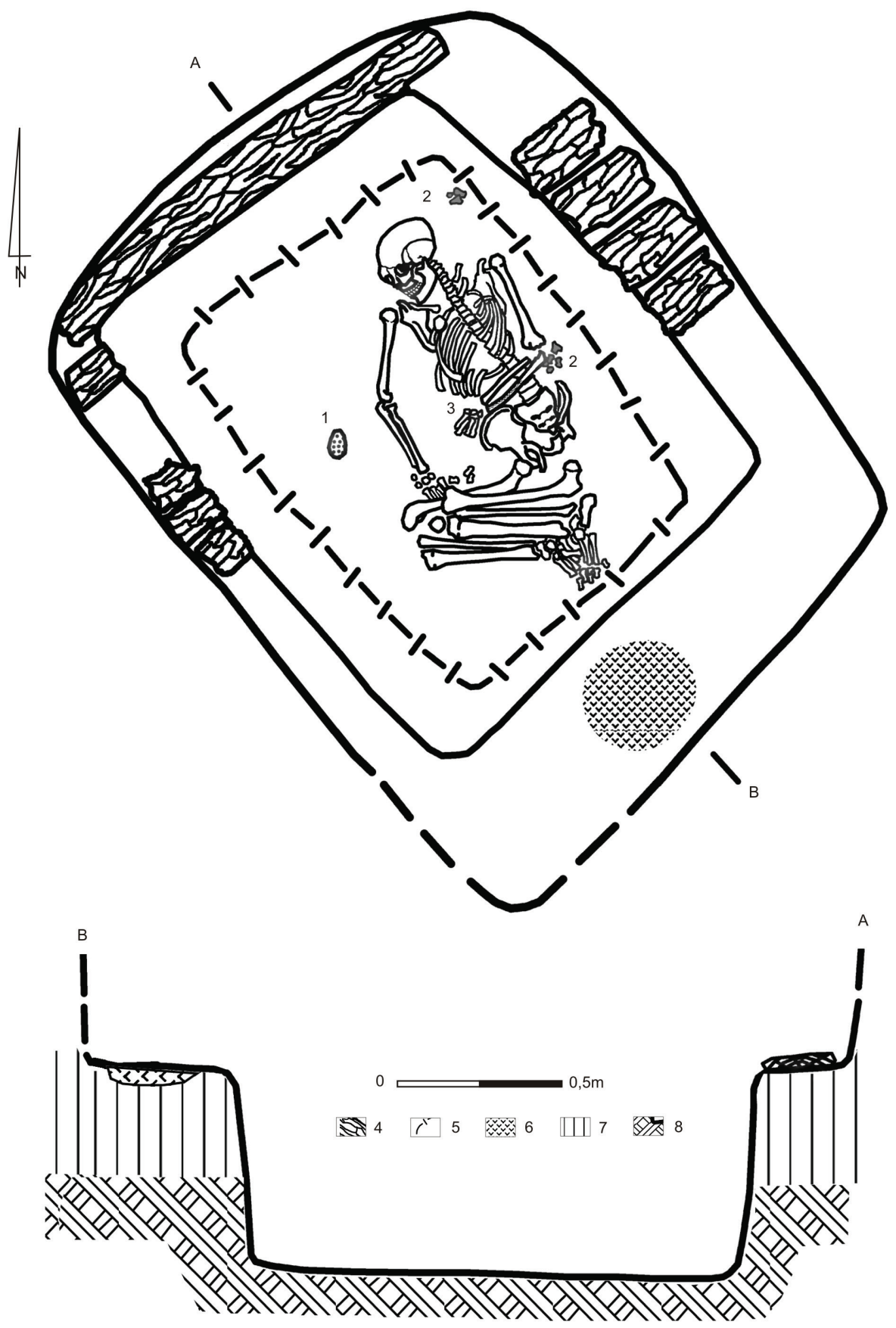

Fig. 21. Porohy, Yampil Region, barrow 3A. Plan and profile of feature 3A/10: 1 - lump of ochre; 2 - phalanges and hoofs of small horned cattle; 3 - cattle bone tool; 4 - wood remains; 5 outline of mat; 6 - hearth; 7 - layer under the barrow mound; 8 - sterile soil 


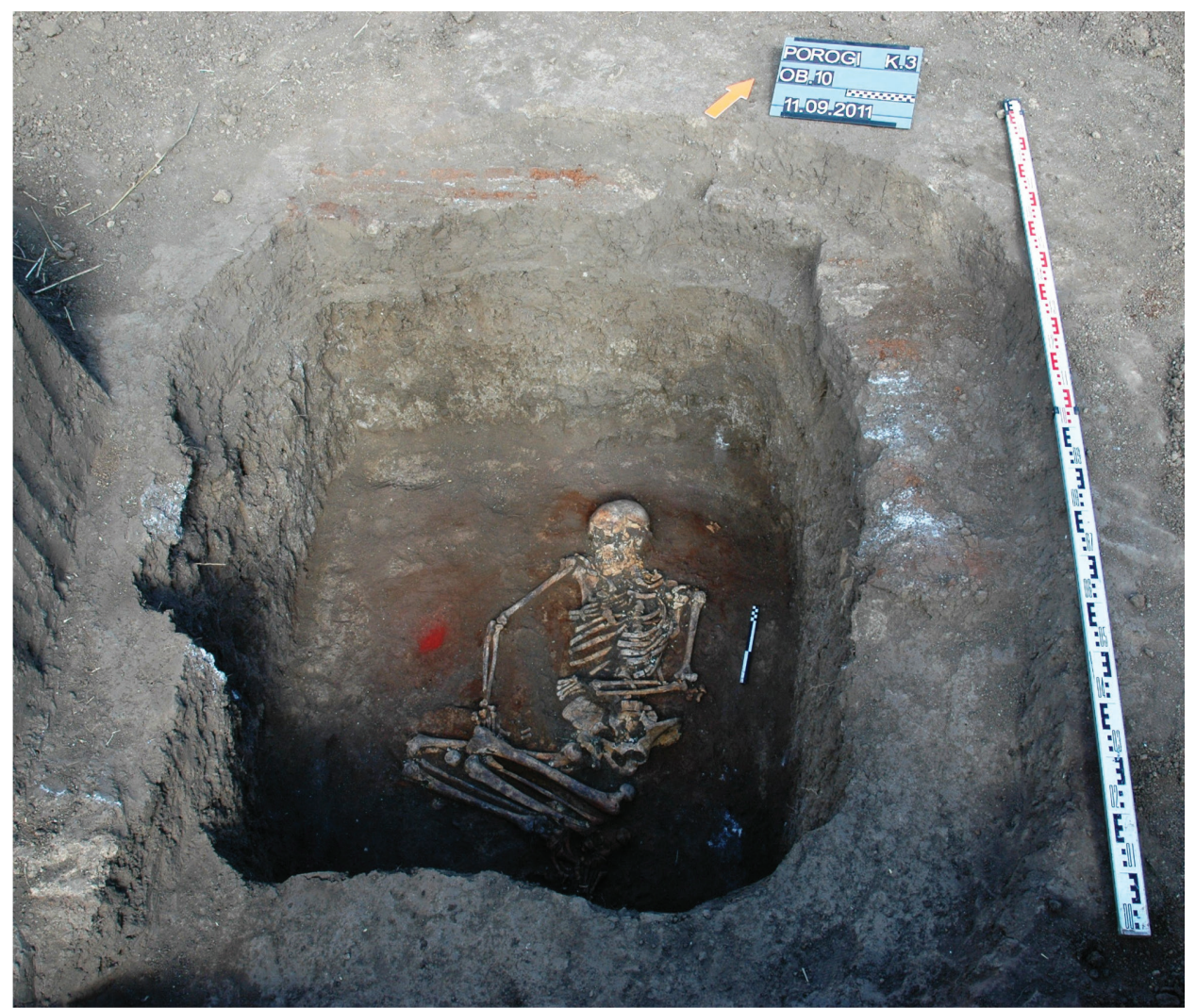

Fig. 22. Porohy, Yampil Region, barrow 3A. Plan of feature 3A/10 


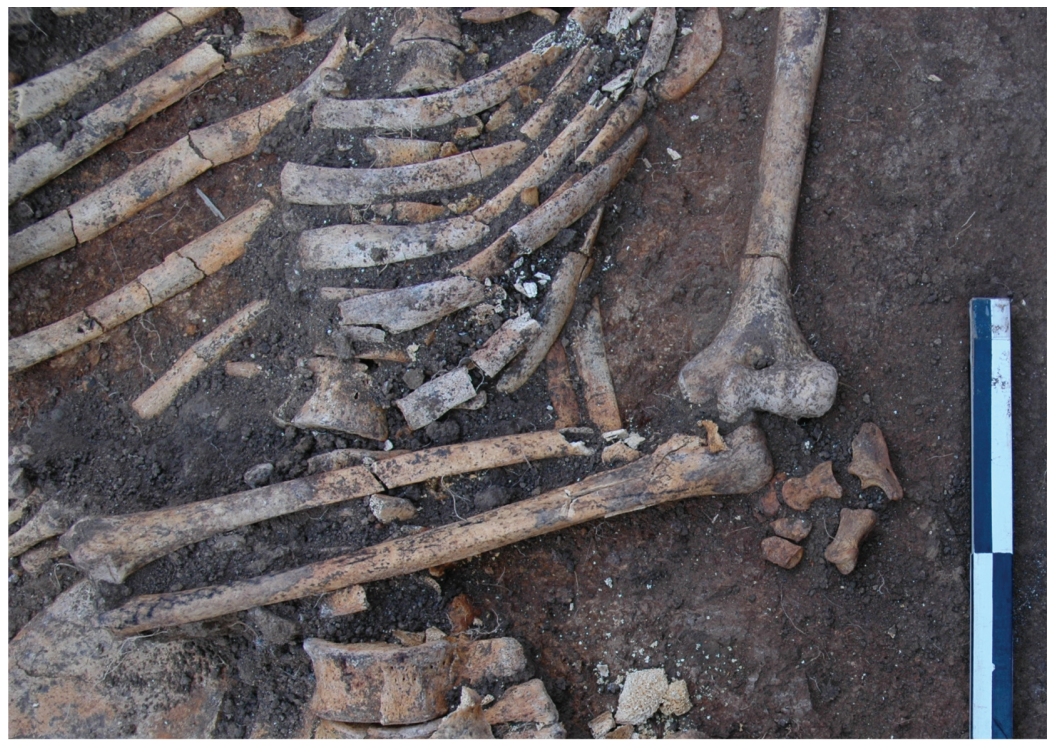

1
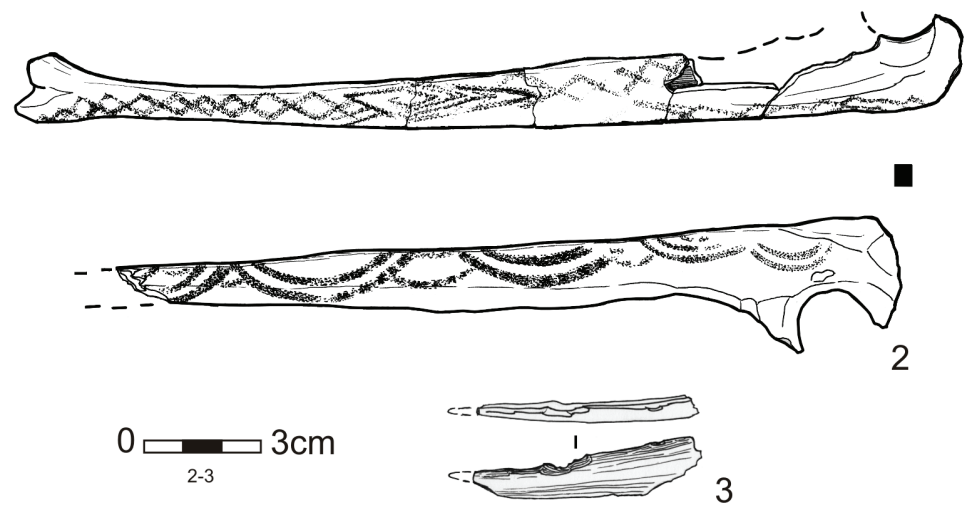

Fig. 23. Porohy, Yampil Region, barrow 3A. Feature 3A/10 - bones with a colorant: 1 - location in situ; 2 - drawing of a 'tattoo'; 3 - bone tool from the feature 
Feature 3A/11

\begin{tabular}{|c|c|c|c|}
\hline Culture & \multicolumn{3}{|l|}{ Yamnaya } \\
\hline Dating & \multicolumn{3}{|c|}{ Poz-47741: $4075 \pm 35$ BP (human bone) } \\
\hline \multicolumn{2}{|l|}{ Grave pit } & \multicolumn{2}{|l|}{ Burial } \\
\hline Structure type & Pit & Sex & Male \\
\hline Number of burials & 1 & Age & $25-30$ years \\
\hline $\begin{array}{l}\text { Size at the level } \\
\text { of discovery }\end{array}$ & $2.05 \times 1.55 \mathrm{~m}$ & Orientation & $\mathrm{N}-\mathrm{S}$ \\
\hline $\begin{array}{l}\text { Size at the level } \\
\text { of the bottom }\end{array}$ & $1.5 \times 1.05 \mathrm{~m}$ & Deviation & $0^{\circ}$ \\
\hline Depth & $1.45 \mathrm{~m}$ & Arrangement of head & $\mathrm{L}$ \\
\hline Pit orientation & $\mathrm{N}-\mathrm{S}$ & Arrangement of trunk & Supine \\
\hline Deviation & $0^{\circ}$ & Upper limbs & I \\
\hline $\begin{array}{l}\text { Distance from barrow } \\
\text { centre }\end{array}$ & $6.01 \mathrm{~m}$ & Lower limbs & 9 \\
\hline Azimuth & $107^{\circ}$ & Ochre & + \\
\hline Wooden roofing & + & Presence of mat & + \\
\hline $\begin{array}{l}\text { Roofing element } \\
\text { orientation }\end{array}$ & Longitudinal & Animal bones & $\begin{array}{l}\text { Skull of a goat (without } \\
\text { the mandible) }\end{array}$ \\
\hline $\begin{array}{l}\text { Other structural } \\
\text { elements }\end{array}$ & $\begin{array}{l}\text { Four posts in pit } \\
\text { corners }\end{array}$ & Ritual objects & $\begin{array}{l}\text { Retouched flake, lump } \\
\text { of ochre }\end{array}$ \\
\hline Comments & \multicolumn{3}{|c|}{ Within the pelvis, two point fragments were discovered. } \\
\hline
\end{tabular}

The grave was sunk into the eastern part of the mound. The structure consisted of an entrance pit with a step (at a depth of $1.55 \mathrm{~m}$ ), leading to a grave chamber. The roofing consisted of eight longitudinally placed planks of up to $0.2 \mathrm{~m}$ wide, additionally covered with a mat. On the step, in the SE corner (at a depth of $0.8 \mathrm{~m}$ ), there lay the skull of a domesticated goat, with its muzzle pointing W. The grave chamber was regularly rectangular. In its corners, four holes were exposed left by wooden posts $(5 \mathrm{~cm}$ in diameter and $8 \mathrm{~cm}$ deep). On the pit bottom, there rested the skeleton of a male adultus, lying supine with his lower limbs spreading outwards - forming a rhomboid. Underneath the skull, a concentration of ochre was recorded. Within the pelvic girdle, two fragments of a flint point, and at the left arm, a retouched flint flake were found (Figs. 24; 25).

Grave goods

1. Two strongly calcified fragments of a flint arrowhead with a deep, triangular notch (Fig. 24: 1).

2. Retouched flint flake (Fig. 24: 2).

3. Lump of ochre. 


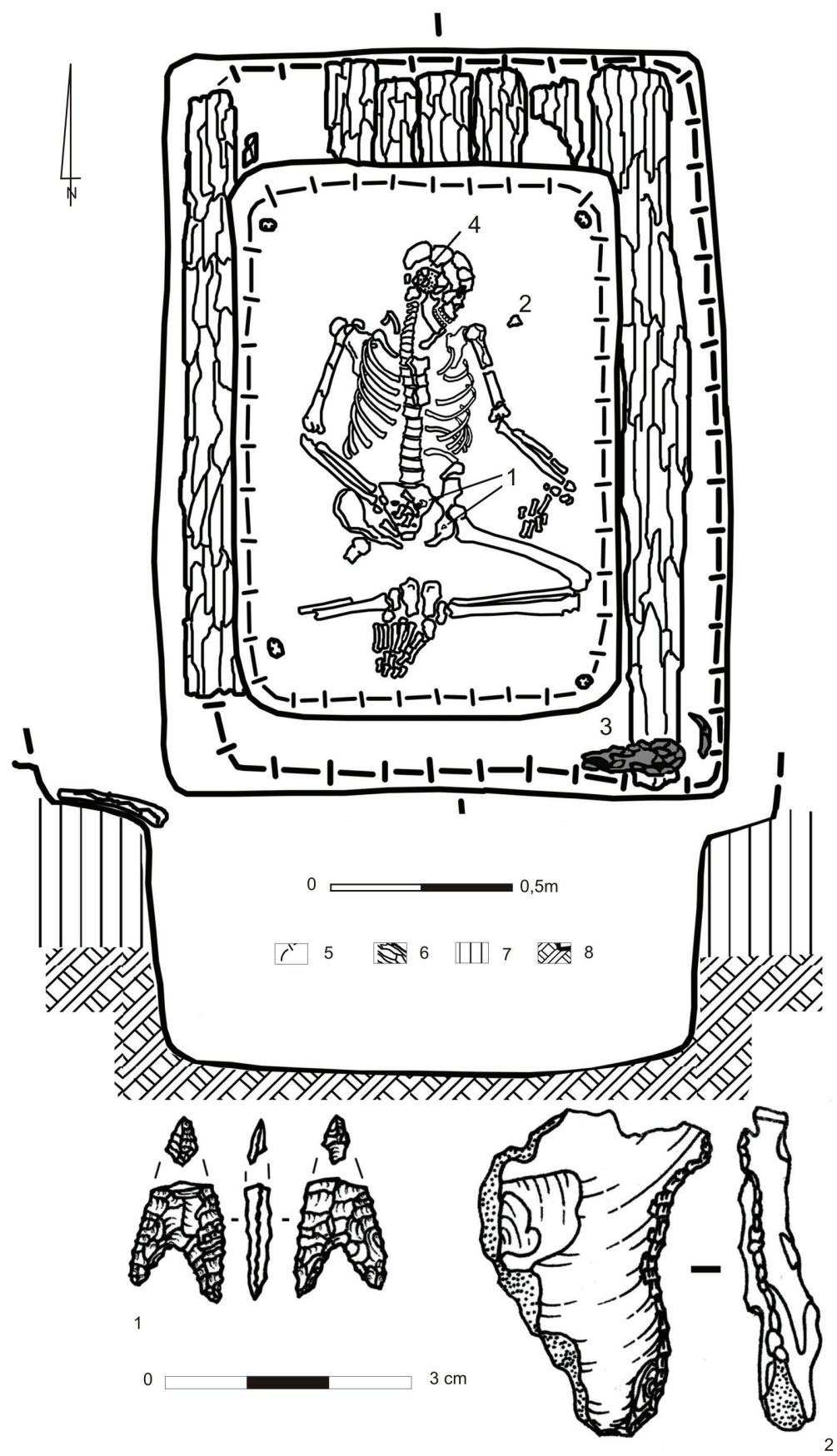

Fig. 24. Porohy, Yampil Region, barrow 3A. Plan and profile of feature 3A/11: 1 - fragments of a flint arrow point; 2 - flint flake; 3 - skull of male goat; 4 - ochre; 5 - outline of mat; 6 - wood remains; 7 - layer under the barrow mound; 8 - sterile soil 


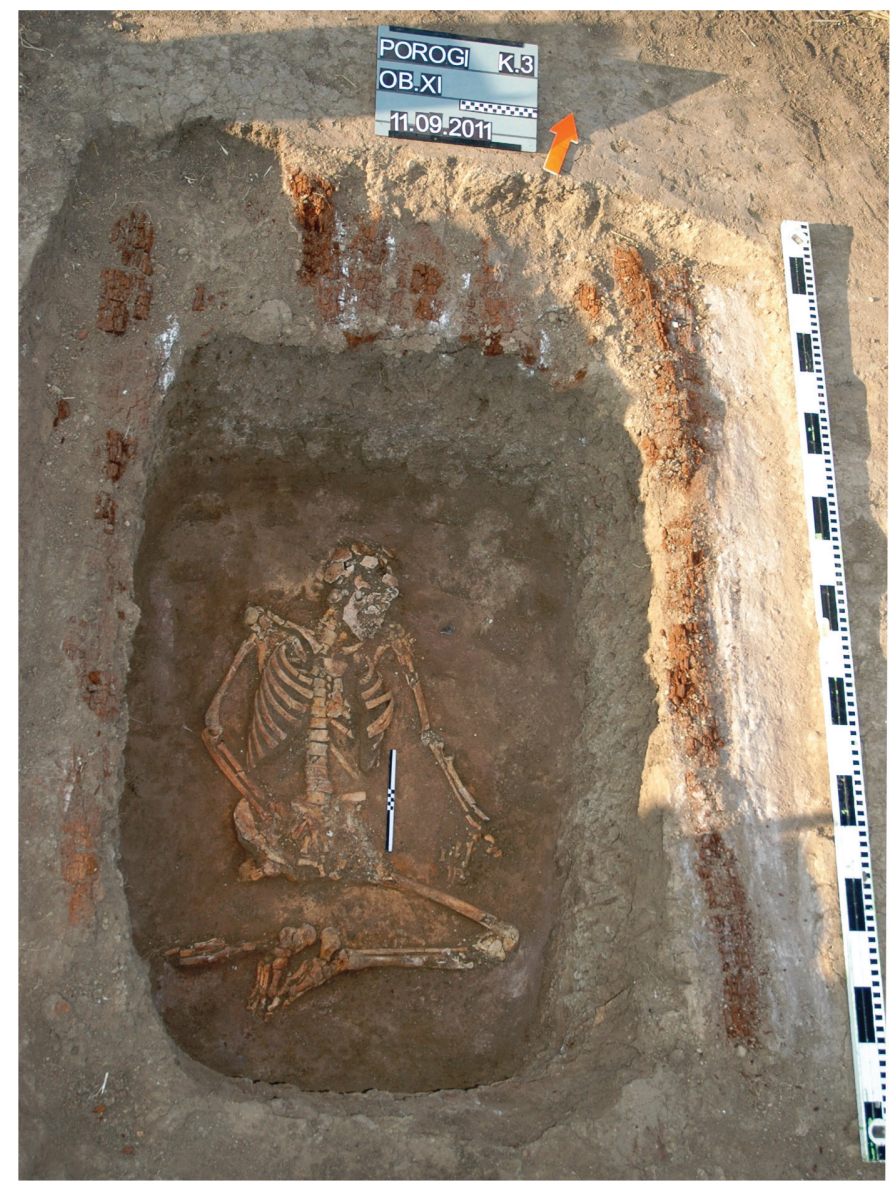

Fig. 25 . Porohy, Yampil Region, barrow 3A. Plan of feature 3A/11 
Feature 3A/12

\begin{tabular}{|c|c|c|c|}
\hline Culture & \multicolumn{3}{|l|}{ Yamnaya } \\
\hline Dating & \multicolumn{3}{|c|}{ Poz-47742: $3985 \pm 35$ BP (human bone) } \\
\hline \multicolumn{2}{|l|}{ Grave pit } & \multicolumn{2}{|l|}{ Burial } \\
\hline Structure type & Pit & Sex & Female \\
\hline Number of burials & 2 & Age & $22-25$ years \\
\hline $\begin{array}{l}\text { Size at the level } \\
\text { of discovery }\end{array}$ & $1.8 \times 1.3 \mathrm{~m}$ & Orientation & SE-NW \\
\hline $\begin{array}{l}\text { Size at the level } \\
\text { of the bottom }\end{array}$ & $1.3 \times 0.95 \mathrm{~m}$ & Deviation & $9^{\circ} \mathrm{E}$ \\
\hline Depth & $1.15 \mathrm{~m}$ & Arrangement of head & $\mathrm{L}$ \\
\hline Pit orientation & W-E & Arrangement of trunk & $\mathrm{L}$ \\
\hline Deviation & $19^{\circ} \mathrm{S}$ & Upper limbs & $\mathrm{I}$ \\
\hline $\begin{array}{l}\text { Distance from barrow } \\
\text { centre }\end{array}$ & $5.45 \mathrm{~m}$ & Lower limbs & 5 \\
\hline Azimuth & $16^{\circ}$ & Ochre & + \\
\hline Wooden roofing & + & Presence of mat & + \\
\hline $\begin{array}{l}\text { Roofing element } \\
\text { orientation }\end{array}$ & Perpendicular & Animal bones & - \\
\hline $\begin{array}{l}\begin{array}{l}\text { Other structural } \\
\text { elements }\end{array} \\
\end{array}$ & - & Ritual objects & $\begin{array}{l}\text { Flint flake, lump of } \\
\text { ochre }\end{array}$ \\
\hline Comments & \multicolumn{3}{|c|}{ Remains of an unborn child on the pelvic bones. } \\
\hline
\end{tabular}

The grave was sunk into the northern portion of the mound centre. The grave chamber was entered through a step at a depth of about $0.5 \mathrm{~m}$. It supported a roofing built from planks laid perpendicularly to the longer axis of the grave. The chamber was trapezial in shape. On its bottom, there lay the skeleton of a female adultus crouched on her left side. Within the abdomen and partially on the pelvic bones, there lay the remains of an unborn child. The woman died during perinatal age. About $12.0 \mathrm{~cm}$ E of the skull, a lump of ochre was discovered, measuring $4.0 \mathrm{~cm}$ in diameter. At the $\mathrm{S}$ pit wall, about $10.0 \mathrm{~cm}$ above the bottom, a flint flake was found (Figs. 26; 27).

Grave goods

1. Flint flake

2. Lump of ochre 


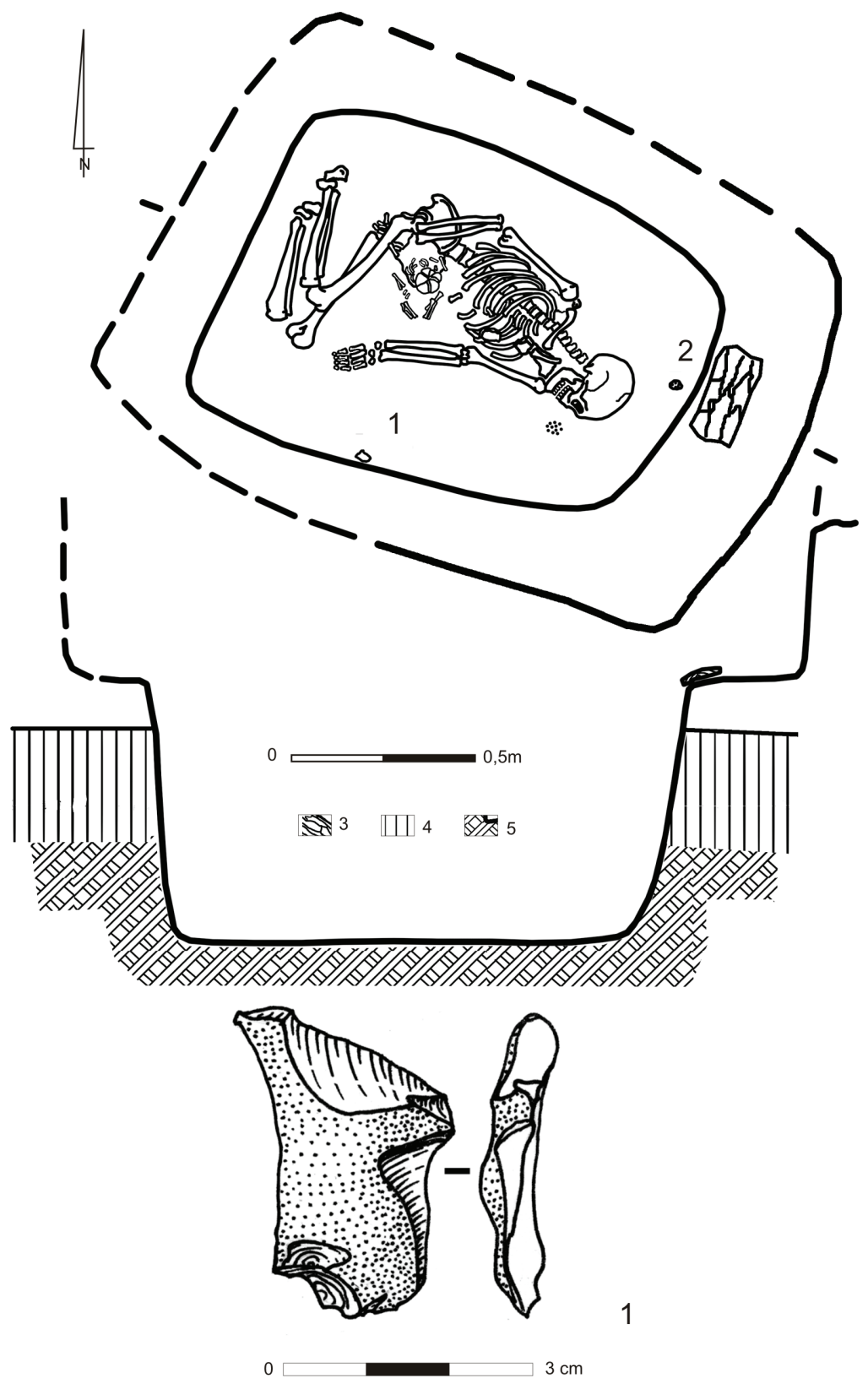

Fig. 26. Porohy, Yampil Region, barrow 3A. Plan and profile of feature 3A/12: 1 - flint flake; 2 - lump of ochre; 3 - wood remains; 4 - layer under the barrow mound; 5 - sterile soil 


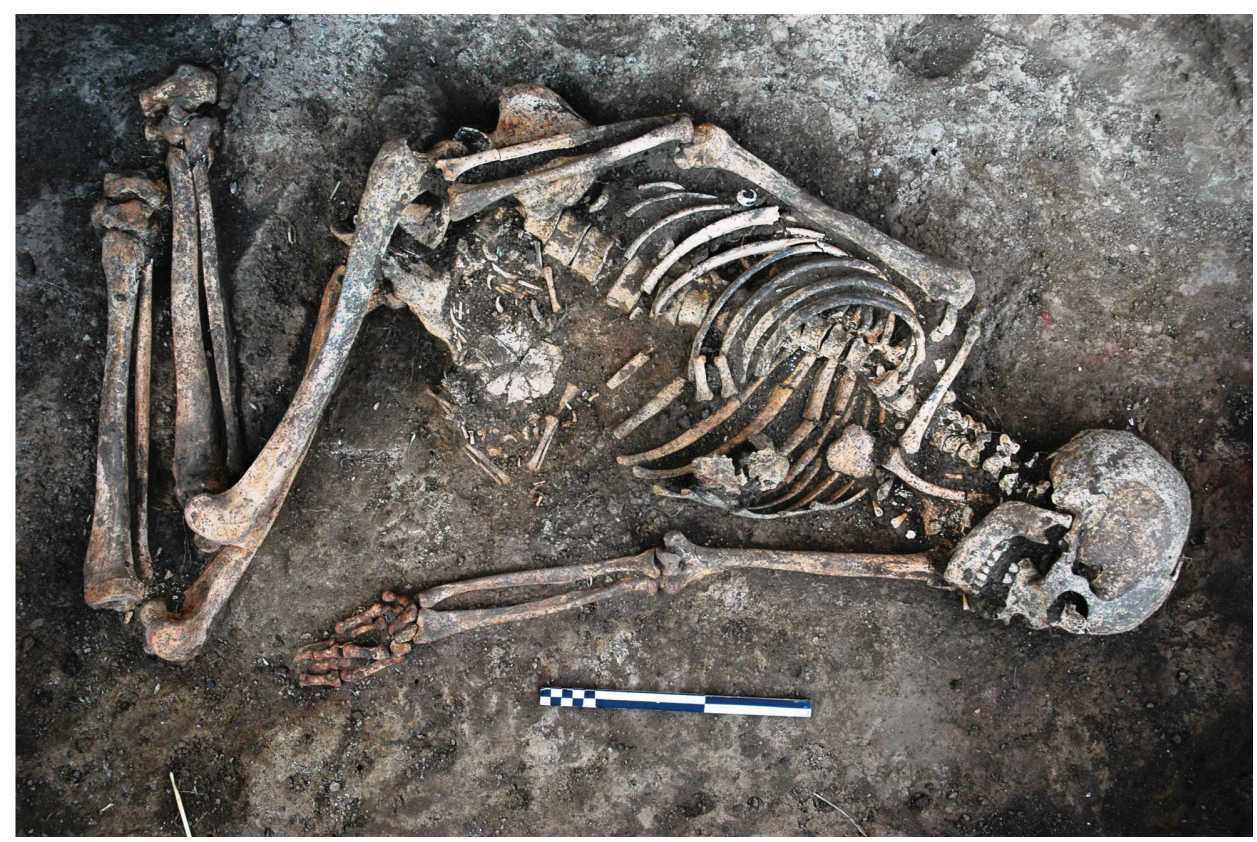

Fig. 27 . Porohy, Yampil Region, barrow 3A. Plan of feature 3A/12.

\section{Feature $3 A / 13$}

\begin{tabular}{|l|l|}
\hline Culture & Eneolthic? \\
\hline Dating & \\
\hline Structure type & Posthole \\
\hline Size at the level of discovery & $?$ \\
\hline Size at the level of the bottom & $0.6 \times 0.4 \mathrm{~m}$ \\
\hline Depth & $?$ \\
\hline Pit orientation & $?$ \\
\hline Deviation & $?$ \\
\hline Distance from barrow centre & $6.8 \mathrm{~m}$ \\
\hline Azimuth & $334^{\circ}$ \\
\hline Comments & \\
\hline
\end{tabular}

The posthole was discovered $1.2 \mathrm{~m}$ west of feature 6 . It was subrectangular and measured $0.3 \times 0.5 \mathrm{~m}$. It was $1.95 \mathrm{~m}$ deep (Fig. 17: B). 
Feature 3A/14

\begin{tabular}{|c|c|c|c|}
\hline Culture & \multicolumn{3}{|l|}{ Eneolithic? } \\
\hline Dating & \multicolumn{3}{|c|}{ Poz-74396: $3674 \pm 35$ BP (human bone) } \\
\hline \multicolumn{2}{|l|}{ Grave pit } & \multicolumn{2}{|l|}{ Burial } \\
\hline Structure type & Pit? & Sex & $\begin{array}{l}\text { 1. ? } \\
\text { 2. ? }\end{array}$ \\
\hline Number of burials & 2 & Age & $\begin{array}{l}\text { 1. Adult } \\
\text { 2. Child }\end{array}$ \\
\hline $\begin{array}{l}\text { Size at the level } \\
\text { of discovery }\end{array}$ & $2.65 \times 2.1 \mathrm{~m}$ & Orientation & \\
\hline $\begin{array}{l}\text { Size at the level } \\
\text { of the bottom }\end{array}$ & $2.5 \times 2.2 \mathrm{~m}$ & Deviation & \\
\hline Depth & $2.2 \mathrm{~m}$ & Arrangement of head & $\begin{array}{l}\text { 1. ? } \\
\text { 2.? }\end{array}$ \\
\hline Pit orientation & NW-SE? & Arrangement of trunk & $\begin{array}{l}\text { 1. ? } \\
\text { 2.? }\end{array}$ \\
\hline Deviation & $?$ & Upper limbs & $\begin{array}{l}\text { 1.? } \\
\text { 2.? }\end{array}$ \\
\hline $\begin{array}{l}\text { Distance from barrow } \\
\text { centre }\end{array}$ & & Lower limbs & $\begin{array}{l}\text { 1.? } \\
\text { 2.? }\end{array}$ \\
\hline Azimuth & & Ochre & - \\
\hline Wooden roofing & + & Presence of mat & - \\
\hline $\begin{array}{l}\text { Roofing element } \\
\text { orientation }\end{array}$ & $?$ & Animal bones & $\begin{array}{l}1 \text { frag. of deer antler } \\
\text { with traces of working, } \\
\text { from the fill } 5 \text { frag. of } \\
\text { deer antler with traces of } \\
\text { working, } 1 \text { frag. of deer } \\
\text { skull, } 2 \text { frag. of sheep/goat } \\
\text { bones, } 6 \text { frag. of bones of } \\
\text { unidentified species. }\end{array}$ \\
\hline $\begin{array}{l}\text { Other structural } \\
\text { elements }\end{array}$ & $\begin{array}{l}\text { Lime stones (ele- } \\
\text { ments of roofing?) }\end{array}$ & Ritual objects & - \\
\hline Comments & \multicolumn{3}{|c|}{ The feature was destroyed by a robber trench } \\
\hline
\end{tabular}

The central feature under the oldest mound was destroyed by a robber trench. The fill was found to contain the fragments of a wooden cover and lime stones (a block measuring $0.50 \times 0.30 \times 0.15 \mathrm{~m}$ was recovered from a depth of $2.0 \mathrm{~m}$ ). The outline of the pit was irregular and resembled a heart. The S part featured a step (at the level of $1.6 \mathrm{~m}$ ). At various depths, the bones of an adult individual and skull fragments of a child were found. Other finds included sheep/goat limb bones, two flint flakes, two pottery shards, a stone calcareous lump bearing traces of use (hammerstone?) and a fragment of a deer antler tool (Figs. 10-12).

\section{Grave goods}

1. Flint flake (Figs. 11: 4, 7). 
2. Fragments of the lip of a large hand-made vessel, ornamented with a corrugated relief strip under the rim. The clay contains temper of crushed ceramics (Fig. 11: 6).

3. Globular hammerstone made of lime stone (Fig. 11: 3).

4. Fragments of a deer antler tool (mattock?) (Fig. 11: 5).

Feature $3 A / 15$

\begin{tabular}{|c|c|c|c|}
\hline Culture & \multicolumn{3}{|l|}{ Yamnaya } \\
\hline Dating & \multicolumn{3}{|c|}{ Ki-17439: $3580 \pm 901 \mathrm{BP} ; \mathrm{Ki}-17386: 4010 \pm 220 \mathrm{BP}$ (human bones) } \\
\hline \multicolumn{2}{|l|}{ Grave pit } & \multicolumn{2}{|c|}{ Burial } \\
\hline Structure type & Pit & Sex & Male \\
\hline Number of burials & 1 & Age & 25-30 years \\
\hline $\begin{array}{l}\text { Size at the level } \\
\text { of discovery }\end{array}$ & $2.05 \times 1.85 \mathrm{~m}$ & Orientation & E-W \\
\hline $\begin{array}{l}\text { Size at the level } \\
\text { of the bottom }\end{array}$ & $1.7 \times 1.05 \mathrm{~m}$ & Deviation & $12^{\circ} \mathrm{N}$ \\
\hline Depth & $1.35 \mathrm{~m}$ & Arrangement of head & $\mathrm{L}$ \\
\hline Pit orientation & W-E & Arrangement of trunk & $\mathrm{L}$ \\
\hline Deviation & $11^{\circ} \mathrm{P}$ & Upper limbs & I \\
\hline $\begin{array}{l}\text { Distance from barrow } \\
\text { centre }\end{array}$ & $6.05 \mathrm{~m}$ & Lower limbs & $5 / 6$ \\
\hline Azimuth & $167^{\circ}$ & Ochre & + \\
\hline Wooden roofing & + & Presence of mat & + \\
\hline $\begin{array}{l}\text { Roofing element } \\
\text { orientation }\end{array}$ & Perpendicular & Animal bones & - \\
\hline $\begin{array}{l}\text { Other structural } \\
\text { elements }\end{array}$ & - & Ritual objects & $\begin{array}{l}1 \text { flint tool at the level of } \\
\text { grave cover }\end{array}$ \\
\hline Comments & & & \\
\hline
\end{tabular}

The grave was sunk into the southern portion of the mound. Rectangular in shape, at a depth of $0.7 \mathrm{~m}$, it featured a wide step, leading a regularly rectangular grave chamber. The step supported a perpendicular wooden roofing made from planks about $0.2 \mathrm{~m}$ wide and covered with a mat. On its NW part, a flint-flake knife lay. On the chamber bottom, the skeleton of a male adultus rested crouched on the left side. Under the pelvis, a layer of a yellow organic substance was recorded and measured to be $1.0 \mathrm{~cm}$ thick (Figs. 28-30).

\section{Grave goods}

1. Flint knife made from a massive, regular blade of semi-transparent Cretaceous flint dark-grey in colour. Regularly retouched on the distal part of both sides. Dimensions: $14 \times 3 \times 0.7 \mathrm{~cm}$ (Fig. 29). 


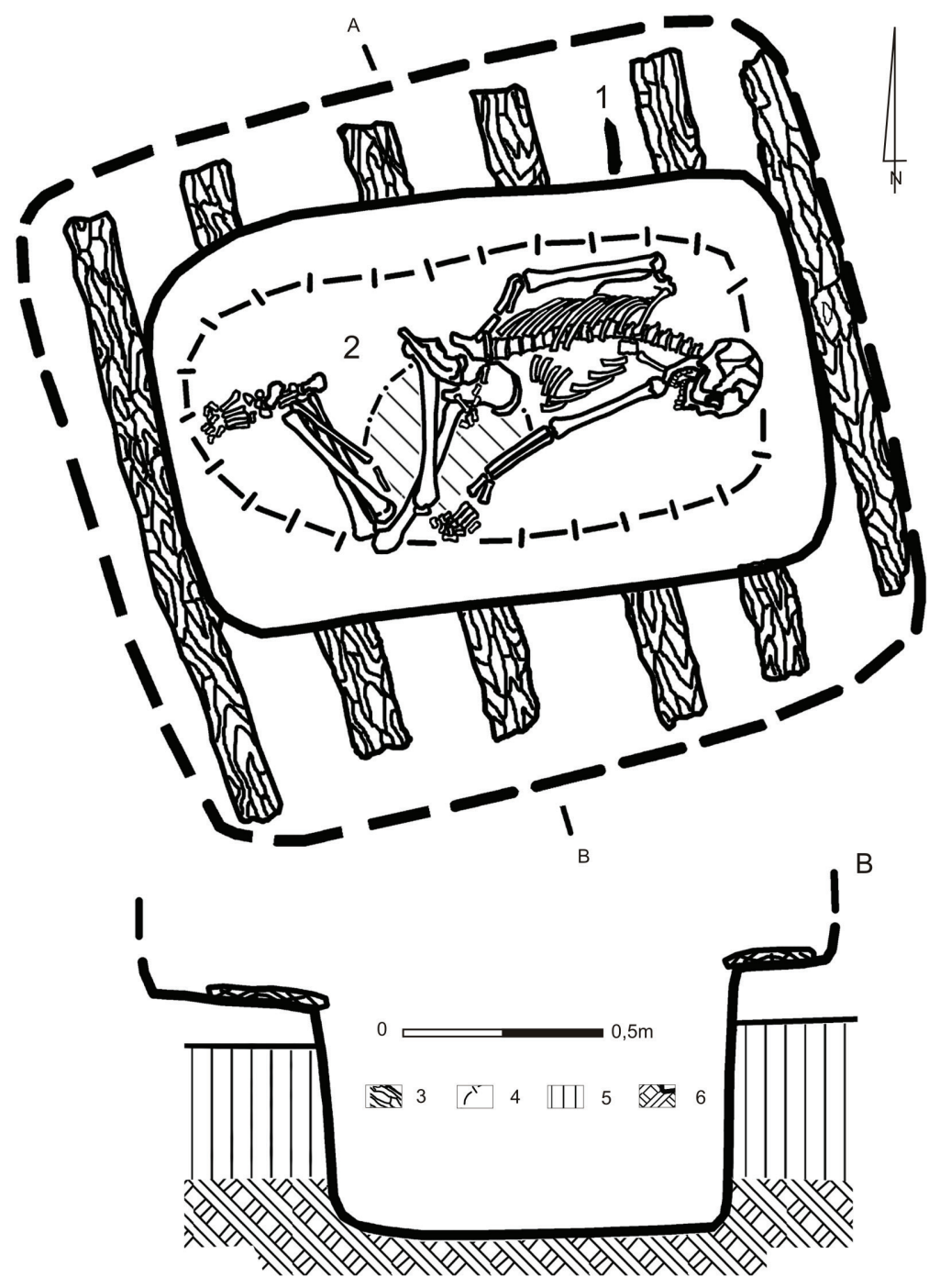

Fig. 2 8. Porohy, Yampil Region, barrow 3A. Plan and profile of feature 3A/15: 1 - flint blade; 2 - remains of organic matter; 3 - wood remains; 4 - outline of mat; 5 - layer under the barrow mound; 6 - sterile soil 


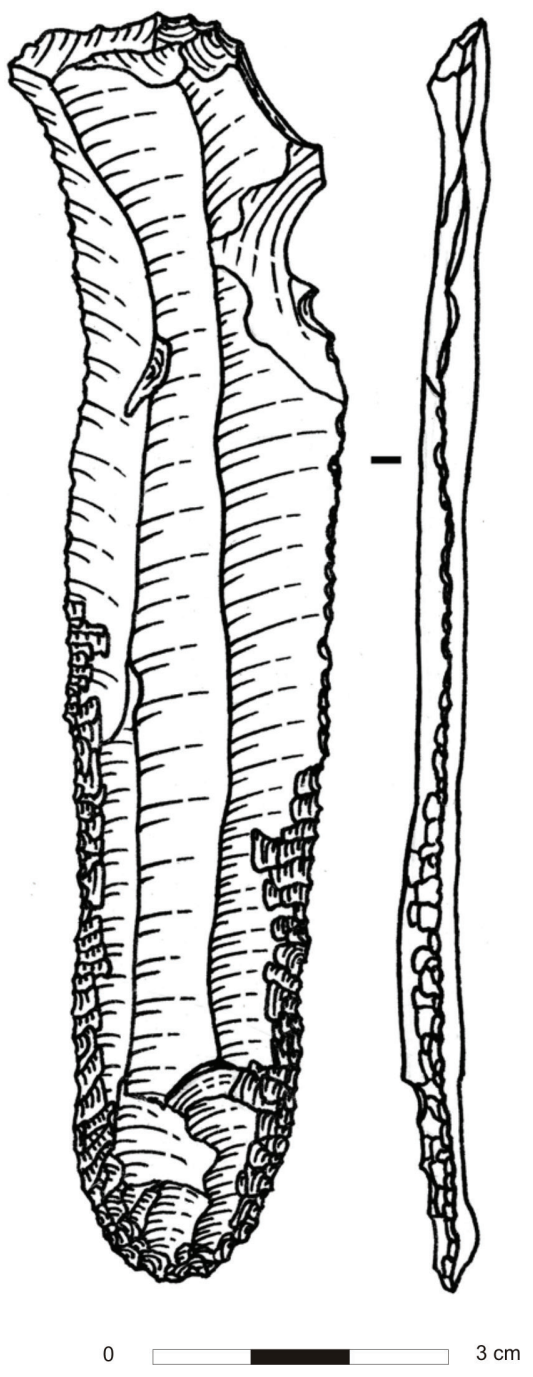

Fi g. 29 . Porohy, Yampil Region, barrow 3A. Feature 3A/15 - flint blade (localization see Fig. 28) 


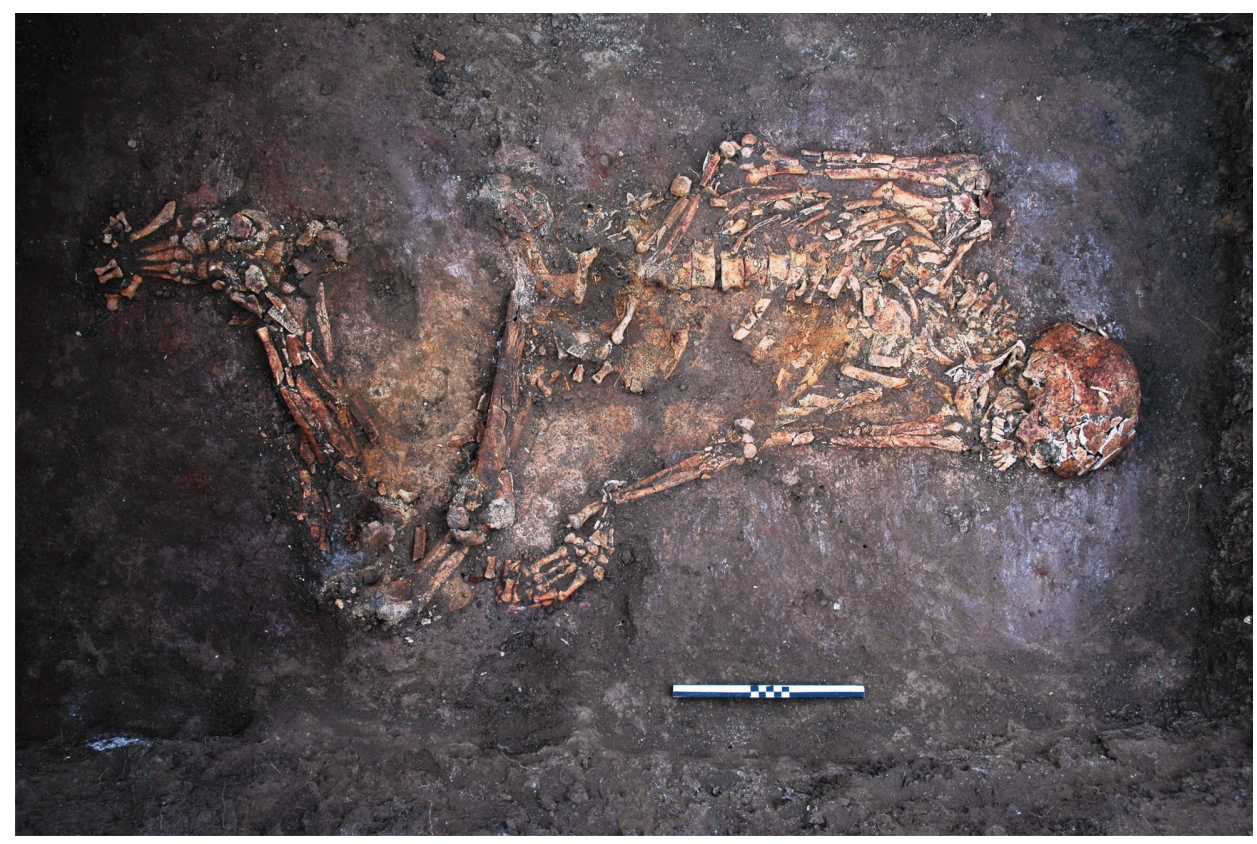

Fig. 30 . Porohy, Yampil Region, barrow 3A. Plan of feature 3A/15

Feature 3A/16

\begin{tabular}{|l|l|}
\hline Culture & Yamnaya? \\
\hline Dating & \\
\hline Structure type & Pit? Hearth? \\
\hline Size at the level of discovery & $?$ \\
\hline Size at the level of the bottom & Approx. $2.0 \times 1.2 \mathrm{~m}$ \\
\hline Depth & $0.7 \mathrm{~m}$ \\
\hline Pit orientation & W-E \\
\hline Deviation & $?$ \\
\hline Distance from barrow centre & $7.47 \mathrm{~m}$ \\
\hline Azimuth & $179^{\circ}$ \\
\hline Animal bones & Sheep/goat bone frag. \\
\hline Ritual objects & - \\
\hline Comments & \\
\hline
\end{tabular}

The feature was discovered at the SW wall of grave 15. Its outline could not be captured. On the bottom, fragments of wooden planks, single sheep/goat bones, a flint flake, ash, and charcoal were discovered (Fig. 31). 

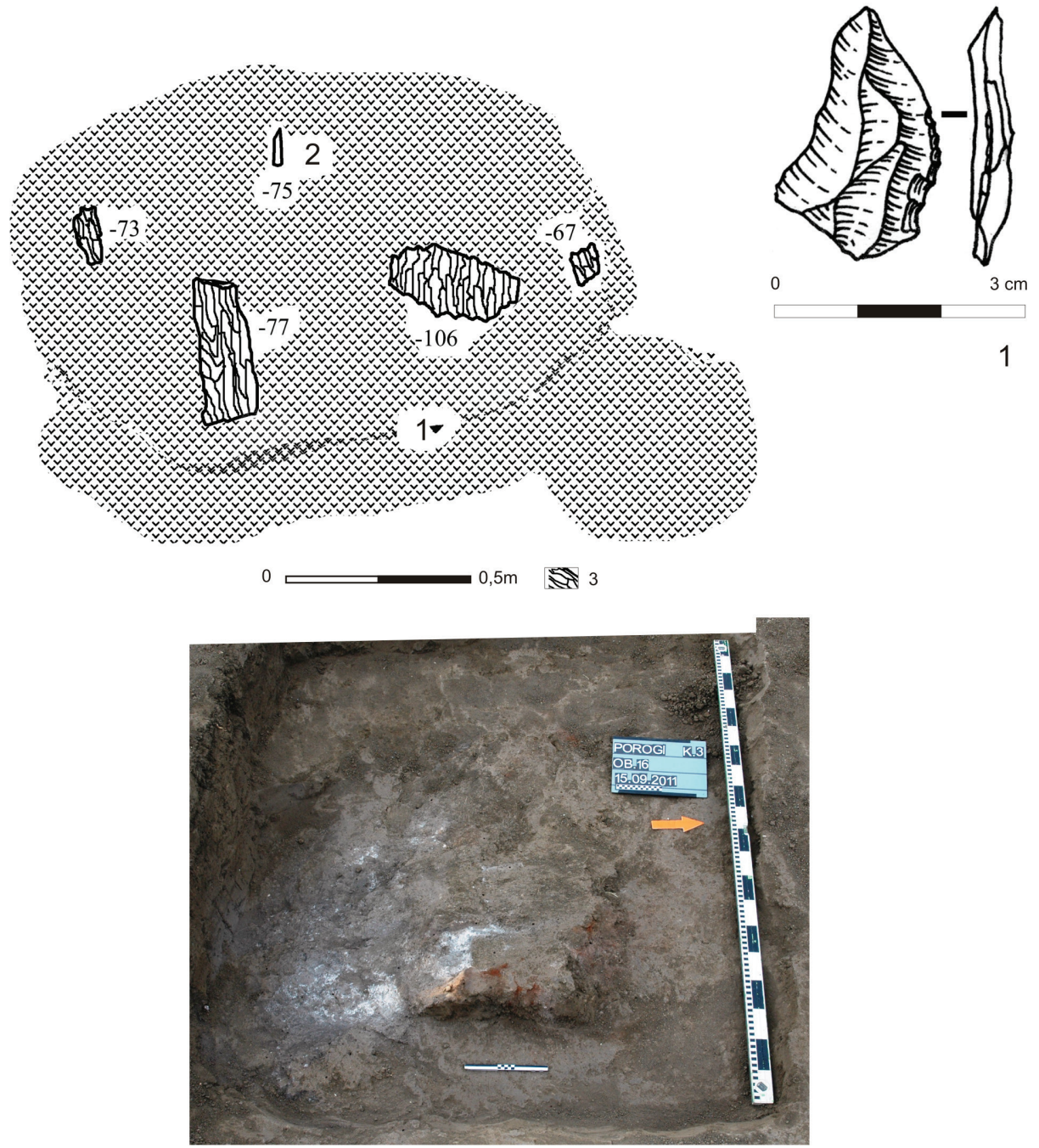

Fi g. 31 . Porohy, Yampil Region, barrow 3A. Plan of feature 3A/16: 1 - flint flake; 2 - fragments of sheep/goat limb bones; 3 - wood remains 
Feature 3A/17

\begin{tabular}{|l|l|l|l|}
\hline Culture & \multicolumn{2}{|l|}{ Yamnaya } & \multicolumn{2}{l|}{ Poz-47743: $4050 \pm 35$ BP; Poz-74394: 3930 \pm 35 BP (human bones) } \\
\hline Dating & Pit & Sex & Male \\
\hline Grave pit & 1 & Age & $30-35$ years \\
\hline Structure type & Orientation & NW-SE \\
\hline Number of burials & $2.05 \times 1.9 \mathrm{~m}$ & Deviation & $18^{\circ} \mathrm{N}$ \\
\hline $\begin{array}{l}\text { Size at the level of } \\
\text { discovery }\end{array}$ & $1.6 \times 1.05 \mathrm{~m}$ & Arrangement of head & L \\
\hline $\begin{array}{l}\text { Size at the level of } \\
\text { the bottom }\end{array}$ & $1.4 \mathrm{~m}$ & Arrangement of trunk & L \\
\hline Depth & NW-SE & Upper limbs & A \\
\hline Pit orientation & $0^{\circ}$ & Lower limbs & 5 \\
\hline Deviation & $6.25 \mathrm{~m}$ & Ochre & + \\
\hline $\begin{array}{l}\text { Distance from barrow } \\
\text { centre }\end{array}$ & $20^{\circ}$ & Presence of mat & + \\
\hline Azimuth & + & Animal bones & $\begin{array}{l}\text { Two skulls and limb } \\
\text { fragments of domesti- } \\
\text { cated goats }\end{array}$ \\
\hline Wooden roofing & Perpendicular & Ritual objects & Retouched flake \\
\hline $\begin{array}{l}\text { Roofing element } \\
\text { orientation }\end{array}$ & - & & \\
\hline $\begin{array}{l}\text { Other structural } \\
\text { elements }\end{array}$ & & & \\
\hline Comments & & & \\
\hline
\end{tabular}

The grave was sunk into the SW part of the mound. At the level of discovery, it was rectangular. A step leading to the grave chamber was located at a depth of $0.75 \mathrm{~m}$. The chamber was regularly rectangular and $0.65 \mathrm{~m}$ deep. Its roofing was made from 9-10 wooden planks up to $0.25 \mathrm{~m}$ wide. On their remains, in the NW corner of the grave, two skulls of domesticated goats were discovered (male and female; mandibles were missing). Next to the skulls, there also lay fragments of goat limbs, belonging, respectively, to two and three adult individuals. On the pit bottom, the skeleton of an adult male lay crouched on the left side. Under his left scapula, a concentration of ochre was recorded, measuring $0.2 \times 0.1 \mathrm{~m}$. At the right arm, a flint flake was found (Figs. 32-34).

\section{Grave goods}

1. Retouched flint flake (Fig. 32: 1).

2. Concentration of ochre (originally a lump?) (Fig. 32: 2). 


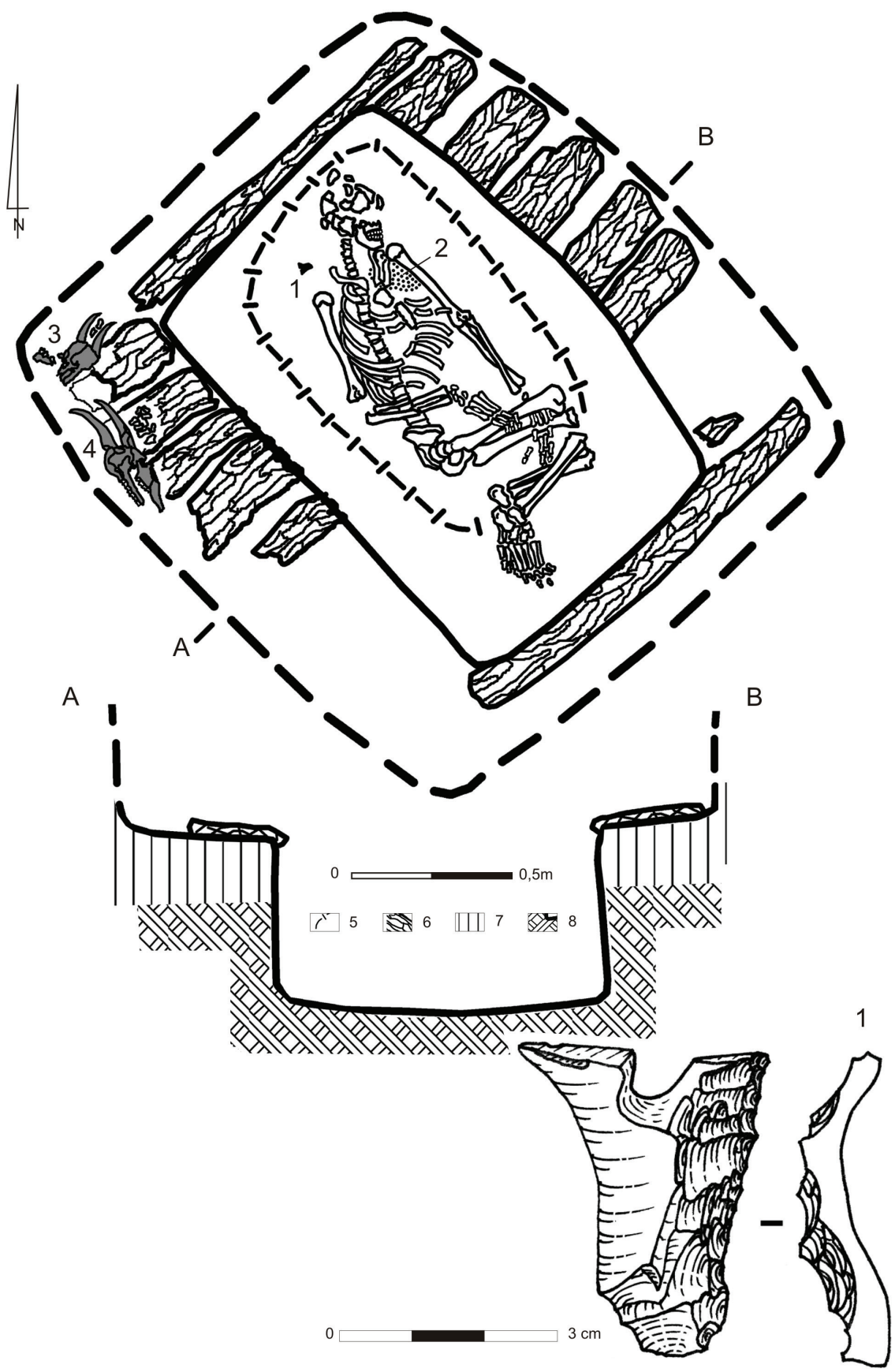

Fig. 32. Porohy, Yampil Region, barrow 3A. Plan and profile of feature 3A/17: 1 - flint flake; 2 - concentration of ochre; 3 - goat skull and hoofs; 4 - male goat skull and hoofs; 5 - outline of mat; 6 - wood remains; 7 - layer under the barrow mound; 8 - sterile soil 


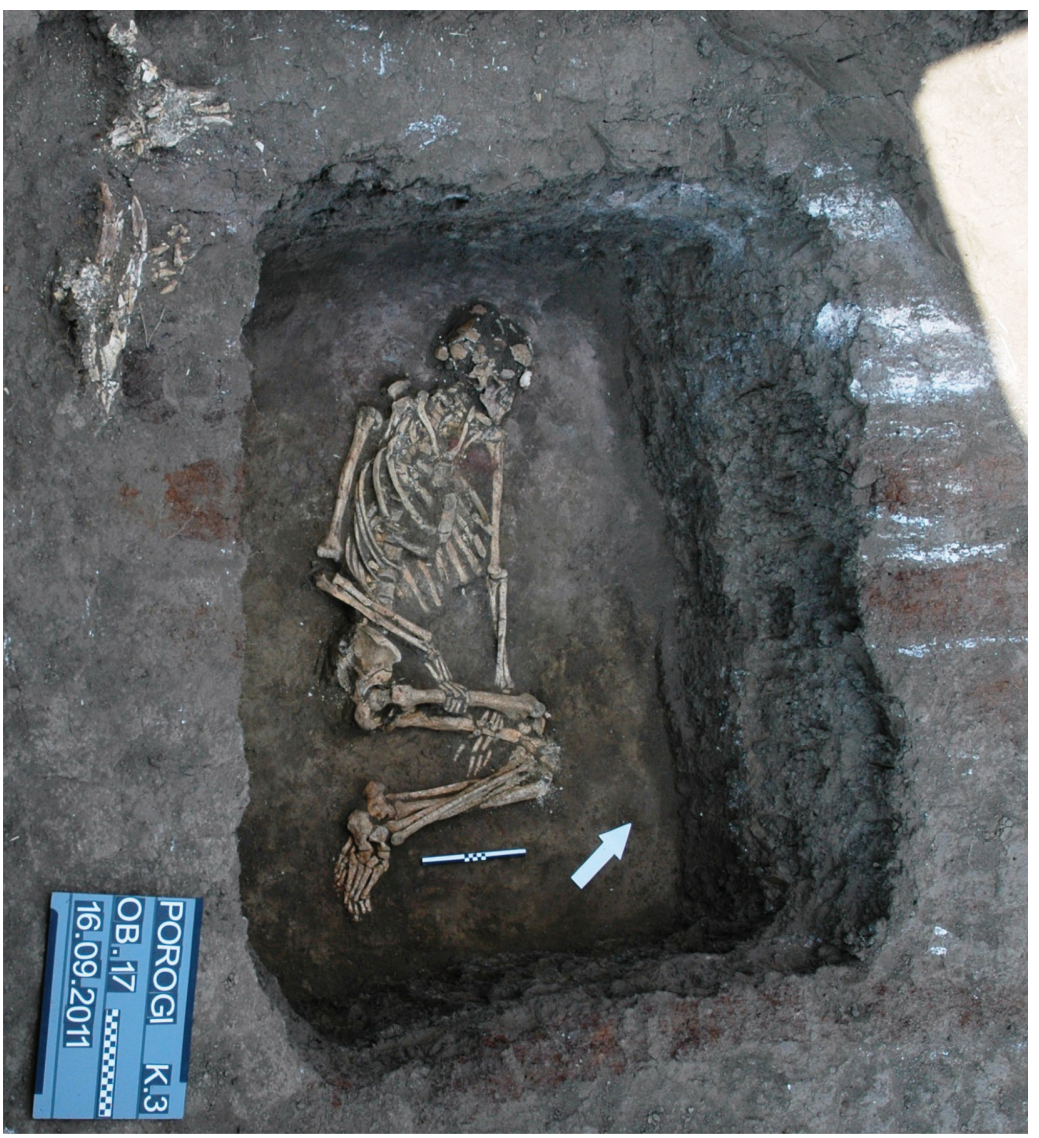

Fi g. 33 . Porohy, Yampil Region, barrow 3A. Plan of feature 3A/17

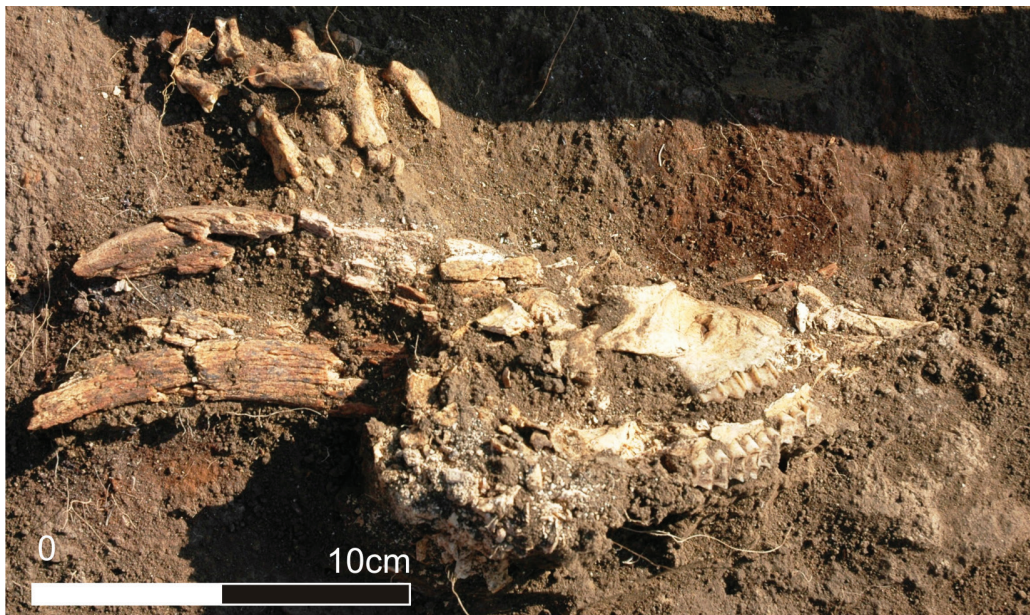

Fig. 34 . Porohy, Yampil Region, barrow 3A. Feature 3A/17: male goat skull and hoofs 
Feature 3A/18

\begin{tabular}{|c|c|c|c|}
\hline Culture & \multicolumn{3}{|l|}{ Eneolithic (?) } \\
\hline \multicolumn{4}{|l|}{ Dating } \\
\hline \multicolumn{2}{|l|}{ Grave pit } & \multicolumn{2}{|l|}{ Burial } \\
\hline Structure type & Pit & Sex & $?$ \\
\hline Number of burials & 1 & Age & Infans I \\
\hline $\begin{array}{l}\text { Size at the level } \\
\text { of discovery }\end{array}$ & $?$ & Orientation & SW-NE? \\
\hline $\begin{array}{l}\text { Size at the level } \\
\text { of the bottom }\end{array}$ & $0.9 \times 0.7 \mathrm{~m}$ & Deviation & $?$ \\
\hline Depth & $1.5 \mathrm{~m}$ & Arrangement of head & $?$ \\
\hline Pit orientation & NE-SW & Arrangement of trunk & $?$ \\
\hline Deviation & $15^{\circ} \mathrm{S}$ & Upper limbs & $?$ \\
\hline $\begin{array}{l}\text { Distance from barrow } \\
\text { centre }\end{array}$ & $11.05 \mathrm{~m}$ & Lower limbs & $?$ \\
\hline Azimuth & $158^{\circ}$ & Ochre & + \\
\hline Wooden roofing & + & Presence of mat & + \\
\hline $\begin{array}{l}\text { Roofing element } \\
\text { orientation }\end{array}$ & & Animal bones & - \\
\hline $\begin{array}{l}\text { Other structural } \\
\text { elements }\end{array}$ & - & Ritual objects & Vessel next to the skull \\
\hline Comments & & & \\
\hline
\end{tabular}

The grave was sunk into the southern part of the mound. The pit was rectangular and had rounded corners. Its fill was found to contain the fragments of wooden roofing elements. In the SW part, a discovery was made of child bone fragments, while in the southern portion, a lump of bright red ochre, measuring $6.0 \times 4.0 \mathrm{~cm}$ was found. In turn, a concentration of red-brown ochre, $4.0 \mathrm{~cm}$ in diameter, was located in the central part. In the NW corner of the feature, a vessel lay (Fig. 35).

Grave goods

1. Small straight-walled vessel with a flat bottom. Its outer surface is even, mat with traces of burnishing. The clay contains temper of crushed ceramics. Dimensions: height $-9.0 \mathrm{~cm}$, lip diameter $-11.0 \mathrm{~cm}$, bottom diameter $-6.0 \mathrm{~cm}$ (Fig. 35: 1).

2. Lump of ochre (Fig. 35: 4). 

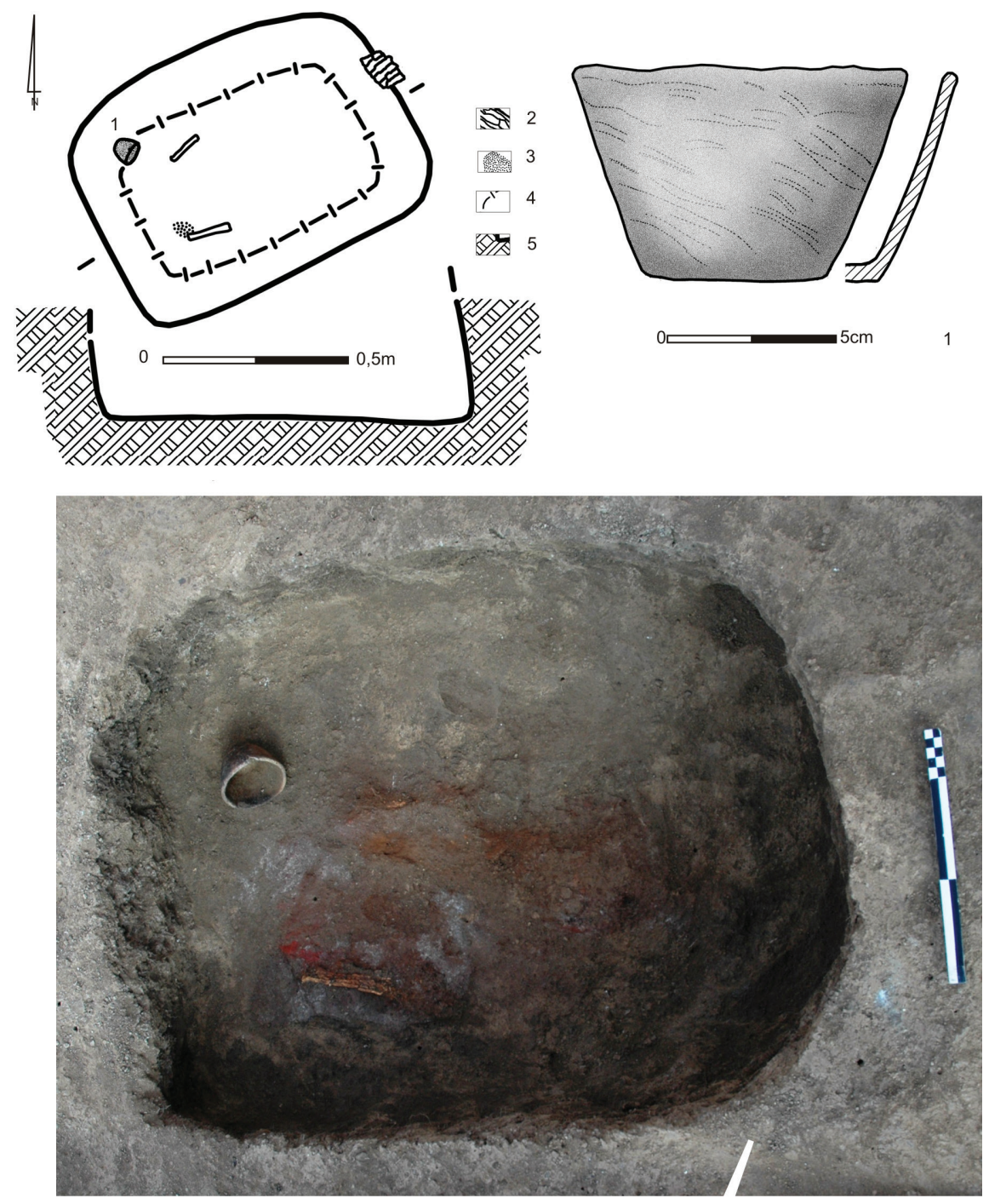

Fig. 35 . Porohy, Yampil Region, barrow 3A. Plan and profile of feature 3A/18: 1 - ceramic vessel; 2 - wood remains; 3 - ochre; 4 - outline of mat; 5 - sterile soil 
Feature 3A/19

\begin{tabular}{|c|c|c|c|}
\hline Culture & \multicolumn{3}{|l|}{ Yamnaya } \\
\hline Dating & \multicolumn{3}{|c|}{ Poz-70665: $4184 \pm 35$ BP (human bone) } \\
\hline \multicolumn{2}{|l|}{ Grave pit } & \multicolumn{2}{|l|}{ Burial } \\
\hline Structure type & Pit & Sex & \\
\hline Number of burials & 1 & Age & Below 18 months \\
\hline $\begin{array}{l}\text { Size at the level } \\
\text { of discovery }\end{array}$ & $?$ & Orientation & W-E \\
\hline $\begin{array}{l}\text { Size at the level } \\
\text { of the bottom }\end{array}$ & $0.9 \times 0.4 \mathrm{~m}$ & Deviation & $12^{\circ} \mathrm{N}$ \\
\hline Depth & $1.35 \mathrm{~m}$ & Arrangement of head & Face up \\
\hline Pit orientation & W-E & Arrangement of trunk & Supine \\
\hline Deviation & $19^{\circ} \mathrm{S}$ & Upper limbs & $\mathrm{F} ?$ \\
\hline $\begin{array}{l}\text { Distance from barrow } \\
\text { centre }\end{array}$ & $7.7 \mathrm{~m}$ & Lower limbs & $?$ \\
\hline Azimuth & $207^{\circ}$ & Ochre & + \\
\hline Wooden roofing & + & Presence of mat & + \\
\hline $\begin{array}{l}\text { Roofing element } \\
\text { orientation }\end{array}$ & $?$ & Animal bones & - \\
\hline $\begin{array}{l}\text { Other structural } \\
\text { elements }\end{array}$ & - & Ritual objects & - \\
\hline Comments & & & \\
\hline
\end{tabular}

The grave was sunk into the SW part of the mound. The pit was subrectangular. Its fill was found to contain wood fragments which were likely the remains of a roofing. On the bottom, there lay supine the skeleton of a child slightly turned to the left side. The skull bones bore traces of colouring with ochre (Fig. 36).
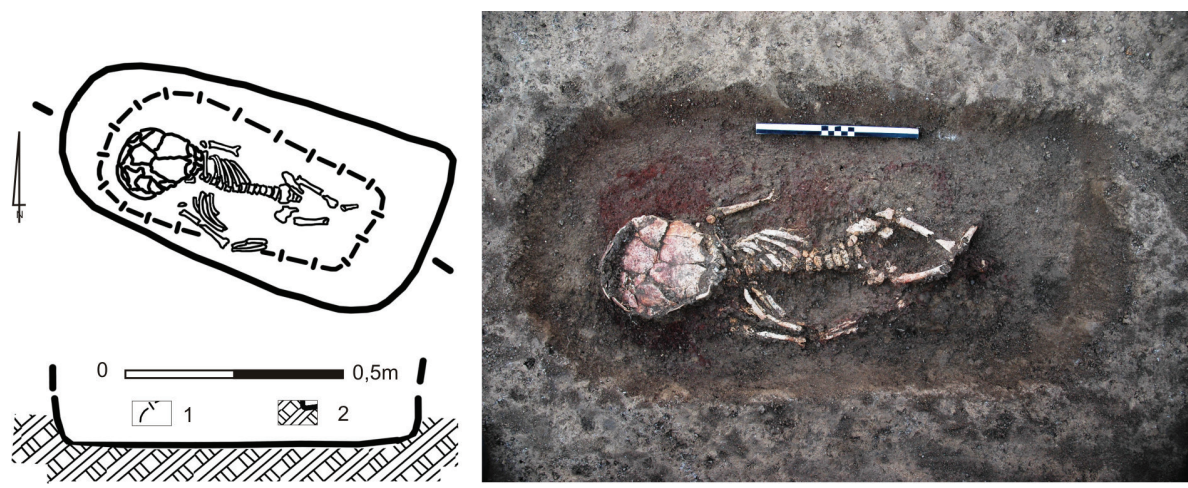

Fig. 36. Porohy, Yampil Region, barrow 3A. Plan and profile of feature 3A/19: 1 - outline of mat; 2 - sterile soil 


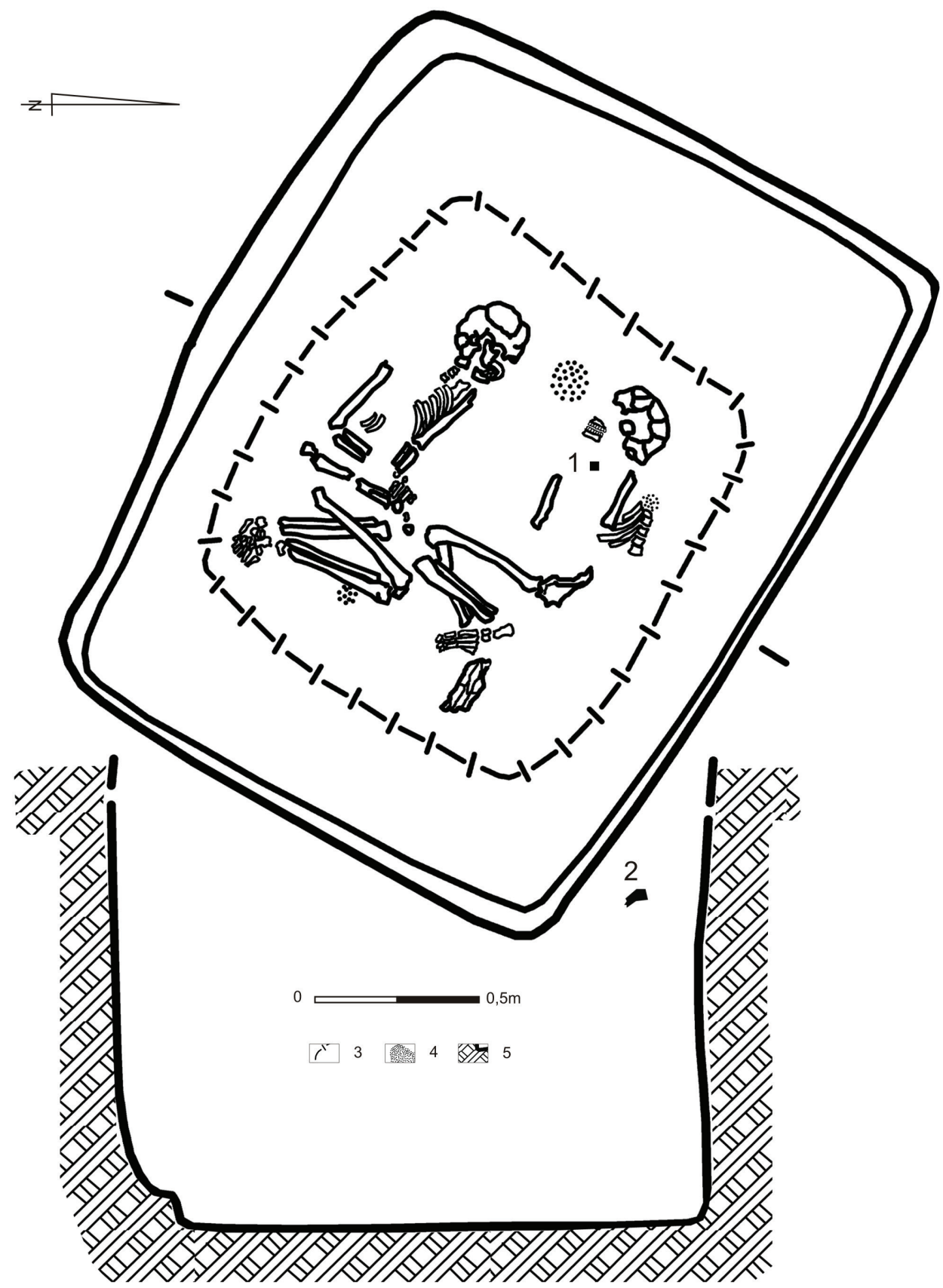

Fig. 37. Porohy, Yampil Region, barrow 3A. Plan and profile of feature 3A/20: 1 - charcoal; 2 - flint tool; 3 - outline of mat; 4 - ochre; 5 - sterile soil 

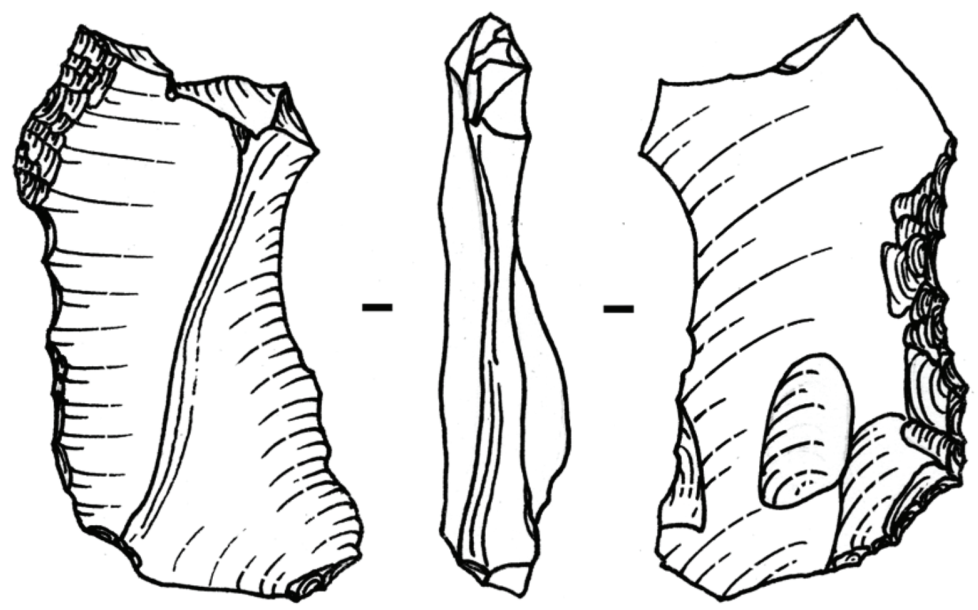

0

$3 \mathrm{~cm}$

Fig. 38 . Porohy, Yampil Region, barrow 3A. Feature 3A/20 - flint tool (localization see Fig. 37)

Feature $3 A / 20$

\begin{tabular}{|c|c|c|c|}
\hline Culture & \multicolumn{3}{|l|}{ Yamnaya } \\
\hline Dating & \multicolumn{3}{|c|}{$\begin{array}{l}\text { Ki-17385: } 3820 \pm 80 \mathrm{BP} ; \text { Poz-74397: } 4175 \pm 35 \mathrm{BP} \\
\text { Poz-47744: } 4190 \pm 35 \text { BP (human bones) }\end{array}$} \\
\hline \multicolumn{2}{|l|}{ Grave pit } & \multicolumn{2}{|l|}{ Burial } \\
\hline Structure type & Pit & Sex & $\begin{array}{l}1-\text { Male? } \\
2-?\end{array}$ \\
\hline Number of burials & 2 & Age & $\begin{array}{l}1-50-55 \text { years } \\
2-\text { Adultus-Maturus }\end{array}$ \\
\hline $\begin{array}{l}\text { Size at the level } \\
\text { of discovery }\end{array}$ & $2.45 \times 1.95 \mathrm{~m}$ & Orientation & $\begin{array}{l}1-\mathrm{NW}-\mathrm{SE} \\
2-\mathrm{NW}-\mathrm{SE}\end{array}$ \\
\hline $\begin{array}{l}\text { Size at the level } \\
\text { of the bottom }\end{array}$ & $2.30 \times 1.75 \mathrm{~m}$ & Deviation & $\begin{array}{l}1-0^{\circ} \\
2-0^{\circ}\end{array}$ \\
\hline Depth & $2.60 \mathrm{~m}$ & Arrangement of head & $\begin{array}{l}1-\mathrm{L} \\
2-\mathrm{P}\end{array}$ \\
\hline Pit orientation & NW-SE & Arrangement of trunk & $\begin{array}{l}1-\mathrm{L} \\
2-\mathrm{P}\end{array}$ \\
\hline Deviation & $17^{\circ} \mathrm{E}$ & Upper limbs & $\begin{array}{l}1-\mathrm{A} \\
2-?\end{array}$ \\
\hline $\begin{array}{l}\text { Distance from barrow } \\
\text { centre }\end{array}$ & $11.58 \mathrm{~m}$ & Lower limbs & $\begin{array}{l}1-5 / 2 \\
2-5 ?\end{array}$ \\
\hline Azimuth & $214^{\circ}$ & Ochre & + \\
\hline Wooden roofing & + & Presence of mat & + \\
\hline $\begin{array}{l}\text { Roofing element } \\
\text { orientation }\end{array}$ & Longitudinal & Animal bones & - \\
\hline
\end{tabular}




\begin{tabular}{|l|l|l|l|}
\hline $\begin{array}{l}\text { Other structural } \\
\text { elements }\end{array}$ & - & Ritual objects & Retouched flake (?) \\
\hline Comments & \multicolumn{2}{|l}{} \\
\hline
\end{tabular}

The grave was sunk into the SW part of the mound. It was accompanied by a spill of yellow loess up to $0.4 \mathrm{~m}$ thick. Underneath its western portion, a flint tool was found. The pit was rectangular and its fill contained wooden roofing fragments, suggesting that the roofing had been oriented longitudinally to the longer grave axis. On the pit bottom, a double burial was exposed: a male aged Maturus-Senilis

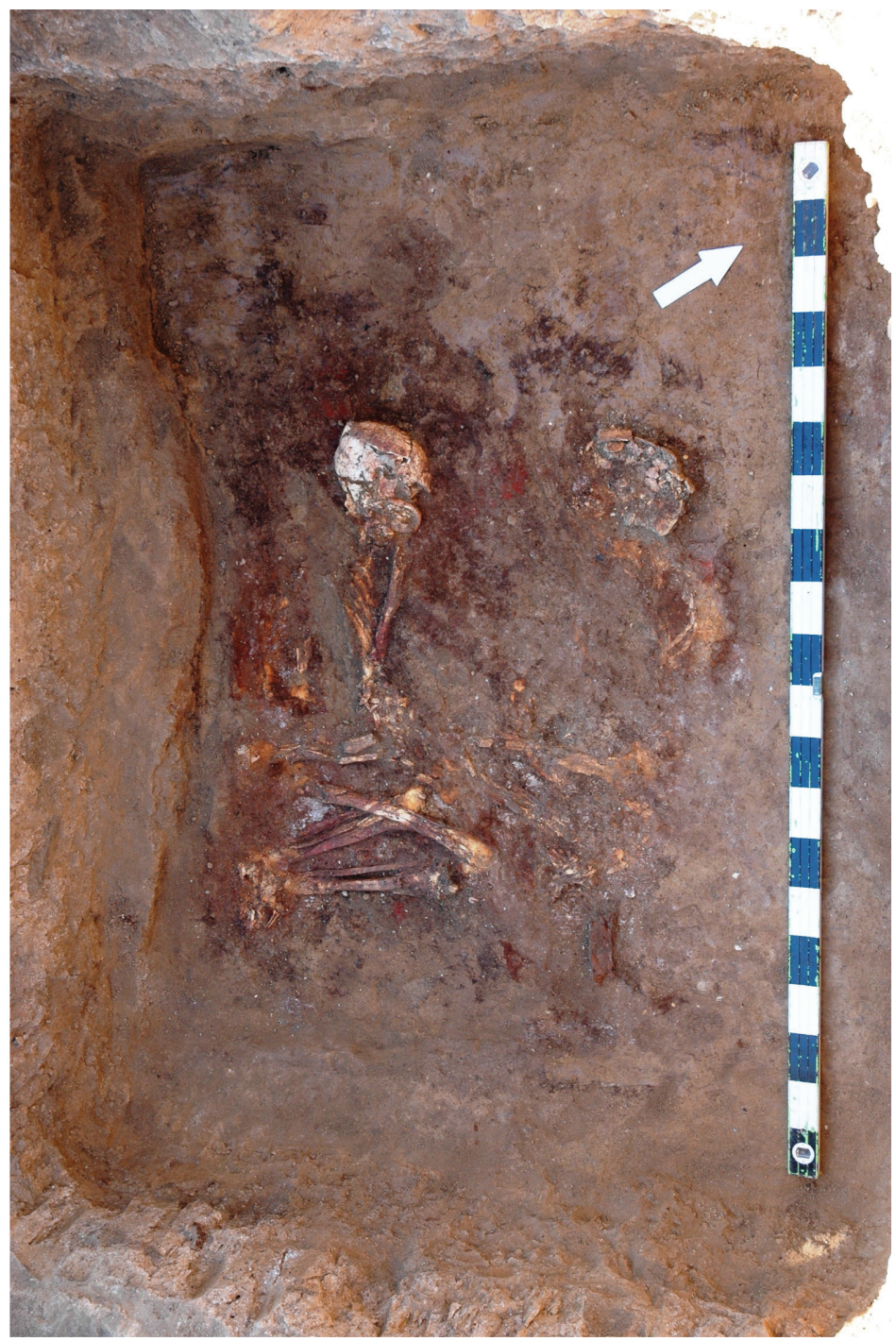

Fig. 39. Porohy, Yampil Region, barrow 3A. Plan of feature 3A/20 
lay on the left side and an individual of indeterminate sex aged Adultus-Maturus lay on the right side. At the right knee of the skeleton of the male, a concentration of ochre, $5.0 \mathrm{~cm}$ in diameter was recorded; another concentration of a similar substance (12.0 cm in diameter) was located between the skulls (Figs. 37-39).

\section{Grave goods}

1. Sidescraper on a massive flake (Fig. 38)

2. Two ochre concentrations (Figs. 37: 4, 39)

Feature $3 A / 22$

\begin{tabular}{|c|c|c|c|}
\hline Culture & \multicolumn{3}{|l|}{ Noua } \\
\hline Dating & \multicolumn{3}{|c|}{ Ki-17478: $3260 \pm 50$ BP; Poz-70666: $3380 \pm 35$ BP; (human bones) } \\
\hline \multicolumn{2}{|l|}{ Grave pit } & \multicolumn{2}{|l|}{ Burial } \\
\hline Structure type & Pit & Sex & Male \\
\hline Number of burials & 1 & Age & $30-35$ years \\
\hline $\begin{array}{l}\text { Size at the level } \\
\text { of discovery }\end{array}$ & $?$ & Orientation & NE-SW \\
\hline $\begin{array}{l}\text { Size at the level } \\
\text { of the bottom }\end{array}$ & $1.45 \times 0.80 \mathrm{~m}$ & Deviation & $17^{\circ} \mathrm{N}$ \\
\hline Depth & $1.05 \mathrm{~m}$ & Arrangement of head & $\mathrm{L}$ \\
\hline Pit orientation & NE-SW & Arrangement of trunk & $\mathrm{L}$ \\
\hline Deviation & $20^{\circ} \mathrm{N}$ & Upper limbs & $\mathrm{D} ?$ \\
\hline $\begin{array}{l}\text { Distance from barrow } \\
\text { centre }\end{array}$ & $14.07 \mathrm{~m}$ & Lower limbs & 1 \\
\hline Azimuth & $131^{\circ}$ & Ochre & - \\
\hline Wooden roofing & - & Presence of mat & - \\
\hline $\begin{array}{l}\text { Roofing element } \\
\text { orientation }\end{array}$ & & Animal bones & Frag. of a horse spine \\
\hline $\begin{array}{l}\text { Other structural } \\
\text { elements }\end{array}$ & - & Ritual objects & $\begin{array}{l}\text { Vessel next to hands } \\
\text { and face }\end{array}$ \\
\hline Comments & & & \\
\hline
\end{tabular}

The feature was sunk into the SE edge of the mound. The pit outline could not be captured. On the bottom, there lay the skeleton of a male crouched on the left side. At the bones of the hands, turned towards the face, there lay the vertebrae and the sacral bone of a young domesticated horse and a broken vessel (Fig. 40).

Grave goods

1. Small barrel-like vessel with a slightly marked lip and bottom. The outer surface is even, mat and has traces of burnishing. The clay contains temper of crushed ceramics. Dimensions: height $-8.0 \mathrm{~cm}$, bottom diameter $-6.0 \mathrm{~cm}$, mouth diameter $-9.0 \mathrm{~cm}$ (Fig. 40: 2). 


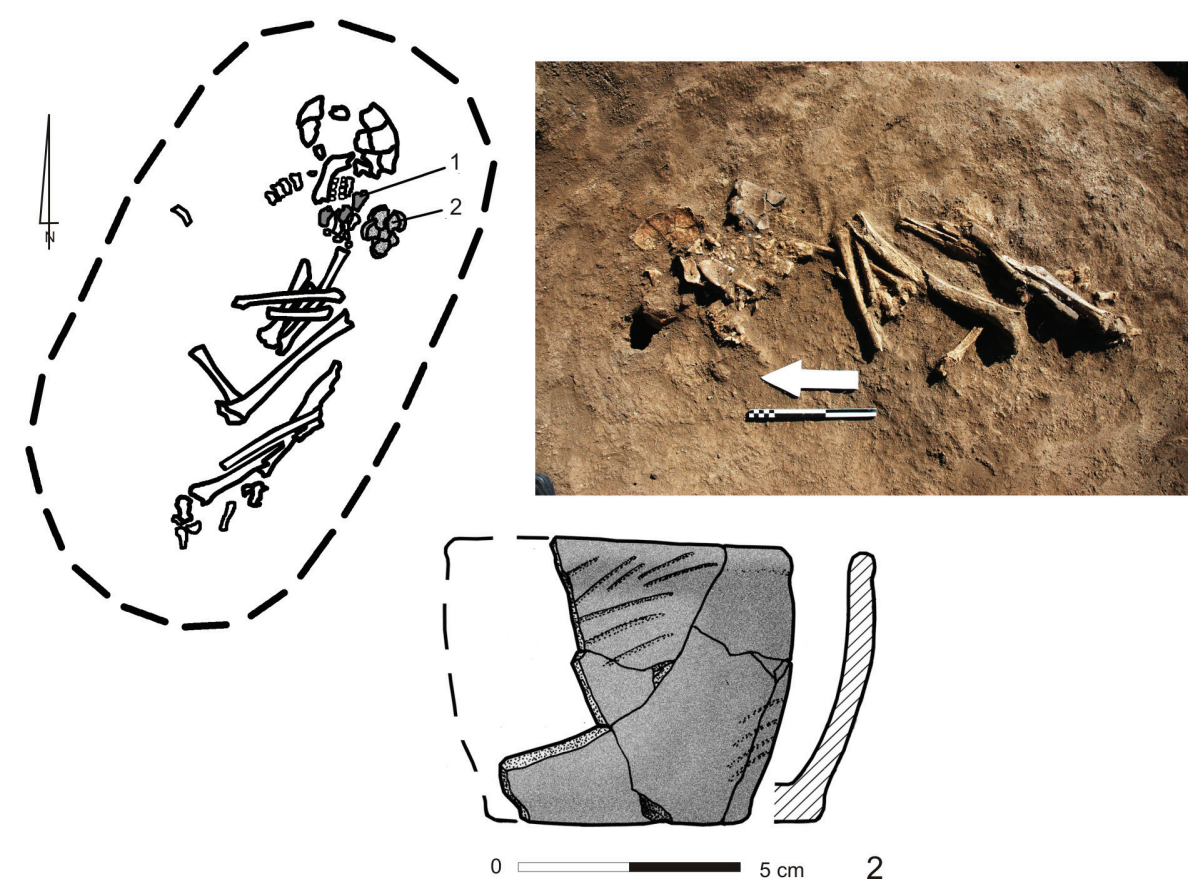

Fig. 40 . Porohy, Yampil Region, barrow 3A. Plan and profile of feature 3A/22: 1 - horse sacral bone; 2 - ceramic vessel

\section{POROHY 3A: RADIOCARBON CHRONOMETRY}

The result of the investigations carried out at Porohy $3 \mathrm{~A}$ is the documentation of a barrow ceremonial-funeral site set up (as can be judged from the horizontal distribution pattern, stratigraphy and funeral typo-chronological evidence) at the period of transition from the Eneolithic to the Early Bronze Age - in the late 4th and early 3rd millennia BC. Most likely this was expanded later, namely in the first half of the 3rd millennium BC by Early Bronze YC populations only to be converted into a $\mathrm{NC}$ necropolis around the middle of the 2nd millennium $\mathrm{BC}$.

The study of the radiocarbon chronometry of the ceremonial-funeral centre made use of 25 bone samples taken from graves. The results and their interpretation standards as far as comparative analyses are concerned have been presented in a separate paper devoted to the study of the radiocarbon chronometry of all Yampil ceremonial centres, associated with 'barrow cultures' related to the Eneolithic and the Bronze Age [Goslar et al. 2015]. The conclusions drawn there and concerning the Porohy centre can be summarized as follows: 
Stage $\mathbf{I}=$ Eneolithic/Early Bronze barrow? (features 3A/7, 3A/14, 3A/18 and possibly $3 \mathrm{~A} / 6$ and $3 \mathrm{~A} / 13$ ) most likely built in the late 4th and early 3rd millennia $\mathrm{BC}$ (a credible $14 \mathrm{C}$ measurement is not available).

Stage II = YC barrow (features 3A/1, 3A/2, 3A/10, 3A/11, 3A/12, 3A/15, $3 \mathrm{~A} / 16,3 \mathrm{~A} / 17,3 \mathrm{~A} / 19$ and $3 \mathrm{~A} / 20$ ) built ca. 2760-2515 BC.

Stage III $=\mathrm{NC}$ graves (features $3 \mathrm{~A} / 3,3 \mathrm{~A} / 5,3 \mathrm{~A} / 8$ and $3 \mathrm{~A} / 22$ ) dug into the mound and at the foot of the YC barrow ca. 1713-1464 BC.

When evaluating the scope of the above chronometric findings concerning the ceremonial-funeral centre, it is worthwhile to take note of data collection limitations encountered in exploring the site surface and its neighbouring 'ritual concepts' (barrows). First and foremost, any interpretation is hampered by the destruction of the barrow top in historical times (between 1933 and 2011 to mention a brief period, the barrow was levelled off by as much as $2.50 \mathrm{~m}$ ). This fact greatly restricts any credible stratigraphic analysis of 'younger YC mounds', representing stage II of the 'barrow architecture' development. Secondly, it is not possible to place the Porohy $3 \mathrm{~A}$ (locality of cult) in the methodologically corresponding chronology of the "ceremonial centre Porohy - Tsari" [see Ch. 1; Potupczyk, Razumov 2014: Fig. 1.2.:2; Harat et al. 2014: 70ff].

4. POROHY CEREMONIAL CENTRE: RITUAL AND TAXONOMIC-TOPOGENETIC ASSIGNMENT

The analysis of the horizontal distribution pattern and stratigraphy makes for distinguishing within the feature a sequence of two barrow cemeteries and a flat cemetery sunk into its edge and culmination. The cemeteries are linked to the communities of the Eneolithic (?) and the Early and Late Bronze Ages.

The initial taxonomic assignment of the features, presented in the field investigation report [Razumov et al. 2012; see also Razumov et al. 2012b], relied on cultural classifications by S. Razumov made after consultations in the Dept. of the Eneolithic and Bronze Age, Ukrainian National Academy of Sciences, Kyiv. The report mentioned two taxa: YC and the Babyno culture (BC). Later corrections, introduced after 2014, relied on an expanded range of typo-chronologically admissible cultural classifications. The analyses focused on the perspectives of ritual references concerning funerary architecture and funeral and post-funeral behaviour in an attempt to distinguish an 'older' - 'Eneolithic' - level in the set of features/graves classified as 'Yamnaya' (S.V. Ivanova) and exclude from the identification framework 'Babyno-type' features in favour of including NC ones (V.I. Klochko) [see Ivanova, Toschev 2015; 2015a]. 
The radiocarbon chronometry of burials recorded on the Porohy $3 \mathrm{~A}$ site has not always corroborated the corrections made (see Ch. 3: no diagnostic date is available for stage I, in particular for feature 3A/14).

\subsection{STAGE I: ENEOLITHIC/EARLY BRONZE AGE}

By studying profile baulks, two major construction phases of barrow 3A in Porohy were distinguished. To determine the time when the oldest mound was built (see stage I) - erected over feature 3A/14 - is difficult due to the secondary destruction of the central feature and the major transformation of the older structure in the course of the later stages of barrow modification. To make matters worse, there is no conclusive evidence such as movable finds and fully diagnostic manifestations of funerary rites or any credible radiocarbon measurements. An attempt to date bones from the fill of grave $3 \mathrm{~A} / 14$ produced a result most likely unrelated to the time of construction of this feature [Goslar et al. 2015]. The presence of a stone cromlech as well as special 'ritual' structures ('postholes' in the $\mathrm{N}$ part of the mound) find analogies in barrows dated to the Eneolithic [Yarovoy 2001; Potemkina 2004]. The stratigraphic arguments referring to the spills of yellow loess clearly showed that, pointing to the north, two large postholes (features 3A/6 and 3A/13) had been sunk into the stratum of the older mound. Hence, they were undeniably younger than grave $3 \mathrm{~A} / 14$. Whereas their relationship to the burial related to the building of the younger mound (over grave $3 \mathrm{~A} / 2$ ?) is harder to define. The wooden structures could have been connected to the presence of the cromlech or possibly to the erection of the stone stela, too (at the time of discovery located at the fringe of the older mound, an azimuth of about 30 degrees).

A similar stratigraphic situation was recorded in the case of barrow 1 in Mocra, Rybniţa Region, also in Podolia, where postholes were sunk into the edge of the first mound [Kashuba et al. 2001-2002: 220]. In this case, too, the structures of central graves and the barrow itself do not support its linking with any certainty to either the YC or the groups of the Eneolithic. With the Porohy barrow being dated to the very beginning of the 3rd millennium $\mathrm{BC}$, some syncretism of cultural traditions, however, can also be assumed and the presence of a rite with some elements of Eneolithic traditions in the older YC phase can be expected as well [Rassamakin 2013: 127-130; Manzura 2003-2004; Ivanova 2015: 285, 286]. These questions have been discussed mostly in connection with the assessment of the role of the Usatovo group/culture in the formation of the YC variety from the north-western Black Sea Coast [Zbenovich 1974; Yarovoy 1985; Alekseeva 1992].

The height of the older mound in its central part was 0.5-0.7 m. Its upper surface was levelled off. This shape is encountered in the case of some Eneolithic 
barrows [see Klochko et al. 2015]. Alternatively, it could have been the result of a partial levelling off and remodelling preceding the superimposition of the second mound (which is less likely). Originally, the barrow was oval in shape (elongated along its N-S axis) and its maximum diameter was $24.0 \mathrm{~m}$. On the recorded profiles, a ditch, $5.0 \mathrm{~m}$ wide and $0.4 \mathrm{~m}$ deep, is seen to have encircled the barrow and must have been related to the construction of the barrow mound.

Grave 14 was almost completely destroyed by a modern-day robber trench, most likely at the end of the 20th century. Around it, despite the fact that the original level has been preserved quite well, no spills of yellow loess have been recorded, which must have been left behind after the pit had been dug. Hence, it is considered to hold the oldest chronological position after taking into account other stratigraphic considerations and the very depth of the pit. The fill of feature 3A/14 was found to contain single human bones. Their anthropological analysis showed them to be the bones of a child and an adult individual. Some of these bones may have come from other burials destroyed by the robber trench, that is above all from grave 2 (burial of an adult male). First of all, to the oldest burial, the single bones of a child could be linked (all anthropological references in this paper are taken from Lytvinova et al. 2015). This question can possibly be explained in the future using archaeometric analyses.

The fill of feature 14 yielded also two lip fragments of a large pot with a relief strip at the lip edge. The technological characteristics of this vessel, including its thick walls and a large size, suggest its Eneolithic provenance (phase C/II of the Tripolye culture, the Gordineşti/Kasperovtsy - Horodiştea/Erbiceni complex?). A link of this type of pottery to the central grave cannot be excluded. The other objects from the fill (deer and sheep/goat bone fragments, fragment of a deer antler tool, and a hammerstone) do not provide any arguments in the attempts to make cultural-chronological distinctions or concretizations.

The child pit grave $3 / 18$, located on the southern fringe of the oldest mound, is connected with the Eneolithic too. Its structural characteristics and depth show that the grave was sunk into the original ground level, prior to the building of the barrow. This situation has analogies on other Late Eneolithic sites such as Pidlisivka [Klochko et al. 2015a], Severynivka, barrow 2 [Harat et al. 2014] and Bursuceni [Yarovoy 1978]. From grave 3A/18, a small conical vessel was recovered. This form is encountered in both YC features and older 'Eneolithic' graves [see Dergachev 1986: 51, Fig. 11: 1-10; Yarovoy 1985; 85, 86, Fig. 20: 1; Ivanova 2010, Figs. 3.40, 3.41]. 
Central grave. Located in the central part of the barrow, grave $3 \mathrm{~A} / 2$ was damaged by a robber trench. For this reason, it is hard to establish the details of its structure and the burial arrangement. Nevertheless, what could be recorded includes skull fragments and those of an upper limb together with the right portion of the shoulder girdle of an adult individual (probably male), a mat of organic raw material and the traces of colouring the skeleton with ochre. These traits and the obtained radiocarbon measurement argue strongly in favour of associating grave $3 \mathrm{~A} / 2$ with the YC complex. The outline of the feature was barely visible, but most likely it was a simple pit without a step. The characteristics of the grave, as well as its location, make the case for considering it the central feature of the younger mound. Due to its advanced levelling off, it is hardly possible to assess the range of successive mound add-ons and their relationship to particular graves.

Graves sunk into the mound. Barrow 3A in Porohy stands out from the Yampil cluster as the one with the largest number of YC graves sunk into a mound (11 features). These features were oriented not in relation to the points of the compass, but with their longer axis towards the barrow centre, thus forming arches encircling the barrow centre characteristic of the Dniester-Danube YC. Interestingly enough, the principle of orienting the deceased clockwise or anticlockwise depending on their location in the barrow, observed sometimes, has not been kept in this case [Dergachev 1986: 40]. Neither is the concentration of graves in the eastern portion of a mound, found in Porohy, often encountered in the region in question.

A considerable number of $\mathrm{YC}$ graves sunk into the strata of the younger mound formed an arch, beginning with postholes $3 \mathrm{~A} / 6$ and $3 \mathrm{~A} / 13$ on the northern side. It comprised graves $3 \mathrm{~A} / 12,3 \mathrm{~A} / 10,3 \mathrm{~A} / 11,3 \mathrm{~A} / 15 / 16$ and $3 \mathrm{~A} / 17$. Outside of this arrangement, child grave $3 \mathrm{~A} / 19$ and features $3 \mathrm{~A} / 1$ and $3 \mathrm{~A} / 20$ were left. The laying out of the cemetery may have been accompanied by a barrow enlargement, which however - due to the ploughing away of the mound - could not be established. The arch arrangement of secondarily sunk graves is characteristic of the entire Dniester-Danube area [Shmagliy, Chernyakov 1970: 96; Yarovoy 1985: 57-61; Dergachev 1986: 32].

Clear traces of a mound add-on (of unspecified size) were recorded at feature 20 sunk into the SW fringe of the younger mound. On the N side, it was accompanied by the spill of yellow loess covered next with the layer of the mound. To determine the stratigraphic relationship of this grave to the above-named features, forming an arch, is not possible. Radiocarbon measurements for grave 3A/20 indicate its rather early date - despite its outermost location within the mound.

In terms of structure, grave 1, sunk into the younger mound of the barrow, stood out. The outline of a large excavation was perceptible already from the floor 
of surface soil. The grave chamber walls were boarded with longitudinally arranged planks, forming a chest construction. The boarding of side walls is a structural element characteristic of Podolia YC graves sunk into mounds. In the Yampil cluster, they were recorded in barrow 2, Porohy (graves 2/4 and 2/6), barrow IV, Prydnistryanske (graves IV/8 and IV/9), with more examples coming from barrows in Oknitssa and Mocra [Manzura et al. 1992: 89; Kashuba et al. 2001-2002: 220, 221]. In all these cases, graves with such wooden structures represent a younger chronological horizon.

Worthy of attention is the way corpses were arranged in all the YC graves sunk into the younger mound. The position on the side clearly dominated: left (6) or right (3), i.e. the positions classified as group III by Y.V. Yarovoy [1985: 48] and group III by V.A. Dergachev [1986: 37] or consistent with the third tradition, following the slightly different division by Y.Y. Rassamakin [2004; 2013: 116]. Only in one case (grave 11) was the corpse laid on its back. Due to advanced grave destruction, it is not possible to determine how the individual buried in feature 2 was deposited, probably the central feature of the younger mound. The arrangement of the preserved lower limb and scapula suggests that in this case the deceased lay supine. The consistency in laying the deceased on their side is a manifestation of the unity of the burial tradition and, perhaps, a relatively late chronological position of the graves sunk into the barrow [Yarovoy 1985: 52]. Furthermore, this is borne out by the recurrent arrangement of upper limbs, with one hand being placed around the pelvis/waist [types A and I according to Häusler 1974: 11, Abb. 1]. The arrangement was recorded in almost all burials secondarily sunk into the barrow - with the exception of feature $3 \mathrm{~A} / 7$. In this context, a notable absence is that of extended burials - with both upper limbs straightened and placed along the trunk (type F) - characteristic of the $\mathrm{YC}$, in contrast to other Yampil barrows located nearby.

In grave 3A/11, forming part of the arch described earlier, the deceased lay supine with the lower limbs arranged rhomboidly and one hand laid on the pelvic bones. This arrangement on the one hand differs from the other burials and, on the other, is characteristic of graves secondarily sunk into mounds both in the Yampil cluster and on the entire north-western Black Sea Coast. What also attracts attention in this grave is the presence of additional structural elements, namely posts in pit corners, which are characteristic above all of central graves and cemeteries sunk into mounds associated with earlier phases. Feature 3A/11, therefore, stands out among the other graves in respect of several elements of the burial tradition. However, its location in a tight cluster with several other graves argues against its slightly older chronological position.

Among Porohy 3A features, in terms of structure and corpse arrangement, a clear departure from the recurrent pattern is the burial from grave $3 \mathrm{~A} / 7$. In it, the corpse was placed on its side with limbs strongly bent at both the hips and knees, i.e. in agreement with the rules of the 'fourth burial tradition', which is rare in the 
YC rite [Rassamakin 2013: 127]. In Podolia, we know only of two other similar features: grave 1/14 from Klembivka, Yampil district, and grave II/2 from Kuzmin, Kamenka district [Bubulich, Khakheu 2001: 130, Fig. 10: A]. Grave 3A/7, as the only feature from Porohy $3 \mathrm{~A}$, holding the burial of an adult individual, had a simple structure: a pit without a step leading to the grave chamber.

Flint artefacts. In grave 3A/15, at the level of a wooden roofing, a knife insert was discovered, which had been made from a regular blade of Cretaceous Dniester flint. Tools of this kind are rarely found in YC graves [Yarovoy 1990: 85, Fig. 37: 2; Agulnikov, Sava 2004: 112], but are a frequent component of CWC inventories, including those from barrows in south-eastern Poland and the upper Dniester drainage basin [Machnik et al. 2006: 217, Fig. 18; Włodarczak 2006: 30-32; Libera 2009: 288, 291; Gancarski, Valde-Nowak 2011: 284, Fig. 5]. The occurrence of such a tool in a grave from Porohy $3 \mathrm{~A}$ may thus testify to contacts between populations living on the upper and middle Dniester [Razumov 2011: 146, 147]. This find is made even more interesting when it is considered that neighbouring barrow 2 in Porohy yielded an amphora typical of the older phase of the CWC [Harat et al. 2014: 87, Fig. 2.3.4:9; Ivanova et al. 2014: Fig. 4.3.3:1].

Flint artefacts were relatively common finds: they were recovered from six graves. Besides the retouched blade from grave 3A/15 mentioned earlier, these were flake tools: sidescrapers (features 3A/11, 3A/17 and 3A/20), a bifacially retouched arrowhead (feature $3 \mathrm{~A} / 11$ ) and flakes (features $3 \mathrm{~A} / 1$ and $3 \mathrm{~A} / 12$ ). Their recurrence in Podolia YC graves proves that individual flakes did not find their way to the fills by chance but were an element of a followed ritual. The arrowhead from grave $3 \mathrm{~A} / 11$, in turn, found among pelvic bones, indicates that the buried individual was shot and injured. The degree of flint calcification suggests, however, that the injury did not result in death but rather that the injured man lived for quite a long time with the point in his body. The finds of points causing injuries and not being elements of grave goods are frequent in YC graves [Razumov 2011: 73].

Animal bones. The only animal bones deposited in the graves were the remains of small ruminants. In two cases (graves $3 \mathrm{~A} / 11$ and $3 \mathrm{~A} / 17$ ), these were goat skulls (without mandibles), and in one case (grave 3A/10), the phalanges and hoofs of a goat/sheep were found. The skulls were placed in the corners of the wooden roofing of the grave chamber. The bones of a goat/sheep were discovered also in the robber trench in the barrow centre (grave 3A/14). From the latter feature, single deer bones and the fragments of a deer antler tool were recovered as well.

Ochre. A constant element of the funerary rite was the use of ochre. Most skeletons bore traces of this colorant (except for the female deceased from feature $3 \mathrm{~A} / 12$ ) and in eight cases, next to the heads of the deceased, its small globular or oval lumps were found.

Mats were discovered in all YC graves (9 burials), but also in three of four NC burials and in one of two graves linked to the Eneolithic. The use of rectangular 
mats made of organic substances to line the grave bottom was de rigueur. In some cases, mats were part of the grave chamber roofing as well.

As on other Podolia sites, the traces of the use of fire were also recorded in the form of hearths on the step in features $3 \mathrm{~A} / 10$ and $3 \mathrm{~A} / 16$.

The characteristics of the funerary rite outlined above lead to an interesting conclusion as to the chronological position and cultural connections of the studied materials. It is hard to assess the character of two graves exposed in barrow centres (features $3 \mathrm{~A} / 2$ and $3 \mathrm{~A} / 14$ ) due to their advanced destruction. The other $\mathrm{YC}$ graves, however, are characterized by the high incidence and domination of the elements that are not encountered or are in a minority in other Yampil cluster cemeteries or in the entire Middle Dniester Area for that matter. It can be assumed that the oldest barrow was built towards the end of the Eneolithic or in the very beginning of the Early Bronze Age. Next, it was extended in the older YC phase (feature 3A/2?). The funerary rite observed in the graves sunk into the younger mound indicates their considerably later position. Almost all the deceased were laid in the position on the side. The presence of special grave structures with the equally symptomatic absence of elements characteristic of the older phase argues in favour of the relatively late chronological position. Traits typical of the late - Budzhak - phase are not found, either (as defined by V.A. Dergachev, L.S. Klein or I.T. Chernia$\left.\operatorname{kov}^{4}\right)$. On the strength of these arguments, one could try to estimate the age of the cemetery 'on the barrow' as going back to the last centuries of the first half of the 3rd millennium BC. Moreover, the recurrence of the funerary rite traits mentioned earlier lends itself to the proposition that the cemetery was laid out according to plan by a single local group of people.

The corroboration of the above observations on the age of Porohy $3 \mathrm{~A}$ finds by radiocarbon measurements is possible only in part. A major obstacle is the inconsistency of results obtained in the Poznań and Kyiv laboratories [Goslar et al. 2015]. For the purpose of comparison with the results for three other Yampil cluster sites, the measurements made only in the former laboratory can be used. Pointing to the years ca. 2760-2515 BC, the measurements in general are consistent with the above suggestion. They are clearly younger than the oldest results obtained for the barrows in Prydnistryanske 1 and Klembivka 1. Surprisingly early, the age of graves 3A/19 and 3A/20 determined on their basis contrasts with opinions associating these features with the younger stages of the functioning of the Porohy 3 A cemetery. Leaving these results aside, only the age obtained for grave 2 (stratigraphically the oldest) is quite close to the dating of the sub-barrow features from Pidlisivka 1 - which may be a correct conclusion just as well. The other graves from Porohy 3A may be referred to the years from the interval of ca. 2650$2500 \mathrm{BC}$, i.e. to the beginnings of the 'Budzhak stage' in the nomenclature used for the north-western Black Sea Coast.

\footnotetext{
4 For a broader discussion see: Ivanova, Toschev 2015; $2015 \mathrm{a}$.
} 
Into the central and southern parts of the younger mound, 2nd-millennium$\mathrm{BC}$ graves, linked to the $\mathrm{NC}$, were sunk (features $3 \mathrm{~A} / 3$ - central part; features $3 \mathrm{~A} / 5,3 \mathrm{~A} / 8,3 \mathrm{~A} / 22$ - southern part). These are the northernmost graves of this culture discovered to this day; most NC finds come from the opposite bank of the Dniester.

In the 'conservator report', feature $3 \mathrm{~A} / 3$ was assigned to the $\mathrm{YC}$, while features $3 \mathrm{~A} / 5,3 \mathrm{~A} / 8$ and $3 \mathrm{~A} / 22$ were classified as belonging to the $\mathrm{BC}$ [Razumov et al. 2012]. This debatable, in our opinion, assessment was elaborated on in the first 'fragmentary publication' of the necropolis in question concerning burial $3 \mathrm{~A} / 5$ [Razumov et al. 2012a].

$\mathrm{NC}$ graves differ from others above all in the degree of limb bending and can hardly be told apart from BC and Sabatinovka culture features, especially in the case of burials deprived of any grave goods, which form a majority of finds [Krushelnitska 2006: 98-102]. The similarity between these burials follows probably from the role of the $\mathrm{BC}$ in the development of $\mathrm{NC}$ funerary rite, which was stressed by most researchers. In our opinion, difficulties in distinguishing between NC and Sabatinovka culture finds indicate their cultural closeness. Probably, they ought to be considered as two varieties of the same culture, which diverged in order to adapt to different natural-climatic zones: NC to the forest-steppe and foothills, while the Sabatinovka culture to the steppe. The discovery of NC graves in the Yampil district of the Vinnitsa Oblast shows that the sites of this culture are located north of the Dniester not only on its upper [Krusshelnitska 2006] but also middle course.

$$
* * *
$$

The cemeteries in the 'Tsari ceremonial complex' in Porohy are located in a particularly prominent type of landscape, owing to its immediate proximity to the Dniester. This location may explain the intensity with which they were used for ritual purposes in the Late Eneolithic, and Early and Late Bronze Ages. They were exposed, however, when they were already in the state of advanced devastation, which greatly hampered archaeometric observations and prevented the authors from continuing their interpretations. A number of local, 'incidental ritual types of behaviour', one of them being a very rare custom of tattooing the limb bones of the deceased (feature 3A/10), should provoke further, parallel research. 


\section{REFERENCES}

Agulnikov S., Sava E.

2004 Issledovaniya kurganov na levoberezhe Dnestra. Kishinev.

Alekseeva I.L.

1992 Kurgany epokhi paleometalla v Severo-Zapadnom Prichernomore. Kyiv.

Bubulich V., Khakheu V.

2001 Issledovaniya kurganov v Kamenskom rayone na levoberezhe Srednego Dnestra. In: N.A. Ketraru (Ed.) Severnoe Prichernomore ot eneolita $k$ antichnosti, 112-148. Tiraspol.

Dergachev V.A.

1986 Moldaviya i sosednie territorii v epokhu bronzy. Kishinev.

Gancarski J., Valde-Nowak P.

2011 Inwentarze ,grobowe” kultury ceramiki sznurowej w nasypach kurhanów w Karpatach. In: H. Kowalewska-Marszałek, P. Włodarczak (Eds) Kurhany i obrządek pogrzebowy w IV-II tysiącleciu p.n.e., 279-289. Kraków, Warszawa.

Goslar T., Klochko V.I., Kośko A., Włodarczak P., Żurkiewicz D.

2015 Chronometry of Late Eneolithic and 'Early Bronze' cultures in the Middle Dniester area: investigations of the Yampil Barrow Complex. In: A. Kośko (Ed.) Podolia as a Cultural Contact Area in the 4th/3rd-2nd Millennium BC. Baltic-Pontic Studies 20: 256-291.

Harat K., Potupczyk M., Razumow S.

2014 Charakterystyka źródeł archeologicznych pozyskanych w latach 1984-1993. In: A.Kośko, M. Potupczyk, S. Razumow (Eds) Naddniestrzańskie kompleksy cmentarzysk kurhanowych społeczności z III i z pierwszej polowy II tysiaclecia BC w okolicach Jampola, obwód winnicki. Z badań nad północno-zachodnią rubieża osadnictwa społeczności kregu kultur „wczesnobrazowych” strefy pontyjskiej. Badania z lat 1984-2010. Archaeologia Bimaris - Monografie 6, 45-204. Poznań.

Häusler A.

1974 Die Gräber der älteren Ockergrabkultur zwischen Ural und Dnepr. Berlin. 
Ivanova S.V.

2000 Naselennia yamnoyi kulturno-istorychnoyi spilnoty Pivnichno-Zakhidnoho Prychornomoria (doslid sotsiolohichnoyi interpretatsiyi pokhovalnykh pamiatok). Kyiv.

2013 Kulturno-istoricheskie kontakty naseleniya Severo-Zapadnogo Prichernomoria v rannem bronzovom veke: Zapad-Vostok. Kulturno-istoricheskie kontakty naseleniya. Stratum plus 2: 158-248.

2015 Protobudzhakskiy gorizont Severo-Zapadnogho Prichernomoria. Stratum plus 2: 275-294.

Iwanowa S.V., Kośko A., Włodarczak P.

2014 Komponent tradycji kultur ceramiki sznurowej. Amfory w pólnocno-zachodnio-nadczarnomorskich grobach kultury jamowej. In: A. Kośko, M. Potupczyk, S. Razumow (Eds) Naddniestrzańskie kompleksy cmentarzysk kurhanowych społeczności z III $i$ z pierwszej polowy II tysiqclecia $B C w$ okolicach Jampola, obwód winnicki. $Z$ badań nad pótnocno-zachodniq rubieżq osadnictwa społeczności kręgu kultur „wczesnobrazowych" strefy pontyjskiej. Badania z lat 1984-2010. Archaeologia Bimaris - Monografie 6, 351-386. Poznań.

Ivanova S.V., Toschev G.N.

2015 Late Eneolithic and Bronze Age prologue Pontic societies. Forest-steppe Middle Dniester and Prut drainage basins in the 4th/3rd-2nd millennium BC: A history of investigations. In: A. Kośko (Ed.) Podolia as a Cultural Contact Area in the 4th/3rd-2nd Millennium BC. Baltic-Pontic Studies 20: 7-39.

2015a The Middle-Dniester cultural contact area of early metal age societies. The frontier of Pontic and Baltic drainage basin in the 4th/3rd-2nd millenium BC. In: A. Kośko (Ed.) Podolia as a Cultural Contact Area in the 4th/3rd-2nd Millennium BC. Baltic-Pontic Studies 20: 406-424.

Jachimowicz K.

2015 Analiza przestrzenna kurhanów kultury grobów jamowych z okolic Jampola, Ukraina (held in the archives of Adam Mickiewicz University in Poznań).

Kashuba M.T., Kurchatov S.Y., Scherbakova T.A.

2001-2002 Kochevniki na zapadnoy granitse Velikoy stepi (po materialam kurganov u s. Mocra). Stratum plus 4: 180-252. 
Klochko V.I., Kośko A., Potupchyk M.V., Włodarczak P., Żurkiewicz D., Ivanova S.V.

2015 Tripolye (Gordineşti group), Yamnaya and Catacomb culture cemeteries, Prydnistryanske, site 1, Yampil Region, Vinnitsa Oblast: an archaeometric and chronometric description and a taxonomic and topogenetic discussion. In: A. Kośko (Ed.) Podolia as a Cultural Contact Area in the 4th/3rd-2nd Millennium BC. Baltic-Pontic Studies 20: 183-255.

Klochko V.I., Kośko A., Razumov S.M., Włodarczak P., Żurkiewicz D.

2015a Eneolithic, Yamnaya, Catacomb and Babyno culture cemeteries, Pidlisivka, barrow 1, Yampil Region, Vinnitsa Oblast: archaeometry, chronometry and taxonomy. In: A. Kośko (Ed.) Podolia as a Cultural Contact Area in the 4th/3rd-2nd Millennium BC. Baltic-Pontic Studies 20: 40-77.

Kośko A.

2011 Z badań nad kontekstem kultur wczesno brązowych strefy pontyjskiej w rozwoju społeczności środkowoeuropejskich obszaru dorzeczy Wisły w III tys. BC. In: U. Stankiewicz, A. Wawrusiewicz (Eds) Na rubieży kultur. Badania nad okresem neolitu $i$ wczesna epoka brazu, 183-194. Białystok.

Kośko A., Potupczyk M., Razumow S. (Eds)

2014 Naddniestrzańskie kompleksy cmentarzysk kurhanowych społeczności zIII $i$ z pierwszej polowy II tysiaclecia BC w okolicach Jampola, Oblast Winnica. Z badań nad pótnocno-zachodniq rubieża osadnictwa społeczności kręgu kultur ,wczesnobrazowych” strefy pontyjskiej. Badania z lat 19842010. Archaeologia Bimaris - Monografie 6. Poznań.

Kośko A., Razumov S.

2014 Cele i metody badań terenowych. In: A. Kośko, M. Potupczyk, S. Razumow (Eds) Naddniestrzańskie kompleksy cmentarzysk kurhanowych społeczności z III $i$ z pierwszej polowy II tysiaclecia BC $w$ okolicach Jampola, obwód winnicki. Z badań nad północno-zachodniq rubieża osadnictwa spoteczności kręgu kultur „wczesnobrązowych” strefy pontyjskiej. Badania z lat 1984-2010. Archaeologia Bimaris - Monografie 6, 41-44. Poznań.

Krushelnitska L.

2006 Kultura Noa na zemliakh Ukrayiny. Lviv.

Libera J.

2009 Materiały krzemienne z badań kurhanów kultury ceramiki sznurowej na Grzędzie Sokalskiej. In: J. Machnik, J. Bagińska, W. Koman, Neolityczne kurhany na Grzędzie Sokalskiej w świetle badań archeologicznych w latach 1988-2006, 279-302. Kraków. 
Litvinova L.V., Łukasik S., Żurkiewicz D., Gwizdała M., Chyleński M., Mamström H., Jakobsson M., Juras A.

2015 Anthropological description of skeletal material from the Dniester Barrow-Cemetery Complex, Yampil Region, Vinnitsa Oblast (Ukraine). In: A. Kośko (Ed.) Podolia as a Cultural Contact Area in the 4th/3rd-2nd Millennium BC. Baltic-Pontic Studies 20: 292-335.

Machnik J., Pavliv D., Petehyryč V.

2006 Recapitulation of results of the archaeological research and outline of the history of the earliest settlement on the Sambir upland (including the Strvjaž River basin) and the Drohobyč upland. In: J. Machnik (Ed.) Environment and man at the Carpathians foreland in the upper Dnister catchment from Neolithic to Early Mediaeval period, Prace Komisji Prehistorii Karpat PAU 3, 228-243. Kraków.

Manzura I.V.

2003-2004 Severnoe Prichernomore v eneolite i bronzovom veke: stupeni kolnizatsii. Stratum plus 2/2003-2004: 63-85.

2010 „Vytianutye” pogrebeniya epokhi eneolita v Karpato-Dnestrovskom Regione. Tyragetia. Serie nouă 4 (1): 35-47.

Manzura I.V., Klochko E.O, Savva E.N.

1992 Kamenskie kurgany. Kishinev.

Potemkina T.M.

2004 Osobennosti struktury sakralnogo prostranstva eneoliticheskikh kurhanov so stolbovymi konstruktsiyamy (po materialam Severnoho Prichernomoria). In: A.N. Gey (Ed.) Pamiatniki arkheologii i drevnego isskusstva Evrazii, 214-250. Moskva.

Potupczyk M., Razumow S.

2014 Zgrupowanie cmentarzysk kurhanowych w rejonie jampolskim. In: A. Kośko, M. Potupczyk, S. Razumow (Eds) Naddniestrzańskie kompleksy cmentarzysk kurhanowych społeczności z III i z pierwszej połowy II tysiąclecia BC w okolicach Jampola, obwód winnicki. Z badań nad pótnocno-zachodniq rubieża osadnictwa społeczności kręgu kultur „wczesnobrazowych" strefy pontyjskiej. Badania z lat 1984-2010. Archaeologia Bimaris - Monografie 6, 35-39. Poznań.

Rassamakin Y.Y.

1994 The Main Directions of the Development of Early Pastoral Societies of the Northern Pontic Zone: 4500-2450 BC (Pre-Yamnaya Cultures and Yamnaya Culture). In: A. Kośko (Ed.) Nomadism and Pastoralism in the Circle of Baltic-Pontic Early Agrarian Cultures: 5000-1650 BC. Baltic-Pontic Studies 2: 29-70. 
2013 From the Late Eneolithic period to the Early Bronze Age in the Black Sea steppe: what is the Pit Grave Culture (late fourth to mid-third millenium BC)? In: V. Heyd, G. Kulcsár, V. Szeverényi (Eds) Transition to the Bronze Age. Interregional interaction and socio-cultural change in the third millenium BC. Carpathian Basin and neighbouring regions, 113-138. Budapest.

\section{Razumov S.M.}

2011 Flint Artefacts of Northern Pontic Populations of the Early and Middle Bronze Age: 3200-1600 BC. Baltic-Pontic Studies 16.

Razumov S.M., Kośko A., Karnaukh E.G.

2012a Doslidzhennia kurhanu bilia s. Porohy Yampilskoho rayonu Vinyytskoy Oblasti (held in the archives of IA NANU). Kyiv.

Razumov S.M., Lysenko S.D., Kośko A.

2012b Babinskoe pogrebenie s chashey u s. Porogi na Dnestre. In: O.I. Hurzhiy et al. (Eds) Arkasivski chytannia: materialy II Mizhnarodnoyi naukowo-praktychnoyi konferentsiyi, 84-87. Mykolayiv.

Shmagliy N.M., Chernyakov I.T.

1970 Kurgany stepnoy chasti mezhdurechia Dunaya i Dnestra. Materialy po arkheologii Severnogo Prichernomoria 6. Odessa.

Simonenko A.V., Lobay B.I.

1991 Sarmaty Severo-Zapadnego Prichernomoria v I v. n.e. Kyiv.

Sudnik-Wójcikowska B., Moysienko I.I., Dembicz I., Galery H., Rowińska A., Zachwatowicz M.

2013 Kurhany na „Dzikich Polach” - dziedzictwo kultury i ostoja ukraińskiego stepu. Warszawa.

Włodarczak P.

2006 Kultura ceramiki sznurowej na Wyżynie Małopolskiej. Kraków.

Yarovoy E.V.

1978 Otchet o polevykh issledovaniakh eneoliticheskoy archeologicheskoy ekspeditsii v 1977 godu (held in the Archaeological Archives of National Museum of Archaeology and History of Moldova, No.124). Kishinev.

1985 Drevneyshie skotovodcheskie plemena yugo-zapada SSSR (klassifikatsiya pogrebalnogo obriada). Kishinev.

1990 Kurgany epokhi eneolita-bronzy Nizhnego Podnestrovia. Kishinev.

2001 Eneoliticheskie sviatilischay antropomorfnye stely Dnestrovsko-Prutskogo mezhdurechia. In: Davnia istoriya Ukrayiny i sumizhnykh rehioniv. Carpatica 13. Yuvileynyi zbirnyk na chest 70-richchia vid dnia narodzhennia prof. E.A. Balaguri, 67-77. Uzhhorod. 
Zbenovich V.G.

1974 Pozdnetripolskie plemena Severnogo Prichernomoria. Kyiv. 